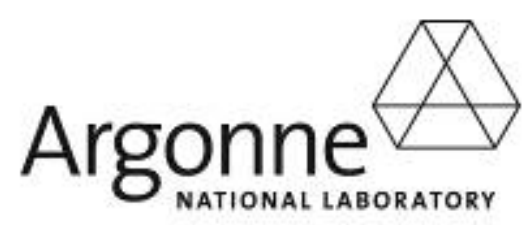

\title{
Use of Reclaimed Water for Power Plant Cooling
}

Environmental Science Division 


\begin{abstract}
About Argonne National Laboratory
Argonne is a U.S. Department of Energy laboratory managed by UChicago Argonne, LLC under contract DE-ACO2-06CH11357. The Laboratory's main facility is outside Chicago, at 9700 South Cass Avenue, Argonne, Illinois 60439. For information about Argonne, see www.anl.gov.
\end{abstract}

\title{
Availability of This Report
}

This report is available, at no cost, at http $/ /$ www.osti.gov/bridge. It is also available on paper to the U.S. Department of Energy and its contractors, for a processing fee, from:

U.S. Department of Energy

Office of Scientific and Technical Information

P.O. Box 62

Oak Ridge, TN 37831-0062

phone (865) 576-8401

fax (865) 576-5728

reports@adonis.osti.gov

\section{Disclaimer}

This report was prepared as an account of work sponsored by an agency of the United States Government. Neither the United States Government nor any agency thereot, nor UChicago Argonne, LLC, nor any of their employees or officers, makes any warranty, express or implied, or assumes any legal liability or responsibility for the accuracy, completeness, or usefulness of any information, apparatus, product, or process disclosed, or represents that its use would not infringe privately owned rights. Reference herein to any specific commercial product, process, or service by trade name, trademark, manufacturer, or otherwise, does not necessarily constitute or imply its endorsement, recommendation, or favoring by the United States Government or any agency thereof. The views and opinions of document authors expressed herein do not necessanily state or reflect those of the United States Government or any agency thereof, Argonne National Laboratory, or UChicago Argonne, LLC 


\title{
Use of Reclaimed Water for Power Plant Cooling
}

\author{
for the \\ U.S. Department of Energy \\ National Energy Technology Laboratory \\ by \\ J.A. Veil \\ Environmental Science Division, Argonne National Laboratory
}

August 2007 



\section{CONTENTS}

Chapter 1 - Introduction ..................................................................................................... 1

Power Plants Need Water ................................................................................................

Meeting Water Demands in a Water-Constrained Environment ......................................... 3

Purpose and Structure of the Report ................................................................................... 3

Chapter 2 - Database of Reclaimed Water Use for Cooling .................................................... 5

Data Collection ..............................................................................................

The Database......................................................................................................

Chapter 3 - Regulatory Considerations ………………................................................. 10

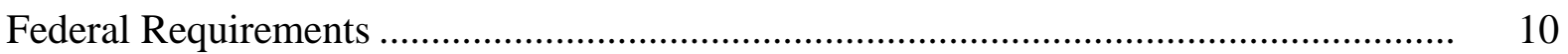

State Requirements .......................................................................................... 11

Suggested Guidelines for Using Reclaimed Water.......................................................... 15

Other Requirements .................................................................................................. 15

Chapter 4 - Treatment Requirements Associated with Using Reclaimed Water for Cooling .................................................................................................................... 17

Reclaimed Water Quality for Public Health and Environmental Protection ..................... 17

Reclaimed Water Quality for Operational Needs .............................................................. 17

Treatment of Reclaimed Water ....................................................................................... 19

Chapter 5 - The Panda Brandywine Plant .............................................................................. 22

Plant Location and Description.............................................................................. 22

Site Visit................................................................................................... 24

Chapter 6 - Findings and Conclusions ………………........................................................ 28

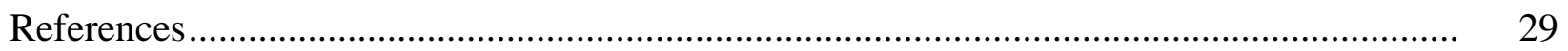

Appendix A - Database of Power Plants Using Reclaimed Water ………………………....... 35

Appendix B - Reclaimed Water Regulations for Arizona........................................................ 42

Appendix C - Reclaimed Water Regulations for California ................................................... 52

Appendix D - Reclaimed Water Regulations for Florida........................................................... 54

Appendix E - Reclaimed Water Regulations for Texas ......................................................... 58 


\section{FIGURES}

Figure 1 - Reclaimed Water Pipes and Pumps Painted Purple ......................................... 16

Figure 2 - Regional Map Showing Location of Plants................................................... 22

Figure 3 - Aerial Photo Showing Panda Brandywine Site ............................................. 23

Figure 4 - Fire Hydrant Conveying Reclaimed Water ..................................................... 25

Figure 5 - Reclaimed Water Line Entering Cooling Tower........................................... 25

Figure 6 - Reclaimed Water Lines and Cooling Tower .............................................. 26

Figure 7 - Reclaimed Water Pipe and Recirculating Pumps .......................................... 26

Figure 8 - Cooling Tower Plume........................................................................... 27

Figure 9 - Reclaimed Water Falling through Cooling Tower and Forming a Mist .............. 27

\section{TABLES}

Table 1 - Water Intensity at Thermoelectric Power Plants ............................................ 2

Table 2 - Geographic Distribution of Facilities ........................................................ 7

Table 3 - Volume Usage Distribution .................................................................... 8

Table 4 - Distribution of Facilities by Their Usage of Reclaimed Water ............................ 8

Table 5 - Distribution of Facilities by Decade in Which Power Plant Began

Using Reclaimed Water ...................................................................................... 9

Table 6 - Summary of State Water Reuse Regulations and Guidelines as of 2002 .............. 13

Table 7 - Basic Water Quality Parameters and Limiting Concentrations

for Cooling Tower Recirculating Water ............................................................... 18

Table 8 - Treatment Processes for Power Plant Cooling Water......................................... 20 


\section{Chapter 1 - Introduction}

Freshwater demands are steadily increasing throughout the United States. As its population increases, more water is needed for domestic use (drinking, cooking, cleaning, etc.) and to supply power and food. In arid parts of the country, existing freshwater supplies are not able to meet the increasing demands for water. New water users are often forced to look to alternative sources of water to meet their needs. Over the past few years, utilities in many locations, including parts of the country not traditionally water-poor (e.g., Georgia, Maryland, Massachusetts, New York, and North Carolina) have needed to reevaluate the availability of water to meet their cooling needs. This trend will only become more extreme with time. Other trends are likely to increase pressure on freshwater supplies, too. For example, as populations increase, they will require more food. This in turn will likely increase demands for water by the agricultural sector. Another example is the recent increased interest in producing biofuels. Additional water will be required to grow more crops to serve as the raw materials for biofuels and to process the raw materials into biofuels.

This report provides information about an opportunity to reuse an abundant water source treated municipal wastewater, also known as "reclaimed water" — for cooling and process water in electric generating facilities. The report was funded by the U.S. Department of Energy's (DOE’s) National Energy Technology Laboratory (NETL) Innovations for Existing Plants research program (Feeley 2005). This program initiated an energy-water research effort in 2003 that includes the availability and use of "nontraditional sources" of water for use at power plants.

This report represents a unique reference for information on the use of reclaimed water for power plant cooling. In particular, the database of reclaimed water user facilities described in Chapter 2 is the first comprehensive national effort to identify and catalog those plants that are using reclaimed water for cooling.

\section{Power Plants Need Water}

Steam electric power plants produce electricity by heating purified water to create high-pressure steam. The steam expands inside turbines, driving the generators that produce electricity. After leaving the turbines, the steam must be cooled. In the United States, nearly all steam electric plant cooling relies on water as the heat sink. Steam passes through a condenser that has multiple tubes and a large surface area. A large volume of cool water circulates through the tubes, absorbing heat from the steam. As the steam cools and condenses, the temperature of the cooling water rises.

Water-based cooling systems follow either once-through or closed-cycle designs. Once-through cooling systems withdraw large volumes of water - typically in the range of tens of millions to billions of gallons per day from a river, lake, estuary, or ocean. The water is pumped through the condenser in a single pass and returned to the same or a nearby water body. Although the water withdrawal rates are very high, most of the water is subsequently returned to the water body.

Closed-cycle cooling systems receive their cooling water from and return it to a cooling tower and basin, cooling pond, or cooling lake. Because evaporation and planned cooling tower 
blowdown (periodic discharges of portions of the recirculating water to remove build up of solids and other undesirable constituents) remove cooling water from the evaporative system, regular additions of "makeup" cooling water are needed. Makeup volumes are much lower than daily once-through volumes and may range from hundreds of thousands to millions of gallons per day. Although makeup water withdrawal volume is lower, virtually all of the makeup water is consumed without being returned to the water body.

The steam electric power industry withdraws and consumes vast quantities of water each day for cooling. The U.S. Geological Survey estimates that in 2000 the power industry withdrew 136 billion gallons per day of freshwater for cooling (Hutson et al. 2004). This amount approximates the daily volume of freshwater withdrawn by the agriculture sector for irrigation. Much of the water withdrawn for cooling is returned to surface water bodies, while most of the irrigation water is consumed.

Table 1 (based on DOE 2006) shows the water intensities, or water withdrawal rates, for different fuel types and different cooling systems. The rates are expressed as gallons per megawatt-hour (gal/MWh).

Table 1 - Water Intensity at Thermoelectric Power Plants

\begin{tabular}{|l|l|l|l|}
\hline & & \multicolumn{3}{|l|}{ Water Intensity (gal/MWh) } \\
\hline Plant Type & Cooling System & Withdrawal & Consumption \\
\hline Fossil/biomass/waste & Once-through & $20,000-50,000$ & $\sim 300$ \\
\hline & Cooling tower & $300-600$ & $300-480$ \\
\hline Nuclear & Cooling pond & $500-600$ & $\sim 480$ \\
\hline & Once-through & $25,000-60,000$ & $\sim 400$ \\
\hline & Cooling tower & $500-1,100$ & $400-720$ \\
\hline Geothermal steam & Cooling pond & $800-1,100$ & $\sim 720$ \\
\hline $\begin{array}{l}\text { Natural gas, combined } \\
\text { cycle }\end{array}$ & Cooling tower & $\sim 2,000$ & $\sim 1,400$ \\
\hline & Once-through & $7,500-20,000$ & 100 \\
\hline $\begin{array}{l}\text { Coal, integrated } \\
\text { gasification combined } \\
\text { cycle }\end{array}$ & Cooling tower & $\sim 230$ & $\sim 180$ \\
\hline
\end{tabular}

Source: DOE (2006).

Virtually all new steam electric units built since the mid-1970s have used closed-cycle cooling, and most of those have used cooling towers. As the water intensity rates from Table 1 show, cooling towers at fossil-fueled plants would require 300-600 gal/MWh, while those at nuclear plants would require 500-1,100 gal/MWh, those at natural gas combined-cycle plants would require about $230 \mathrm{gal} / \mathrm{MWh}$, and those at integrated gasification combined-cycle coal plants would require about $250 \mathrm{gal} / \mathrm{MWh}$. Irrespective of the fuel type, steam electric power plants require a great deal of water. 


\section{Meeting Water Demands in a Water-Constrained Environment}

NETL has funded projects to evaluate several types of alternative water sources. Argonne National Laboratory evaluated using mine pool water from underground coal mines (Veil et al. 2003; Veil and Puder 2006). Argonne identified one large nuclear plant in southeastern Pennsylvania and several smaller plants in the anthracite coal mining section of Pennsylvania that are currently using mine pool water for cooling. West Virginia University has conducted a series of projects that assess the feasibility of using underground mine water in the northern West Virginia and southwestern Pennsylvania regions as sources of cooling water for power plants (West Virginia Water Research Institute 2004).

In 2003, NETL funded a group of researchers led by the Electric Power Research Institute to evaluate the feasibility of using coal bed methane (CBM) produced water to meet up to $25 \%$ of the cooling water needs at the San Juan Generating Station in northwestern New Mexico. The plant requires about 20 million gallons per day (MGD) of makeup water to replace water lost to evaporation or blowdown. The researchers prepared a series of reports, all of which are available at http://www.netl.doe.gov/technologies/coalpower/ewr/water/pp-mgmt/epri.html. According to those researchers, the economics of using produced water at that specific plant do not appear favorable. Therefore, the utility is not moving forward with implementation.

Reclaimed water is another large alternative source of water being used throughout the United States. Many studies have reported on reclaimed water use for irrigation, fire protection, wildlife habitat enhancement, and a variety of industrial uses. The U.S. Environmental Protection Agency (EPA) has issued several reports on reclaimed water and water reuse, the most comprehensive of which was completed in 2004. EPA (2004) documents numerous examples of reclaimed water reuse, including some involving cooling water at power plants.

Reuse of water, including reclaimed water, is the central focus of a national association, the WateReuse Association (http://www.watereuse.org). The organization sponsors national conferences and meetings that provide information on many aspects of water reuse including reclaimed water. The association recently compiled a national database of water reuse facilities (http://www.watereuse.org/ndwrf/index.htm). At the time this report was prepared, the database was not configured to permit searches relating to reclaimed water use for cooling at power plants, although that capability may be added later.

\section{$\underline{\text { Purpose and Structure of the Report }}$}

The purpose of this report is to present information on the actual use of reclaimed water for cooling or other purposes at power plants. As traditional freshwater supplies become less available for power plant uses, power companies will need to look to alternative water sources. Unlike mine pool water or produced water, reclaimed water is available in communities throughout the country. Although reclaimed water has been used for several decades at some power plants, no comprehensive database of power facilities using reclaimed water has been developed. Chapter 2 of this report describes the first national database to fill that void. Chapter 3 reviews the types of regulatory requirements that federal and state agencies have imposed to govern reuse of reclaimed water. Chapter 4 discusses the types of additional 
treatment that may be required before a power plant can use reclaimed water. Chapter 5 describes a site visit to the Panda-Brandywine power plant located near Washington, DC. The plant uses reclaimed water as cooling tower makeup. Chapter 6 offers summary findings and conclusions. After the list of references, there are 5 appendices. Appendix A is the complete database of reclaimed water users. The other four appendices provide excerpts from the reclaimed water regulations of four key states. 


\section{Chapter 2 - Database of Reclaimed Water Use for Cooling}

\section{$\underline{\text { Data Collection }}$}

At the onset of the project, contacts were made with government agencies and organizations representing both the municipal wastewater side (the generators) and the electric power industry (the users). Contacts were initially made with the following organizations:

- EPA,

- Selected state environmental protection agencies that regulate wastewater discharges,

- Water Environment Federation (WEF),

- WateReuse Association,

- National Association of Clean Water Agencies (NACWA),

- Association of State and Interstate Water Pollution Control Administrators (ASIWPCA),

- $\quad$ Electric Power Research Institute (EPRI),

- Edison Electric Institute (EEI), and

- Utility Water Act Group (UWAG).

It soon became apparent that, while the agencies and organizations had interest in either reclaimed water or alternative cooling water or both, none of them was tracking the universe of facilities that actually use reclaimed water for cooling at power plants. Although different sources provided isolated references to reports, magazine articles, Web sites, or personal anecdotes, no substantial lists or databases could be found.

The database ultimately was developed by conducting extensive research on the Internet, followed by numerous phone calls to track down and confirm details. Several sources of information (listed below) provided starting points. In many cases, more information was available from the municipalities generating the reclaimed water than from the power companies using the water.

The Internet searches were carried out by using Google (http://www.google.com) or the search boxes of agency or company Web sites. In some cases, the desired information was obtained quickly. More commonly, several combinations of search terms were tried, and many of the resulting suggested sites were scanned for relevant information. It was not uncommon to spend several hours tracking down information relating to a single site. Likewise, some phone contacts were accomplished efficiently on the first call, although most involved numerous attempts and transfers to contact the appropriate knowledgeable person. In some cases, answers to questions were obtained from respondents only after repeated callbacks.

- The DOE's Energy Information Administration (EIA) compiles a national database of steam electric plant operation and design data. The latest version of this database is called the “767 Data Files" (EIA 2005). One of the data fields in the database is "Cooling Water Source," which provides the name of the river, lake, or other water body used as the water source for more than 1,500 generating units. In some cases, the source is listed as a municipality or a sewer authority. 
- EEI published a report of the environmental characteristics of U.S. power plants more than a decade ago (EEI 1996). Included with the information listed for each plant is the source of the water used for cooling. Although many of the plants in the EEI report have been decommissioned or have changed corporate ownership, the report still provided insights as to which plants were using municipal wastewater in 1996.

The examples discovered through EIA (2005) and EEI (1996) were carefully researched to learn whether the municipalities were providing reclaimed water or municipal drinking water and whether the water was currently being used by the power plants for cooling.

- EPA (2004) contained references to some power plants that were using reclaimed water, although the report included only minimal details on each facility.

- The Maryland Power Plant Research Program (MPPRP) prepared an environmental review report as part of the siting of the Panda-Brandywine power plant built in Maryland during the 1990s (MPPRP 1997). The plant planned to use reclaimed water from a nearby wastewater treatment plant (WWTP). Consequently, the report offered some other examples in which reclaimed water was used for cooling.

All of the examples found in EPA (2004) and MPPRP (1997) were carefully researched to learn whether reclaimed water is currently being used by the power plants for cooling.

- At least two states (California and Florida) have compiled information on the wastewater treatment plants that generate reclaimed water along with the general ways in which the water is used. The California State Water Resources Board (CSWRB 2000) published the last California list in 2000. The list does not identify the actual users of the water. Also the fact that cooling is listed as the type of reuse does not necessarily mean that the water is used for power plant cooling. Many examples were found in which the reclaimed water was sent to schools, businesses, or commercial facilities for cooling the air in the buildings. Although these are good ways to use reclaimed water, they are outside of the scope of this report.

- Florida was not able to provide a published list. However, representatives from the Water Reuse Program in the Florida Department of Environmental Protection (DEP) shared examples from their personal experience and later provided a spreadsheet of other potential candidate facilities.

All of the potential facilities identified through CSWRB (2000) and from the Florida DEP contacts were carefully researched to learn whether reclaimed water is currently being used by the power plants for cooling.

References to additional examples were discovered during the data collection process. Each of these was researched to learn whether reclaimed water is currently being used by the power plant for cooling. 


\section{The Database}

The full database of 57 facilities is attached as Appendix A. Although some of these facilities have been well documented in the literature, many were discovered only by conducting detailed detective work during the Internet search process. It is quite likely that some other power plants not identified in the database are also using reclaimed water for cooling tower makeup.

Nevertheless, the database presented in this report probably captures most of the U.S. examples.

Other national databases, like the EIA database described earlier, provide extensive information on the properties of power plants. The reclaimed water user database developed for this project includes only those fields that are relevant to the use of reclaimed water. The database includes information on the name and location of the wastewater treatment facility that generates the reclaimed water, the name and location of the power plant that uses the reclaimed water, how the water is used at the plant, the year in which use of reclaimed water started, other comments, and references for each entry. Tables $2-5$ provide summary information from the database.

Table 2 shows the distribution of facilities by state. The states with the largest numbers of facilities using reclaimed water are Florida, California, Texas, and Arizona. All of these states have dealt with freshwater shortages for many years. The use of reclaimed water in these locations is a direct response to those shortages. However, the use of reclaimed water is occurring throughout the country. Some examples are found in states that traditionally have been considered to have ample water supplies (e.g., Massachusetts, Maryland, Mississippi, New Hampshire, New Jersey, Pennsylvania, and Wisconsin).

Table 2 - Geographic Distribution of Facilities

\begin{tabular}{|c|c|}
\hline $\begin{array}{c}\text { State in Which Power Plant and } \\
\text { Wastewater Treatment Plant Are Located }\end{array}$ & $\begin{array}{c}\text { Number of Power Plants Using Reclaimed } \\
\text { Water }\end{array}$ \\
\hline AZ & 3 \\
\hline CA & 13 \\
\hline CO & 1 \\
\hline FL & 17 \\
\hline IA & 1 \\
\hline KS & 1 \\
\hline MA & 3 \\
\hline MD & 2 \\
\hline NS & 1 \\
\hline NJ & 1 \\
\hline NM & 2 \\
\hline NV & 1 \\
\hline PA & 2 \\
\hline TX & 1 \\
\hline WI & 7 \\
\hline & 1 \\
\hline
\end{tabular}


Table 3 shows the volumes of reclaimed water used by the facilities as distributed into several volume categories. The data are well distributed and range from less than 0.1 MGD to as high as 55 MGD. Many facilities use varying rates on a seasonal basis, as the power plants' capacity factor shifts to meet power demand.

Table 3 - Volume Usage Distribution

\begin{tabular}{|c|c|}
\hline Volume of Reclaimed Water Used $^{\mathbf{a}}$ (MGD) & Number of Facilities \\
\hline$<0.1$ & 6 \\
\hline 0.1 to 0.5 & 10 \\
\hline 0.51 to 1.0 & 12 \\
\hline 1.01 to 5.0 & 15 \\
\hline 5.01 to 10.0 & 6 \\
\hline$>10.0$ & 5 \\
\hline
\end{tabular}

${ }^{\mathrm{a}}$ When the volume was provided as a range, the upper end of the range was used for this table.

The largest reclaimed water user identified in the study is the Bethlehem Steel Sparrows Point steel mill in Baltimore. Although the mill did not use reclaimed water for cooling a powergenerating unit, ${ }^{1}$ it is included in the database for historical purposes. For many years, the plant used about 100 MGD of reclaimed water from the Back River Wastewater Treatment Plant. Bethlehem Steel was sold under bankruptcy proceedings in 2003. The steel mill now operates at a fraction of its historic capacity and uses considerably less reclaimed water. Recent inquiries made to the steel company and to the Maryland Department of the Environment failed to yield any current reclaimed water use information.

Table 4 shows the purposes for which the reclaimed water is used at the power plants. Most of the plants use the reclaimed water as cooling tower makeup. Other uses include supplementing cooling ponds or as air scrubbers or boiler feed water and as a water source to maintain underground pressure in geothermal fields in northern California.

Table 4 - Distribution of Facilities by Their Usage of Reclaimed Water

\begin{tabular}{|c|c|}
\hline Usage of Reclaimed Water & Number of Facilities \\
\hline Cooling tower makeup & 46 \\
\hline Cooling ponds & 2 \\
\hline Air scrubbers & 2 \\
\hline Injected to increase pressure at geothermal fields & 2 \\
\hline Boiler feed water & 1 \\
\hline Cooling tower makeup and scrubber water & 1 \\
\hline
\end{tabular}

\footnotetext{
${ }^{1}$ The Sparrows Point mill operated its own steam electric power plant onsite. However, the power plant used brackish water from the nearby Baltimore Harbor for cooling the power plant. The reclaimed water was used for contact cooling of steel and for other process purposes in the mill.
} 
Table 5 shows the decade in which power facilities began using reclaimed water. Most power plants in the database began using reclaimed water in the 1990s and since 2000. Two of the facilities are planning to begin using reclaimed water later in 2007 or in 2008. The oldest reported usage of reclaimed water was found in Burbank, California. The Olive and original Magnolia plants started using reclaimed water in 1967. The Lake One plant started later. The original Magnolia plant is now out of service, while the other two plants are on intermittent stand-by service.

Table 5 - Distribution of Facilities by Decade in Which Power Plant Began Using Reclaimed Water

\begin{tabular}{|c|c|}
\hline $\begin{array}{c}\text { Decade in Which Power Plant Began Using } \\
\text { Reclaimed Water }\end{array}$ & Number of Facilities \\
\hline 1960 to 1969 & 2 \\
\hline 1970 to 1979 & 3 \\
\hline 1980 to 1989 & 8 \\
\hline 1990 to 1999 & 18 \\
\hline After 2000 & 19 \\
\hline
\end{tabular}




\section{Chapter 3 - Regulatory Considerations}

Use of reclaimed water for cooling involves several sets of regulatory requirements. The regulations are discussed in the following sections. Readers are referred to EPA (2004) for a more detailed discussion of the national and state legal and regulatory requirements associated with the full spectrum of reuse of reclaimed water for various purposes.

\section{Federal Requirements}

The Clean Water Act (CWA) requires that all discharges of pollutants to surface waters (streams, rivers, lakes, bays, and oceans) must be authorized by a permit issued under the National Pollutant Discharge Elimination System (NPDES) program. Under the CWA, the EPA has the authority to implement the NPDES program. The EPA may authorize states - as well as territories and tribes - to implement all or parts of the national program. Once approved, a state would gain the authority to issue permits and administer the program. In the absence of state assumption of NPDES authority, the EPA operates the NPDES program in direct implementation.

Municipal wastewater treatment facilities must obtain an NPDES permit before discharging treated wastewater. NPDES permits contain discharge limits that are based on two separate types of evaluation. The first includes "technology-based" limits that reflect the level of treatment that EPA believes to be readily available and affordable. For municipal wastewater, the national minimum technology-based discharge standard for municipal wastewater is referred to as "secondary treatment," which is defined at 40 CFR 133.102 (see below). The secondary treatment regulation uses the terms five-day biochemical oxygen demand $\left(\mathrm{BOD}_{5}\right)$, total suspended solids (SS, often expressed as TSS), and five-day carbonaceous biochemical oxygen demand $\left(\mathrm{CBOD}_{5}\right)$.

Sec. 133.102 Secondary treatment. The following paragraphs describe the minimum level of effluent quality attainable by secondary treatment in terms of the parameters-$\mathrm{BOD}_{5}$, SS and $\mathrm{pH}$. All requirements for each parameter shall be achieved except as provided for in Sec. 133.103 and 133.105. [Note that these two sections refer to alternate ways of meeting secondary standards]

(a) BOD5.

(1) The 30-day average shall not exceed $30 \mathrm{mg} / \mathrm{l}$.

(2) The 7-day average shall not exceed $45 \mathrm{mg} / \mathrm{l}$.

(3) The 30-day average percent removal shall not be less than 85 percent

(4) At the option of the NPDES permitting authority, in lieu of the parameter $\mathrm{BOD}_{5}$ and the levels of the effluent quality specified in paragraphs (a)(1), (a)(2) and (a)(3), the parameter $C B O D_{5}$ may be substituted with the following levels of the $\mathrm{CBOD}_{5}$ effluent quality provided:

(i) The 30-day average shall not exceed $25 \mathrm{mg} / \mathrm{l}$.

(ii) The 7-day average shall not exceed $40 \mathrm{mg} / \mathrm{l}$.

(iii) The 30-day average percent removal shall not be less than 85 percent.

(b) $S S$.

(1) The 30-day average shall not exceed $30 \mathrm{mg} / \mathrm{l}$. 
(2) The 7-day average shall not exceed $45 \mathrm{mg} / \mathrm{l}$. (c) $\mathrm{pH}$.

(3) The 30-day average percent removal shall not be less than 85 percent.

The effluent values for $\mathrm{pH}$ shall be maintained within the limits of 6.0 to 9.0 unless the publicly owned treatment works demonstrates that:

(1) Inorganic chemicals are not added to the waste stream as part of the treatment process; and

(2) contributions from industrial sources do not cause the $\mathrm{pH}$ of the effluent to be less than 6.0 or greater than 9.0 .

The second type of NPDES permit limits are "water quality-based" limits that consider the states' water quality standards and the available dilution in the receiving water body. Water quality limits may be set on metals, organic compounds, nutrients, whole effluent toxicity, or other parameters. Of particular concern to reclaimed water are the levels of bacteria and other microbial pathogens that could potentially be released to the atmosphere through a cooling tower plume. NPDES permits for municipal wastewater discharges typically include limits for microbial pathogens and/or controls for disinfection. However, these limits are not based on any national regulation; rather, they are written to reflect each state's regulations and policies.

Because reclaimed water intrinsically is treated municipal wastewater, it must meet secondary standards, at a minimum. Beyond this basic level of treatment, there are no other federal requirements specifically relating to reclaimed water. Federal requirements are not relevant to the transfer of water from the wastewater treatment plant to the power plant, nor do they control how the power plant uses the water. However, if the power plant were to discharge some of the reclaimed water or cooling tower blowdown resulting from reclaimed water use to surface waters, the plant would need an NPDES permit. Many states, on the other hand, do have programs and regulations that specifically address reclaimed water. These are discussed in the following section.

\section{$\underline{\text { State Requirements }}$}

EPA (2004) includes the results of a survey of all 50 states to identify the types of water reuse requirements in place as of November 2002. Although some of the state regulatory information may be outdated now, the report remains the most comprehensive resource available for general water reuse information. Table 6, which is reproduced from EPA (2004), provides an overview of 2002-vintage water reuse regulations and guidelines by state and by reuse category. The table identifies those states that have regulations, those with guidelines, and those states that do not have either. Regulations refer to actual rules that have been enacted and are enforceable by government agencies. Guidelines, on the other hand, are generally not enforceable but can be used in the development of a reuse program or for exercise of agency discretion.

State requirements typically consider the probable degree of public exposure to reclaimed water. In circumstances where public exposure is unlimited, reclaimed water must be highly treated. In addition to the federal secondary standards, states may require more stringent BOD and TSS standards. To control microbial pathogens, states usually establish limits on fecal or total coliform bacteria and may require that the wastewater be filtered before it can be reused as 
reclaimed water. States also frequently impose turbidity standards to ensure that the treatment systems are working properly. Chlorine is the most commonly used disinfectant. Some plants use ultraviolet radiation, ozone, or other halogenated compounds. If the disinfectant creates corrosive conditions (e.g., chlorine in some applications), operators may dechlorinate prior to use.

Table 6 indicates that only nine states had regulations or requirements for industrial reuse activities. These are California, Florida, Hawaii, New Jersey, North Carolina, Oregon, Texas, Utah, and Washington. Of these, only California, Florida, New Jersey, and Texas are represented in the reclaimed water user database described in Chapter 2. Consequently, the following discussion of state requirements focuses on those four states plus Arizona, which is home to several power plants that use reclaimed water. Additional information on state regulatory requirements for water reuse in general can be found at http://www.watereuse.org/regulatory.htm.

Arizona: The Arizona Department of Environmental Quality developed regulations that apply to wastewater treatment facilities supplying reclaimed water and to the sites where water is applied or used. A Reclaimed Water Individual Permit or Reclaimed Water General Permit is required if you are an owner or operator of a sewage treatment facility that generates reclaimed water for direct reuse or are an end user. The regulations describe several classes of reclaimed water and the types of permits required for each class. The full regulations are found in Appendix B.

Of interest to the subject of this report is Regulation 9-18-9-704 G - Prohibited Activities. Item 2.c. indicates that "providing or using reclaimed water for any of the following activities: ... c. Direct reuse for evaporative cooling or misting" is prohibited. This raises the question of how a power plant can use reclaimed water for cooling. The Reclaimed Water Office at the Arizona Department of Environmental Quality provided the answer (Mullins 2007). Regulation R-18-9701 - Definitions defines "direct reuse" as: "the beneficial use of reclaimed water for a purpose allowed by this Article. The following is not a direct reuse of reclaimed water:
a. The use of water subsequent to its discharge under the conditions of a National Pollutant Discharge Elimination System permit;
$b$. The use of water subsequent to discharge under the conditions of an Aquifer Protection Permit issued under 18 A.A.C. 9, Articles 1 through 3; or
$c$. The use of industrial wastewater or reclaimed water, or both, in a workplace subject to a federal program that protects workers from workplace exposures."

According to Ms. Mullins, if the power plant has a worker safety program in place (e.g., an Occupational Safety and Health program), item $c$ is triggered, and the reuse activity is no longer considered a direct reuse. A worker safety program that encompasses possible contact with municipal wastewater would most likely include immunizations and training. Having passed that hurdle, the power plant would not need a permit for the reuse activity. Conceivably, the power plant could also meet the terms of items $a$ and $b$ (Mullins 2007). 
Table 6 - Summary of State Water Reuse Regulations and Guidelines as of 2002

\begin{tabular}{|c|c|c|c|c|c|c|c|c|c|c|}
\hline 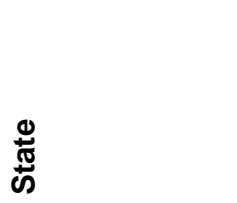 & 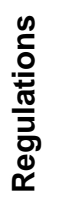 & $\begin{array}{l}0 \\
\frac{0}{0} \\
\frac{\pi}{0} \\
\frac{0}{3} \\
0\end{array}$ & 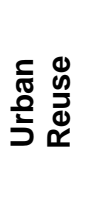 & 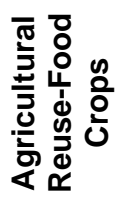 & 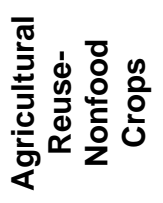 & 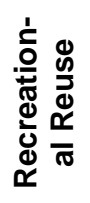 & 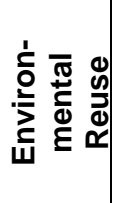 & 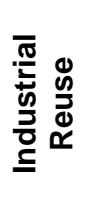 & 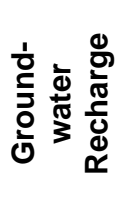 & 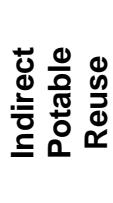 \\
\hline Alabama & & $\mathrm{X}$ & $\mathrm{X}$ & & $\mathrm{X}$ & & & & & \\
\hline Alaska & $X$ & & & & $\mathrm{X}$ & & & & & \\
\hline Arizona & $\mathrm{X}$ & & $\mathrm{X}$ & $X$ & $X$ & $\mathrm{X}$ & & & & \\
\hline Arkansas & & $\mathrm{X}$ & $\mathrm{X}$ & $\mathrm{X}$ & $\mathrm{X}$ & & & & & \\
\hline California & $\mathrm{X}$ & & $\mathrm{X}$ & $\mathrm{X}$ & $\mathrm{X}$ & $\mathrm{X}$ & & $\mathrm{X}$ & $\mathrm{X}$ & $\mathrm{X}$ \\
\hline Colorado & $\mathrm{X}$ & & $\mathrm{X}$ & $\mathrm{X}$ & $\mathrm{X}$ & $\mathrm{X}$ & & & & \\
\hline \multicolumn{11}{|l|}{ Connecticut } \\
\hline Delaware & $\mathrm{X}$ & & $\mathrm{X}$ & & $\mathrm{X}$ & & & & & \\
\hline Florida & $\mathrm{X}$ & & $\mathrm{X}$ & $\mathrm{X}$ & $\mathrm{X}$ & & $\mathrm{X}$ & $\mathrm{X}$ & $\mathrm{X}$ & $\mathrm{X}$ \\
\hline Georgia & & $\mathrm{X}$ & $\mathrm{X}$ & & $X$ & & & & & \\
\hline Hawaii & & $X$ & $\mathrm{X}$ & $\mathrm{X}$ & $\mathrm{X}$ & $\mathrm{X}$ & & $\mathrm{X}$ & $\mathrm{X}$ & $\mathrm{X}$ \\
\hline Idaho & $\mathrm{X}$ & & $\mathrm{X}$ & $\mathrm{X}$ & $\mathrm{X}$ & & & & & \\
\hline Illinois & $\mathrm{X}$ & & $\mathrm{X}$ & & $\mathrm{X}$ & & & & & \\
\hline Indiana & $X$ & & $X$ & $x$ & $X$ & & & & & \\
\hline Iowa & $\mathrm{X}$ & & $\mathrm{X}$ & & $\mathrm{X}$ & & & & & \\
\hline Kansas & & $\mathrm{X}$ & $\mathrm{X}$ & $\mathrm{X}$ & $\mathrm{X}$ & & & & & \\
\hline \multicolumn{11}{|l|}{ Kentucky } \\
\hline \multicolumn{11}{|l|}{ Louisiana } \\
\hline \multicolumn{11}{|l|}{ Maine } \\
\hline Maryland & & $X$ & $\mathrm{X}$ & & $\mathrm{X}$ & & & & & \\
\hline Massachusetts & & $\mathrm{X}$ & $\mathrm{X}$ & & $\mathrm{X}$ & & & & $x$ & $\mathrm{X}$ \\
\hline Michigan & $\mathrm{X}$ & & & $\mathrm{X}$ & $\mathrm{X}$ & & & & & \\
\hline \multicolumn{11}{|l|}{ Minnesota } \\
\hline \multicolumn{11}{|l|}{ Mississippi } \\
\hline Missouri & $\mathrm{X}$ & & $\mathrm{X}$ & & $\mathrm{X}$ & & & & & \\
\hline Montana & $\mathrm{X}$ & & $\mathrm{X}$ & $\mathrm{X}$ & $\mathrm{X}$ & & & & & \\
\hline Nebraska & $\mathrm{X}$ & & $\mathrm{X}$ & & $\mathrm{X}$ & & & & & \\
\hline Nevada & $\mathrm{X}$ & & $\mathrm{X}$ & $\mathrm{X}$ & $\mathrm{X}$ & $X$ & & & & \\
\hline \multicolumn{11}{|l|}{ New Hampshire } \\
\hline New Jersey & & $X$ & $\mathrm{X}$ & $X$ & $\mathrm{X}$ & & & $\mathrm{X}$ & & \\
\hline New Mexico & & $\mathrm{X}$ & $\mathrm{X}$ & $\mathrm{X}$ & $\mathrm{X}$ & & & & & \\
\hline New York & & $X$ & & & $X$ & & & & & \\
\hline North Carolina & $\mathrm{X}$ & & $\mathrm{X}$ & & & & & $\mathrm{X}$ & & \\
\hline North Dakota & & $\mathrm{X}$ & $\mathrm{X}$ & & $\mathrm{X}$ & & & & & \\
\hline Ohio & & $\mathrm{X}$ & $\mathrm{X}$ & & $\mathrm{X}$ & & & & & \\
\hline Oklahoma & $\mathrm{X}$ & & $\mathrm{X}$ & $\mathrm{X}$ & $\mathrm{X}$ & & & & & \\
\hline Oregon & $\mathrm{X}$ & & $\mathrm{X}$ & $\mathrm{X}$ & $\mathrm{X}$ & $\mathrm{X}$ & & $\mathrm{X}$ & & \\
\hline Pennsylvania & & $\mathrm{X}$ & & & $\mathrm{X}$ & & & & & \\
\hline \multicolumn{11}{|l|}{ Rhode Island } \\
\hline South Carolina & $\mathrm{X}$ & & $\mathrm{X}$ & & $\mathrm{X}$ & & & & & \\
\hline South Dakota & & $\mathrm{X}$ & $\mathrm{X}$ & & $\mathrm{X}$ & & $\mathrm{X}$ & & & \\
\hline Tennessee & $\mathrm{X}$ & & $\mathrm{X}$ & & $\mathrm{X}$ & & & & & \\
\hline Texas & $\mathrm{X}$ & & $\mathrm{X}$ & $\mathrm{X}$ & $\mathrm{X}$ & $\mathrm{X}$ & & $\mathrm{X}$ & & \\
\hline Utah & $\mathrm{X}$ & & $\mathrm{X}$ & $x$ & $\mathrm{X}$ & $\mathrm{X}$ & & $x$ & & \\
\hline Vermont & $\mathrm{X}$ & & & & $\mathrm{X}$ & & & & & \\
\hline \multicolumn{11}{|l|}{ Virginia } \\
\hline Washington & & $X$ & $\mathrm{X}$ & $x$ & $\mathrm{X}$ & $x$ & $x$ & $x$ & $\mathrm{X}$ & $\mathrm{X}$ \\
\hline West Virginia & $X$ & & & $\mathrm{X}$ & $X$ & & & & & \\
\hline Wisconsin & $X$ & & & & $X$ & & & & & \\
\hline Wyoming & $X$ & & $\mathrm{X}$ & $\mathrm{X}$ & $\mathrm{X}$ & & & & & \\
\hline
\end{tabular}

Source: EPA (2004). 
California: The California Department of Heath Services adopted regulations concerning the use of recycled water. These are found at Title 22 (Social Security), Division 4 (Environmental Health), Chapter 3 (Water Recycling Criteria). Relevant sections of these regulations are shown in Appendix C. The key points are described in the next paragraph.

California allows the use of reclaimed water for cooling water. Separate requirements apply to cooling systems that create a mist or do not create a mist. Cooling towers create a mist or vapor plume; therefore, use for cooling tower makeup would follow the requirements for uses that create a mist. Reclaimed water used for cooling tower makeup must be treated to tertiary standards. The term "tertiary standards" is a generic expression that includes treatment beyond secondary treatment. It may be defined differently by different jurisdictions. In the California regulations, "disinfected tertiary recycled water" means a filtered and subsequently disinfected wastewater that meets the criteria shown in regulation 60301.230 (see Appendix C). The reclaimed water must be sampled daily for total coliform bacteria and continuously for turbidity. Cooling towers that use reclaimed water for makeup must employ drift eliminators and must treat the recirculating cooling water system with chlorine or other biocide to control microorganisms.

Florida: The Florida Department of Environmental Protection developed regulations for using reclaimed water. These are found at Chapter 62-610, Reuse of Reclaimed Water and Land Application. The portions of the regulations relating to reuse for cooling (62-610.668) are shown in Appendix D. The key points are described in the next paragraph. The agency also devoted a part of its Web site to water reuse (http://www.dep.state.fl.us/water/reuse/).

Florida allows the use of reclaimed water for cooling water for once-through cooling and for open cooling towers. Different requirements apply to the two types of cooling systems. The major requirements for use in cooling towers are summarized below. Reclaimed water must be treated to secondary treatment levels and must include filtration and high-level disinfection. The reclaimed water shall not contain more than 5.0 milligrams per liter of suspended solids before the application of the disinfectant. Monitoring is required for Giardia and Cryptosporidium every two years. The reclaimed water should be monitored continuously for turbidity and chlorine or other disinfectants. A 300 -foot setback distance shall be provided from the cooling tower that receives reclaimed water to the site property line. The cooling tower shall be designed and operated to minimize aerosol drift to areas beyond the site property line that are accessible to the public.

New Jersey: The New Jersey Department of Environmental Protection does not have specific regulations for reusing reclaimed water. However, the agency has published a technical manual for reclaimed water for beneficial reuse (RWBR) (NJDEP 2005). The agency devoted a part of its Web site to water reuse (http://www.state.nj.us/dep/dwq/reuseff.htm).

Some of the key points from the technical manual are described below. Industrial RWBR involves the use of reclaimed water in industrial applications such as cooling water and/or washing operations. The uniqueness of each industrial reuse application makes it impossible to establish specific treatment standards for this general category of reuse. Prior to implementation, 
all industrial reuse systems require a case-by-case review by the Department. Other requirements include submission of Standard Operations Procedures that ensure proper material handling and a User/Supplier Agreement Annual Usage Report. Worker contact with RWBR must be limited to individuals who have received specialized training to deal with the RWBR systems. Additional requirements depend on the application.

Texas: The Texas Commission on Environmental Quality developed regulations for using reclaimed water. These are found at Title 30 Texas Administrative Code Chapter 210 - Use of Reclaimed Water. The portion of the regulations relating to reuse for cooling (210.22, 210.3234) are shown in Appendix E. The key points are described in the next paragraph.

The water must meet standards for $\mathrm{BOD}_{5}$ and fecal coliform. Sampling must be conducted once per week. There may be special requirements for use for cooling towers which produces significant aerosols adjacent to public access areas.

\section{$\underline{\text { Suggested Guidelines for Using Reclaimed Water }}$}

EPA (2004) includes suggested guidelines for reusing treated municipal wastewater in various applications. The portions of those guidelines relating to using reclaimed water for cooling are listed below.

- The minimum treatment requirements include secondary treatment, disinfection, and possible chemical coagulation and filtration, if needed. Additional treatment may be performed by the user to prevent scaling, corrosion, biological growth, fouling, and foaming.

- The reclaimed water should contain $<30 \mathrm{mg} / \mathrm{L}$ of BOD and TSS, $<200$ fecal coliform/100 milliliters (ml), a minimum of $1 \mathrm{mg} / \mathrm{L}$ residual chlorine, and a $\mathrm{pH}$ range of 6.0-9.0.

- Windblown spray should not reach areas accessible to workers or the public. This requirement can be met by providing a setback distance of 90 meters. The setback may be reduced or eliminated if a high level of disinfection is provided.

\section{Other Requirements}

In addition to federal and state regulatory requirements, local or regional governments or authorities may impose their own ordinances or regulations relating to public health or environmental conditions. These requirements are not discussed in this report, but interested readers are advised to check with local governments or authorities.

One other requirement worth noting relates to marking and identification of reclaimed water systems. The general standard is to paint any pipes, valves, pumps, and other components that convey reclaimed water a bright purple color to distinguish them from other types of water. Figure 1 shows reclaimed water pipes and pumps at the Panda-Brandywine power plant painted purple. Additional photos can be seen in Chapter 5. 
Figure 1 - Reclaimed Water Pipes and Pumps Painted Purple (Source: Veil 2007)

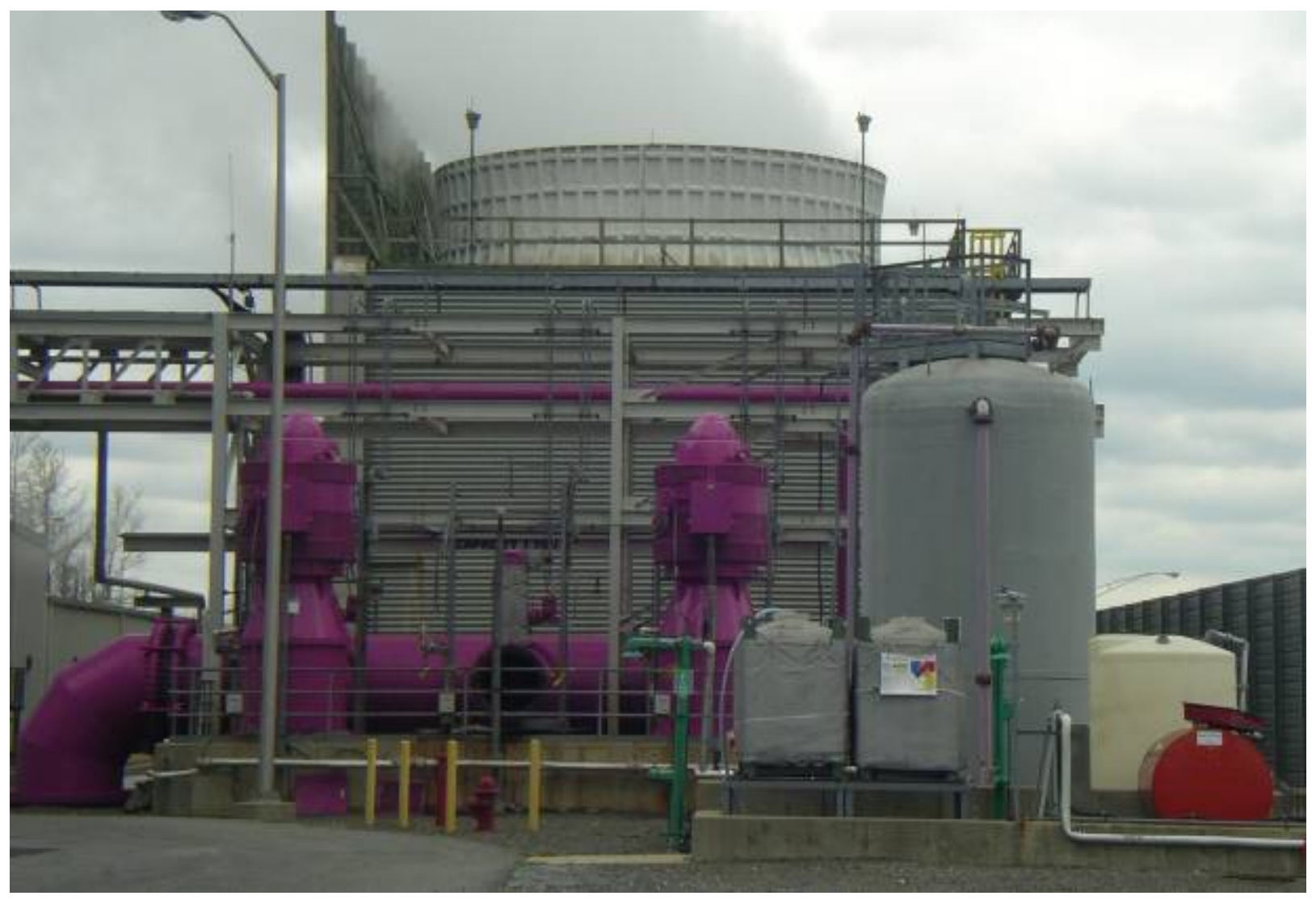




\title{
Chapter 4 - Treatment Requirements Associated with Using Reclaimed Water for Cooling
}

\author{
Reclaimed Water Quality for Public Health and Environmental Protection
}

The previous chapter described the regulatory requirements that must be met by companies that use reclaimed water for cooling. The state regulations or guidelines often include restrictions on the quality of the reclaimed water that can be used for cooling. These generally focus on protection of public health and the environment. The primary public health concern is controlling the levels of bacteria and other microbiological organisms that may cause diseases. This objective is accomplished by enacting limitations on fecal or total coliforms, chlorine or other disinfectants, and turbidity. In some cases, state regulations also specify filtration and additional disinfection requirements.

\section{$\underline{\text { Reclaimed Water Quality for Operational Needs }}$}

Users of reclaimed water must also evaluate a second set of criteria concerning the quality of reclaimed water as it relates to their own operational requirements. Some of the chemical constituents of reclaimed water may cause problems (EPRI 2003; Ritz and Spurell 1996). Some examples include:

- Mineral scaling from calcium phosphate and other products.

- Corrosion, pitting, and stress cracking damage to metal heat transfer surfaces and to structural metal surfaces (e.g., damage to copper, copper alloys, and other "yellow metals" from ammonia).

- Biofouling of heat transfer surfaces and excessive biological growth on cooling tower fill material surfaces from BOD, phosphate, and ammonia.

In addition, as water is recirculated in a closed-cycle cooling system, some of the water is evaporated. The water that remains will have elevated levels of all the chemical constituents. A measure of the concentration that can be tolerated by a cooling system is known as the "cycles of concentration," which is how many times the water can be concentrated before it creates an operational problem. Cycles of concentration is calculated separately for each chemical constituent by dividing the maximum limiting concentration for the constituent by its actual concentration in the reclaimed water. Next, all of the chemical-specific cycles-of-concentration values are compared. The lowest value is the most restrictive; it dictates the amount of recirculation that the cooling system must use.

EPRI (2003) provides a good discussion on cooling tower chemistry and cycles of concentration. Table 7 is reproduced from EPRI (2003). It shows the basic water quality parameters and limiting concentrations for cooling tower recirculating water. The limiting concentrations from Table 7 can be used in the cycles-of-concentration calculations.

Power plant operators can control the water quality and the cycles of concentration in several ways. Some of the concentrated recirculating water can be removed from the system as cooling tower blowdown. In order to replace the water that is lost to evaporation, blowdown, and drift, 


\section{Table 7 - Basic Water Quality Parameters and Limiting Concentrations for Cooling Tower Recirculating Water (Note: Some of the footnotes make references to sections and tables from the original EPRI 2003 document.)}

\begin{tabular}{|c|c|c|}
\hline Parameter & Units & Basic Parameters \\
\hline $\mathrm{Ca}$ & $\mathrm{mg} / \mathrm{I}_{\mathrm{CaCO}}$ & $900(\max )_{(5)}$ \\
\hline $\mathrm{Ca} \times \mathrm{SO}_{4}$ & $(\mathrm{mg} / \mathrm{l})^{2}$ & 500,000 \\
\hline Ca with $\mathrm{PO}_{4}$ present & $\mathrm{mg} / \mathrm{l}_{\mathrm{CaCO}}$ & (Refer to Table 2-3b) \\
\hline $\mathrm{Mg} \times \mathrm{SiO}_{2}$ & $\mathrm{mg} / \mathrm{l}_{\mathrm{CaCO}} \times \mathrm{mg} / \mathrm{lsiO}_{\mathrm{SiO}}$ & $35,000_{(2)} \quad 75,000_{(3)}$ \\
\hline $\mathrm{HCO}_{3}+\mathrm{CO}_{3}$ & $\mathrm{mg} / \mathrm{l}_{\mathrm{CaCO}}$ & $30-50_{(2)} \quad 200-250_{(3)}$ \\
\hline $\mathrm{SO}_{4}$ & $\mathrm{mg} / \mathrm{l}$ & (Note 5) \\
\hline $\mathrm{SiO}_{2}$ & $\mathrm{mg} / \mathrm{l}$ & 150 \\
\hline Fe (Total) & $\mathrm{mg} / \mathrm{l}$ & $<0.5$ \\
\hline Mn & $\mathrm{mg} / \mathrm{l}$ & $<0.5$ \\
\hline $\mathrm{Cu}$ & $\mathrm{mg} / \mathrm{l}$ & $<0.1$ \\
\hline Al & $\mathrm{mg} / \mathrm{l}$ & $<1$ \\
\hline S & $\mathrm{mg} / \mathrm{l}$ & 5 \\
\hline $\mathrm{NH}_{3}$ & $\mathrm{mg} / \mathrm{l}$ & $<2(9)$ \\
\hline $\mathrm{pH}$ & & $6.8-7.2(2) \quad 7.8-8.4_{(3)}$ \\
\hline pH with $\mathrm{PO}_{4}$ present & & $7.0-7.5_{(4)}$ \\
\hline TDS & $\mathrm{mg} / \mathrm{l}$ & 70,000 \\
\hline TSS & $\mathrm{mg} / \mathrm{l}$ & $<100_{(6)}-<300_{(7)}$ \\
\hline BOD & $\mathrm{mg} / \mathrm{l}$ & $<100_{(4)}$ \\
\hline COD & $\mathrm{mg} / \mathrm{l}$ & $<100_{(4)}$ \\
\hline Langelier $\mathrm{SI}_{(8)}$ & & $<0$ \\
\hline \multicolumn{2}{|l|}{ Rysnar SI ${ }_{(8)}$} & $>6$ \\
\hline Notes..... & & \\
\hline $\begin{array}{l}\text { 1. Cooling tower } \mathrm{c} \\
\text { concentration. }\end{array}$ & $\begin{array}{l}\text { rculating water concen } \\
\text { Refer to Table } 3-1 \text { and }\end{array}$ & $\begin{array}{l}\text { rations. } \mathrm{PO}{ }_{4} \text { refers to total phosphate } \\
\text { or detailed calculation pocedures. }\end{array}$ \\
\hline Without scale in & hibitor. & \\
\hline Assumes scale & nhibitor is present. & \\
\hline Consult with sp & cialty chemical provide & before finalizing control parameters. \\
\hline Refer to the $\mathrm{Ca}$ & $\mathrm{O}_{4}$ limit. & \\
\hline$<100 \mathrm{mg} / \mathrm{l} \mathrm{TSS}$ & with film fill. & \\
\hline$<300 \mathrm{mg} / \mathrm{TSS}$ & vith open fill. & \\
\hline $\begin{array}{l}\text { Refer to Appen } \\
\text { Indices for calci }\end{array}$ & $\begin{array}{l}\text { ix A for a discussion of } \\
\text { m carbonate. }\end{array}$ & the Langelier and Ryznar Saturation \\
\hline $\begin{array}{l}<2 \mathrm{mg} / \mathrm{l} \mathrm{NH} \\
3 \text { ap } \\
\text { This does not a }\end{array}$ & $\begin{array}{l}\text { lies when copper bear } \\
\text { ply to } 70-30 \text { or } 90-10 \text { c }\end{array}$ & $\begin{array}{l}\text { ng alloys are present in the cooling system. } \\
\text { opper nickel. }\end{array}$ \\
\hline
\end{tabular}

Source: Copyright (C) 2003. Electric Power Research Institute 1005359, Use of Degraded Water Sources as Cooling Water in Power Plants. Used with Permission.

new makeup water is added to the system. Operators can adjust the flow volumes of blowdown and makeup to maintain suitable chemistry in the recirculating water. Another means of controlling water quality and increasing the cycles of concentration is to treat the incoming reclaimed water before it is added to the recirculating system. Many different treatment processes can be used to target those constituents that are likely to limit the cycles of concentration or that could cause harm to components of the cooling system. The next section discusses treatment processes. 


\section{Treatment of Reclaimed Water}

Reclaimed water is treated at the municipal wastewater treatment plant to at least secondary treatment standards in order to comply with federal EPA requirements. In some states (e.g., California), reclaimed water must be treated to tertiary treatment levels. However, other states place no additional requirements beyond secondary treatment on the quality of reclaimed water. In most applications, if the reclaimed water is not already treated beyond secondary standards, the power plant using the water for cooling will either treat it at the power plant site or pay the wastewater treatment utility to provide additional treatment.

Table 8 (reproduced from EPA 2004) shows the starting treatment levels and the additional treatment provided for reclaimed water used for power plant cooling at eight facilities. The starting level of treatment ranges from secondary to tertiary. The additional treatment steps include chemical addition, clarification, disinfection, $\mathrm{pH}$ adjustment, and biological treatment.

Two other examples of applying upgraded treatment before using reclaimed water for power plant cooling were described in the literature during the past year. The first example was published in a special issue of Power Magazine in August 2006 (Power Magazine 2006). The Public Service Enterprise Group (PSEG) decided to update and expand an old plant in Linden, New Jersey, to include two new combined-cycle units. PSEG made arrangements with the nearby Linden/Roselle Sewage Authority (LRSA) to receive 8,100 gallons per minute (gpm) of reclaimed water. The reclaimed water is piped from the LRSA wastewater treatment plant to an auxiliary treatment facility located one mile from the Linden power plant. There, the water is chlorinated and filtered, then sent to the cooling tower system. If the power plant does not use all the water, the remainder is returned to the LRSA wastewater treatment plant, cleaner than when it left there. One unintended impact of using reclaimed water in the Linden station was that corrosion problems developed with the Type 316 stainless steel condenser tubes from chlorides and other components in the reclaimed water. According to Schumerth (2007), the Linden plant and another nearby PSEG plant needed to replace their relatively new stainless steel tubes with titanium tubes.

The second example was described in a Water Environment Federation (WEF) Plant Profile in October 2006 (WEF 2006). The Clear Lake Sanitation District (CLSD) wastewater treatment plant in Clear Lake, Iowa, expanded its capacity from 2.2 MGD to 8.2 MGD in 2002. CLSD has been providing reclaimed water to a nearby Alliant power plant since December 2003. The reclaimed water is piped about 6 miles to the power plant, where $60-80 \%$ of the water is evaporated in cooling towers. Blowdown from the towers is piped back to the CLSD wastewater treatment plant, dechlorinated, and then discharged to Beaver Dam Creek. As part of the agreement, CLSD added tertiary filtration and disinfection steps. Alliant paid for this supplemental upgrade, which included a 150,000-gallon, post-secondary equalization basin, a new tertiary treatment building that houses three six-disk cloth media filters, and an ultraviolet disinfection system. The plant uses a sequencing batch reactor system for secondary treatment. Treated effluent flows by gravity to the equalization basin and is then pumped into one of the three cloth media filters. Finally, the flow passes through an ultraviolet disinfection system prior to being sent to a storage tank at the Alliant Energy power plant site. Liquid chlorination was 
installed to provide a residual that would protect against any biological growth in the pipe during periods when the power plant is shut down.

Table 8 - Treatment Processes for Power Plant Cooling Water ${ }^{a}$

\begin{tabular}{|c|c|c|c|}
\hline $\begin{array}{l}\text { Power Facility and } \\
\text { Location }\end{array}$ & $\begin{array}{l}\text { Average Cooling } \\
\text { Water Supply and } \\
\text { Return Flow }\end{array}$ & $\begin{array}{l}\text { Treatment Processes at } \\
\text { Wastewater Treatment Plant }\end{array}$ & $\begin{array}{l}\text { Treatment of Cooling Water at } \\
\text { Power Plant }\end{array}$ \\
\hline $\begin{array}{l}\text { Lancaster County } \\
\text { Resource Recovery } \\
\text { Center, Marietta, PA }\end{array}$ & $\begin{array}{l}\text { Supply }=0.65 \text { MGD } \\
\text { Return = } 0 \\
\text { Zero discharge: all } \\
\text { blowdown is } \\
\text { evaporated or leaves } \\
\text { plant as sludge. }\end{array}$ & $\begin{array}{l}\text { Secondary treatment with alum, } \\
\text { flocculation, and polymer addition } \\
\text { followed by settling and } \\
\text { phosphorus removal }\end{array}$ & $\begin{array}{l}\text { Clarification and addition of ferric } \\
\text { sulfate, polymer, and sodium } \\
\text { hypochlorite }\end{array}$ \\
\hline PSE\&G, Ridgefield, NJ & $\begin{array}{l}\text { Supply }=0.3 \text { to } 0.6 \\
\text { MGD. } \\
\text { The blowdown is } \\
\text { disposed of with plant } \\
\text { wastewater to local } \\
\text { sewer system. }\end{array}$ & Secondary treatment & $\begin{array}{l}\text { Water chemistry is controlled with } \\
\text { biocide, neutralization, and surfactant }\end{array}$ \\
\hline $\begin{array}{l}\text { Hillsborough County } \\
\text { Solid Waste to Energy } \\
\text { Recovery Facility } \\
\text { (operated by Ogden } \\
\text { Martin Corp.), Tampa, FL }\end{array}$ & $\begin{array}{l}\text { Supply = 0.7 MGD } \\
\text { (includes some use for } \\
\text { irrigation water). } \\
\text { The blowdown of } \\
0.093 \text { MGD is mixed } \\
\text { with plant wastewater } \\
\text { and returned to the } \\
\text { WWTP. }\end{array}$ & $\begin{array}{l}\text { Advanced treatment with high-level } \\
\text { disinfection. Partial tertiary } \\
\text { treatment removes phosphorus. }\end{array}$ & $\begin{array}{l}\text { Addition of chlorine, biocide, } \\
\text { surfactant, trisodium phosphate, and } \\
\text { sulfuric acid }\end{array}$ \\
\hline $\begin{array}{l}\text { Nevada Power - Clark } \\
\text { and Sunrise Stations, } \\
\text { Las Vegas, NV }\end{array}$ & $\begin{array}{l}\text { Supply = } 2.72 \text { MGD } \\
\text { average to Clark } \\
\text { Station } \\
\text { Return = } 0 \\
\text { Blowdown is } \\
\text { discharged to holding } \\
\text { ponds for evaporation. }\end{array}$ & $\begin{array}{l}\text { Advanced secondary treatment } \\
\text { with nitrification, denitrification, and } \\
\text { biological phosphorus removal; } \\
\text { tertiary treatment using dual-media } \\
\text { filtration and disinfection with } \\
\text { chlorine }\end{array}$ & $\begin{array}{l}\text { None at present time; previously had } \\
\text { been treated with lime and softener }\end{array}$ \\
\hline $\begin{array}{l}\text { Panda Brandywine, } \\
\text { Brandywine, MD }\end{array}$ & $\begin{array}{l}\text { Supply }=0.65 \text { MGD } \\
\text { Blowdown is returned } \\
\text { to the WWTP. }\end{array}$ & $\begin{array}{l}\text { Secondary treatment, biological } \\
\text { nutrient removal, sand filters }\end{array}$ & $\begin{array}{l}\text { Addition of corrosion inhibitors, } \\
\text { sodium hypochlorite, acid, and anti- } \\
\text { foaming agents }\end{array}$ \\
\hline $\begin{array}{l}\text { Chevron Refineries, } \\
\text { El Segundo and } \\
\text { Richmond, CA }\end{array}$ & $\begin{array}{l}\text { Supply }=3 \text { to } 5 \text { MGD } \\
\text { Return }=0\end{array}$ & $\begin{array}{l}\text { Tertiary treatment at both. } \\
\text { El Segundo uses an ammonia } \\
\text { stripping process; Richmond uses } \\
\text { a caustic soda treatment process. }\end{array}$ & $\begin{array}{l}\text { Richmond plant uses a commercial } \\
\text { chemical additive [chemistry not } \\
\text { specified in EPA (2004)] }\end{array}$ \\
\hline $\begin{array}{l}\text { Curtis Stanton Energy } \\
\text { Center, Orange County, } \\
\text { FL }\end{array}$ & $\begin{array}{l}\text { Supply = } 10 \text { MGD } \\
\text { Return = } 0 \\
\text { Blowdown is } \\
\text { evaporated in } \\
\text { concentrator and } \\
\text { crystallizer units at the } \\
\text { power plant. }\end{array}$ & $\begin{array}{l}\text { Advanced wastewater treatment } \\
\text { including filtration, disinfection, and } \\
\text { biological nutrient removal }\end{array}$ & $\begin{array}{l}\text { Addition of acid, scale inhibitor, } \\
\text { chlorine; control of calcium }\end{array}$ \\
\hline $\begin{array}{l}\text { Palo Verde Nuclear } \\
\text { Plant, Phoenix, AZ }\end{array}$ & $\begin{array}{l}\text { Total supply to three } \\
\text { units }=72 \text { MGD } \\
\text { Return }=0 \\
\text { All blowdown is } \\
\text { evaporated in ponds. }\end{array}$ & Secondary treatment & $\begin{array}{l}\text { Tertiary treatment plant consisting of } \\
\text { trickling filters for ammonia removal, } \\
\text { clarification for removal of } \\
\text { phosphorus, magnesium, and silica; } \\
\text { addition of dispersants, defoaming } \\
\text { agents, and sodium }\end{array}$ \\
\hline
\end{tabular}

${ }^{\mathrm{a}}$ The information included in this table is reproduced or paraphrased from an earlier study. The information may not match the more current data shown in the database in Appendix A.

Source: EPA (2004), which in turn credits the information to DeStefano (2000).

An interesting anecdote relating to the Alliant plant (Carney 2007) involves the cycles of concentration in the cooling tower. Reportedly, Alliant designed the cooling tower to operate at 7 to 9 cycles of concentration. The plant must operate at 2 cycles of concentration in order for 
the cooling tower blowdown to be clean enough to send back to the CLSD wastewater treatment plant. High sulfates and total dissolved solids are causing the problem.

Another example of incremental treatment requirements can be found in two Wastewater Treatment and Emergency Water Cooperative Agreements made between the City of Deming, New Mexico, and a power plant operator that intended to use reclaimed water from the City's wastewater treatment plant. The original agreement was signed in December 2003. Section 3.1 rather vaguely outlined the obligations of the power plant (the User):

"In order to meet User's needs with respect to the delivery of Final Treated Effluent, User shall, unless this agreement is otherwise terminated, at its sole cost and expense, modify and upgrade the Existing Facility [the city's wastewater treatment in its configuration at the time the agreement was signed] ...."

In May 2006, following a change in the corporate owners and operators of the power plant, the Agreement was amended. Among the other changes, Section 3.1 was expanded to say:

"In order to meet User's needs with respect to the delivery of Final Treated Effluent, User shall, unless this Agreement is otherwise terminated, at its sole cost and expense, modify and upgrade the Existing Facility prior to User taking any water from the Wastewater Treatment Plant. Such modifications and upgrades will consist of, among other things: a new 35 million gallon capacity covered effluent storage pond, wet wells, sand filters, and in-line water quality monitoring instruments that will provide the necessary water quality...." [new text is underlined]

Now, the required upgrades to the treatment system are clearly identified. 


\section{Chapter 5 - The Panda Brandywine Plant}

\section{Plant Location and Description}

Panda Global Services operates the Panda Brandywine power plant in Brandywine, Prince George's County, Maryland. The site is located just east of Route 301, about 15 miles southeast of the Washington, DC beltway. Figure 2 shows the plant location in relation to Washington, DC. Figure 2 also shows the location of the Mattawoman Wastewater Treatment Plant, which provides reclaimed water to Panda Brandywine.

\section{Figure 2 - Regional Map Showing Location of Plants}

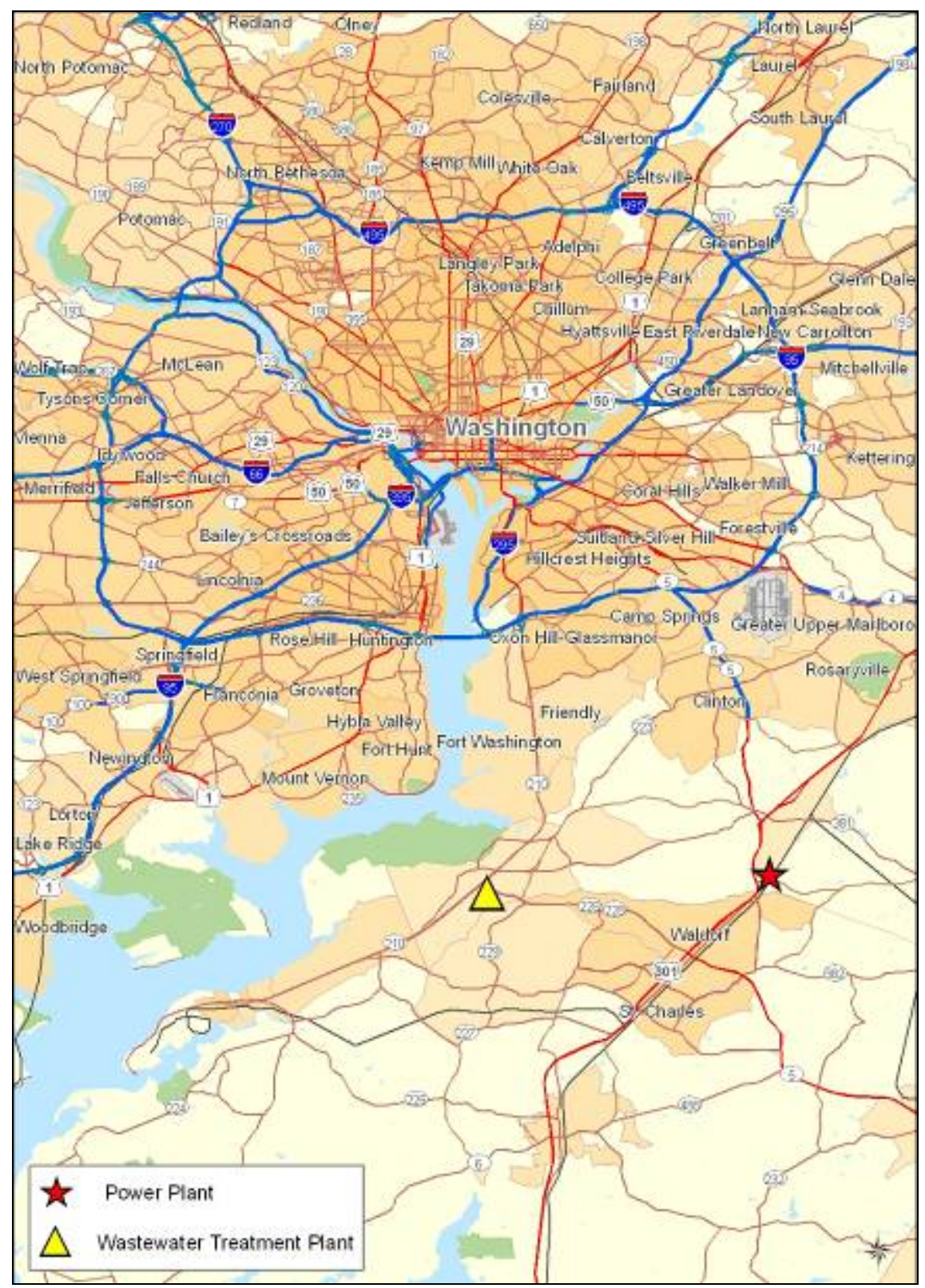


Figure 3 shows an aerial photograph of the plant site. The site is bounded by a road on the west and railroad tracks on the east. The four mechanical draft cooling towers can be seen in the lower left corner of Figure 3.

Figure 3 - Aerial Photo Showing Panda Brandywine Site

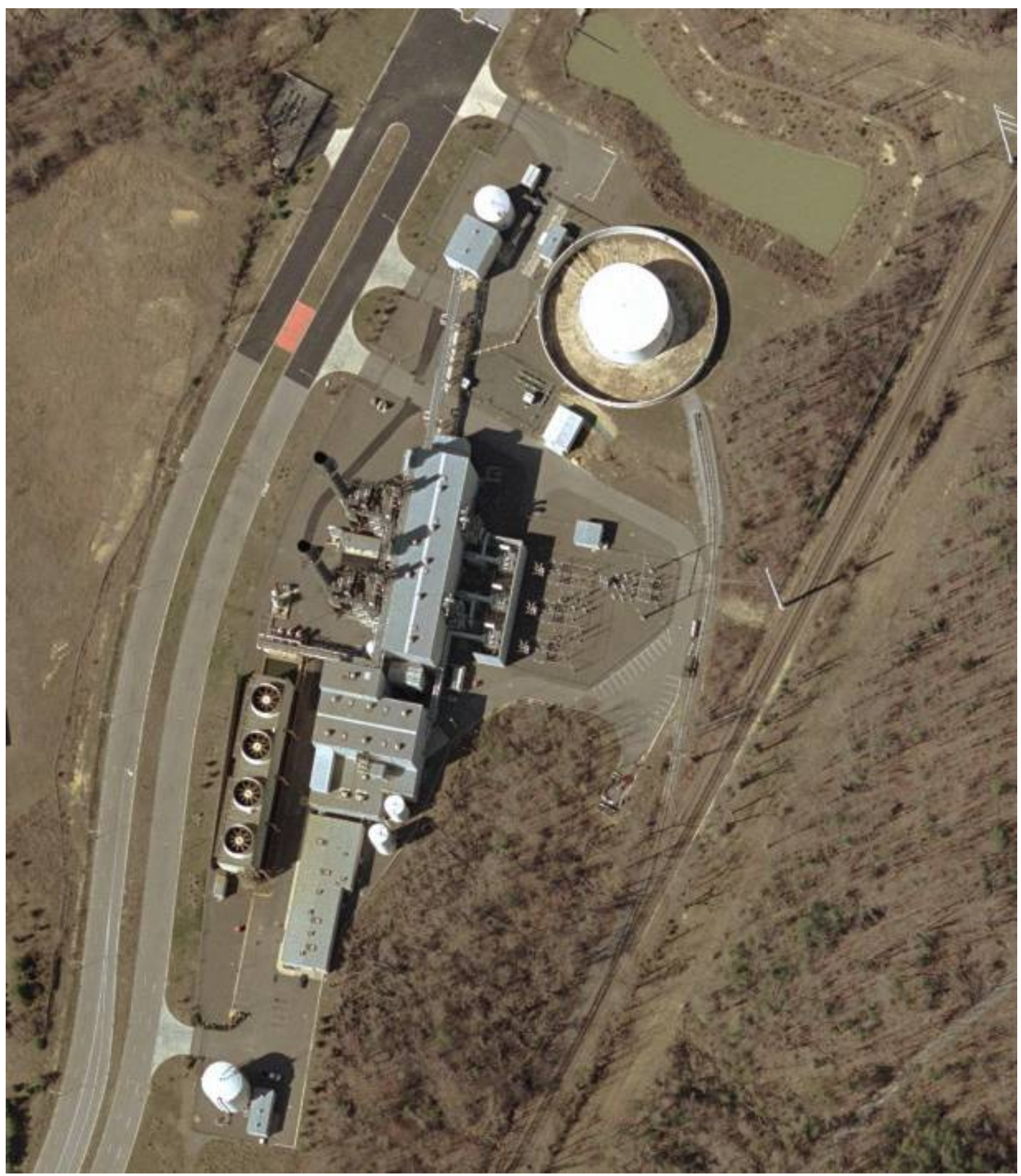


The plant began production in October 1996. The plant is a natural gas-fired combined-cycle plant with two combustion turbines and two heat recovery steam generators. It has a capacity of 230 MW. Number 2 distillate oil (stored in the large round tank seen in the upper right corner of Figure 3) is used as a back-up fuel for a limited number of hours each year.

The plant uses about 1.5 MGD of tertiary-treated water from the Washington Suburban Sanitary Commission (WSSC) Mattawoman Wastewater Treatment Plant, located about 17 miles to the west in Charles County, Maryland. The water travels through a 17-mile pipeline to the Panda site. Reclaimed water has been used at the Panda plant since 1997. Until recently, Mattawoman chlorinated the wastewater for disinfection, then dechlorinated prior to discharge through its NPDES outfall. The water sent to Panda was withdrawn prior to dechlorination, so that a chlorine residual could be maintained in the pipeline.

Recently, Mattawoman switched to ultraviolet as its main source of disinfection. The plant still provides chlorination for the side stream of water that enters the reclaimed water pipeline. When the reclaimed water reaches Panda Brandywine, it is chlorinated again using liquid sodium hypochlorite. Panda Brandywine also adds other chemicals (e.g., corrosion inhibitors) for process control. These chemicals would be added regardless of the source of cooling water. Cooling tower blowdown, sewage, and other industrial wastewater are piped back to Mattawoman for treatment.

The Mattawoman WWTP recently upgraded its treatment to provide biological nutrient reduction (BNR), a process that removes the total nitrogen and phosphorus in municipal wastewater to low levels. According to a fact sheet published by the Maryland Department of the Environment (MDE), the Mattawoman WWTP's goal is to reduce total nitrogen to an average level of $3 \mathrm{mg} / \mathrm{L}$ and the total phosphorus to an average level of $0.18 \mathrm{mg} / \mathrm{L}$ prior to discharging the water into the receiving waters (MDE 2007). Prior to the upgrades, Panda Brandywine ran the cooling towers at 4-5 cycles of concentration. Now, following the Mattawoman WWTP upgrades, Panda Brandywine can run at 8 to10 cycles of concentration.

\section{$\underline{\text { Site Visit }}$}

The author visited the Panda Brandywine site on April 17, 2007. Mark Briggs, the plant manager, provided a tour. Several photographs from the visit are shown in the following figures. The most obvious feature is the bright purple paint used on all pumps, valves, and pipes conveying reclaimed water. Figure 4 shows the fire hydrant located at the point at which the reclaimed water pipeline enters the Panda Brandywine property. Figures 5-7 show different views of the purple piping and pumps used to move reclaimed water into and out of the cooling towers.

The weather that day was quite windy. Figure 8 shows the large plume exiting the top of the cooling tower. Figure 9 shows the mist and spray that blew off of the sides of the cooling towers. 
Figure 4 - Fire Hydrant Conveying Reclaimed Water (Source: Veil 2007)

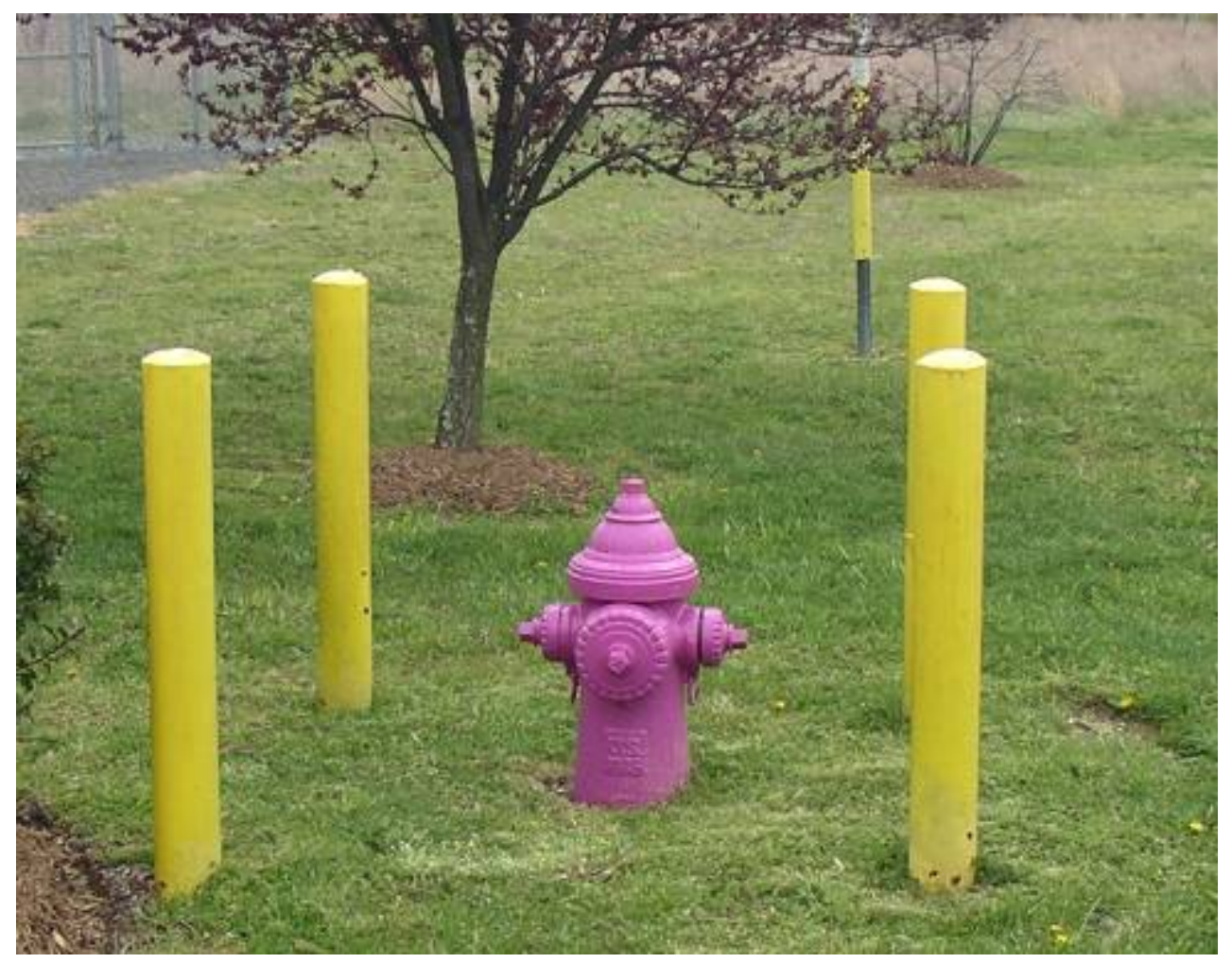

Figure 5 - Reclaimed Water Line Entering Cooling Tower (Source: Veil 2007)

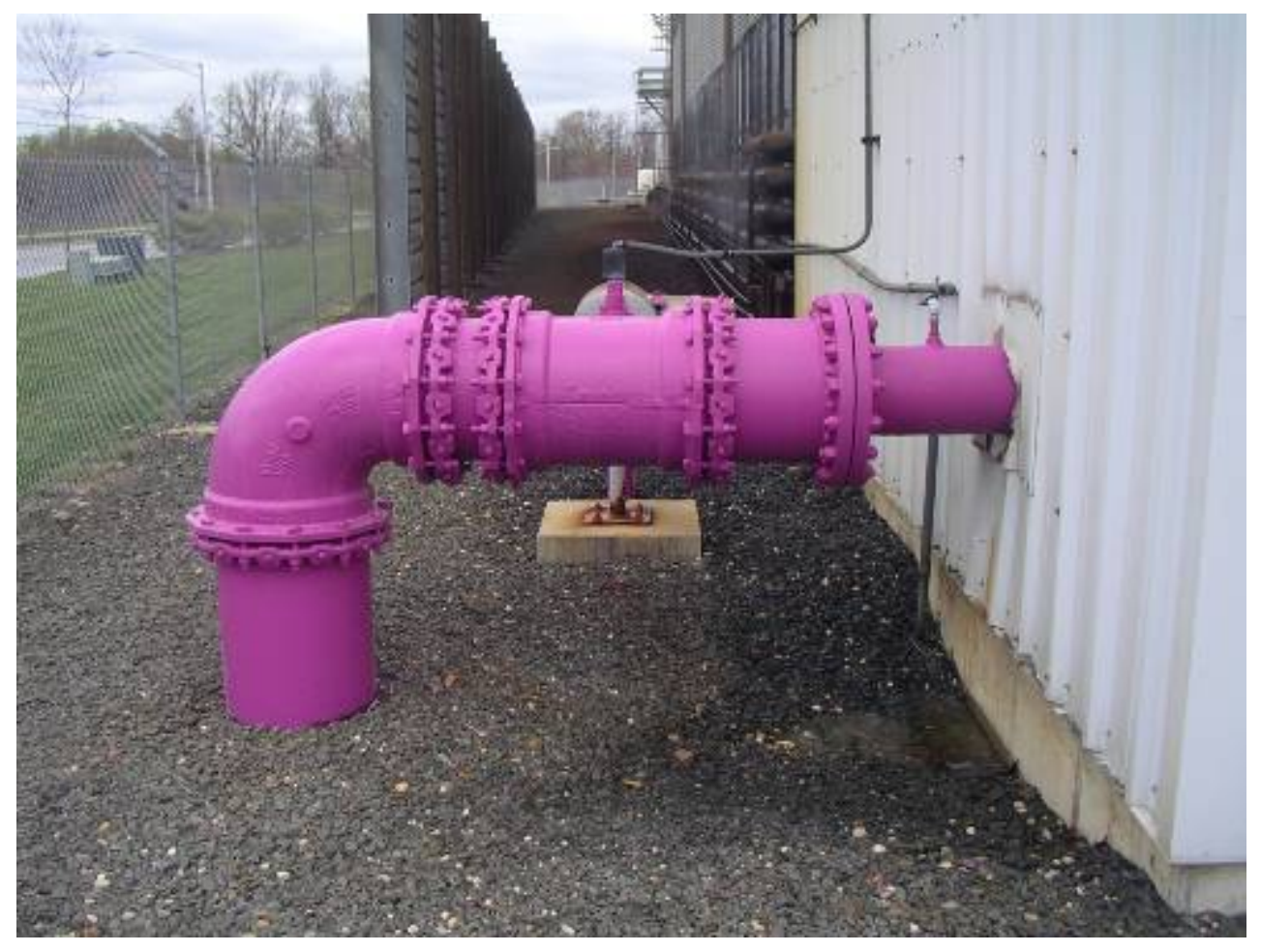


Figure 6 - Reclaimed Water Lines and Cooling Tower (Source: Veil 2007)

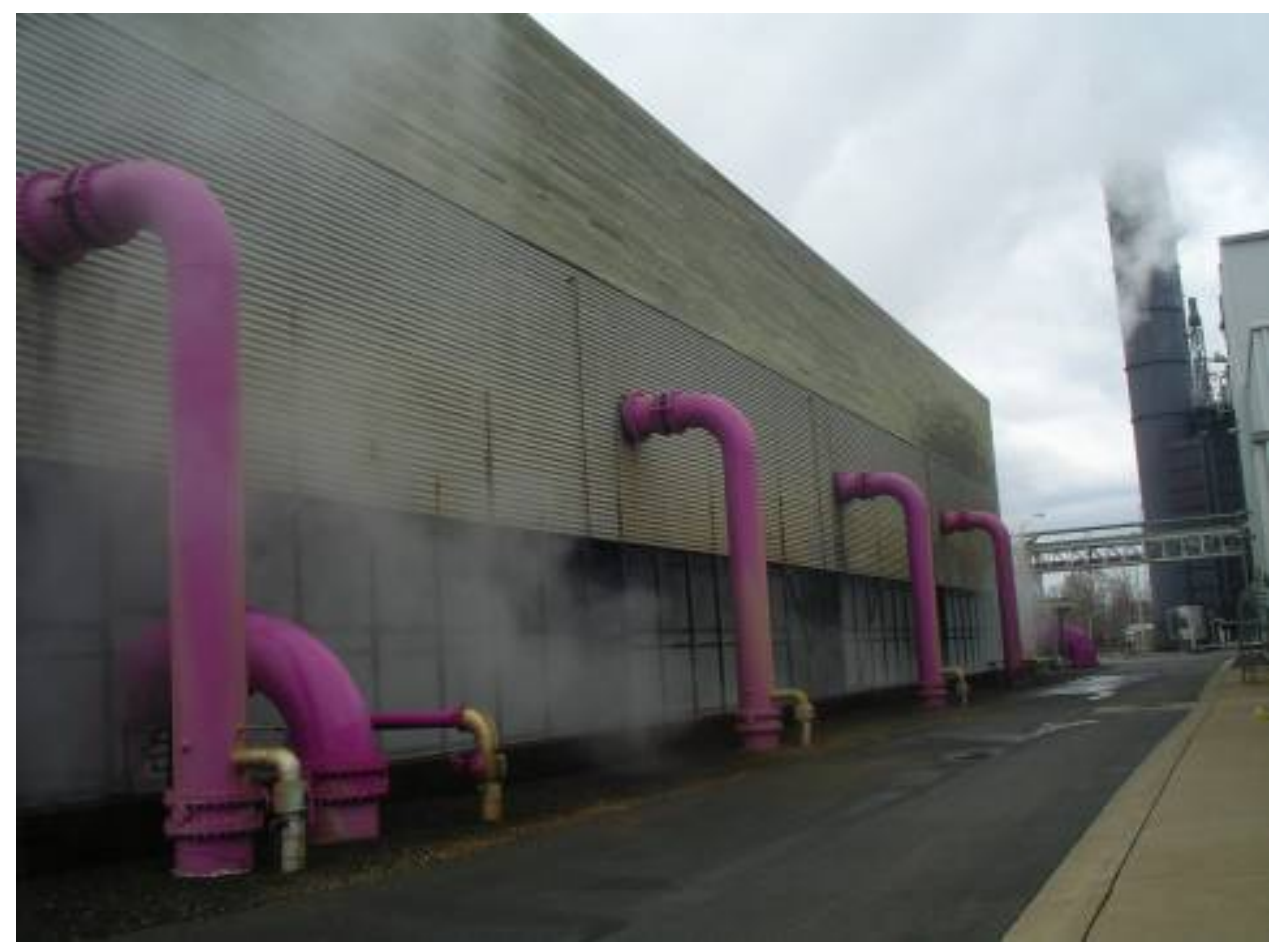

Figure 7 - Reclaimed Water Pipe and Recirculating Pumps (Source: Veil 2007)

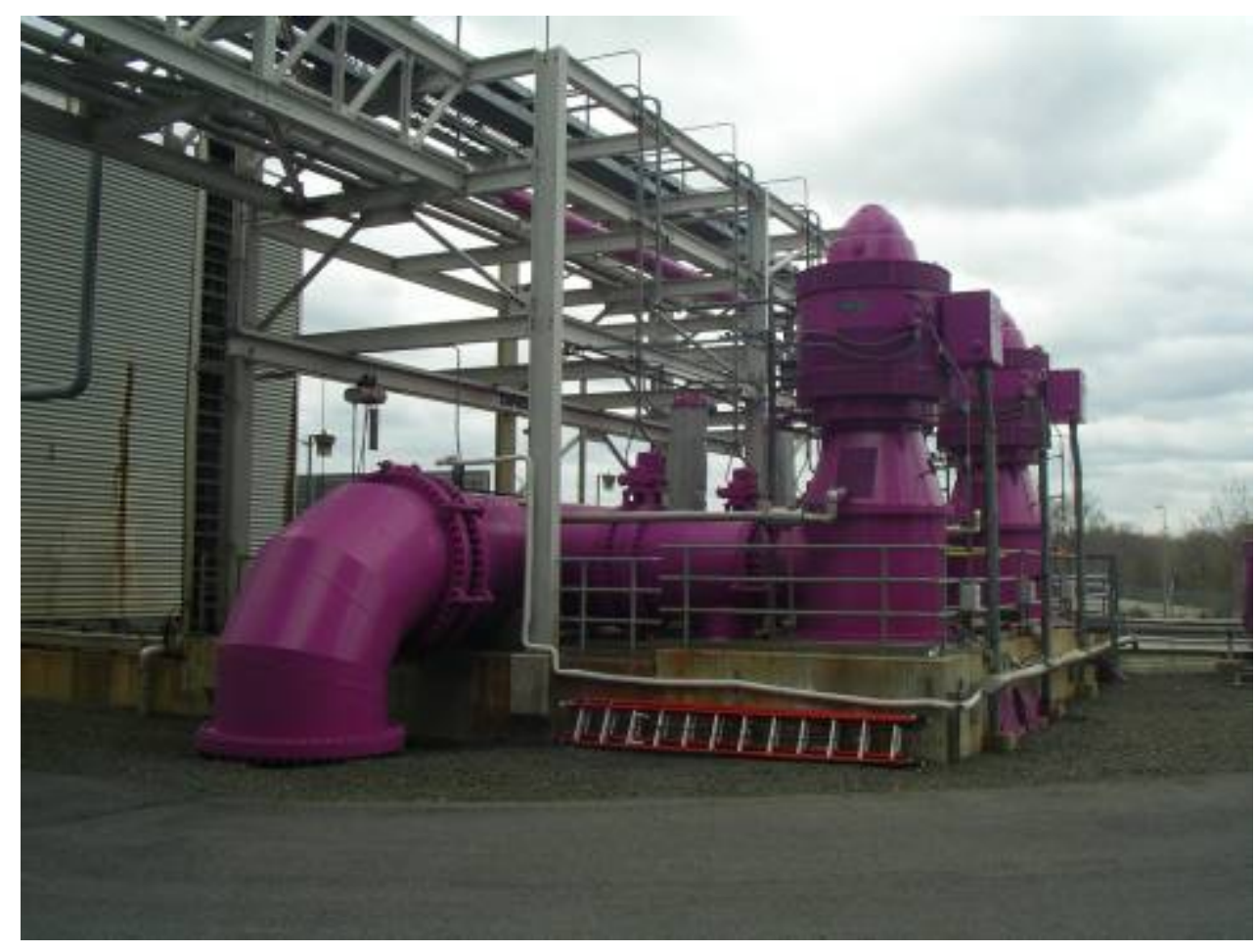


Figure 8 - Cooling Tower Plume (Source: Veil 2007)

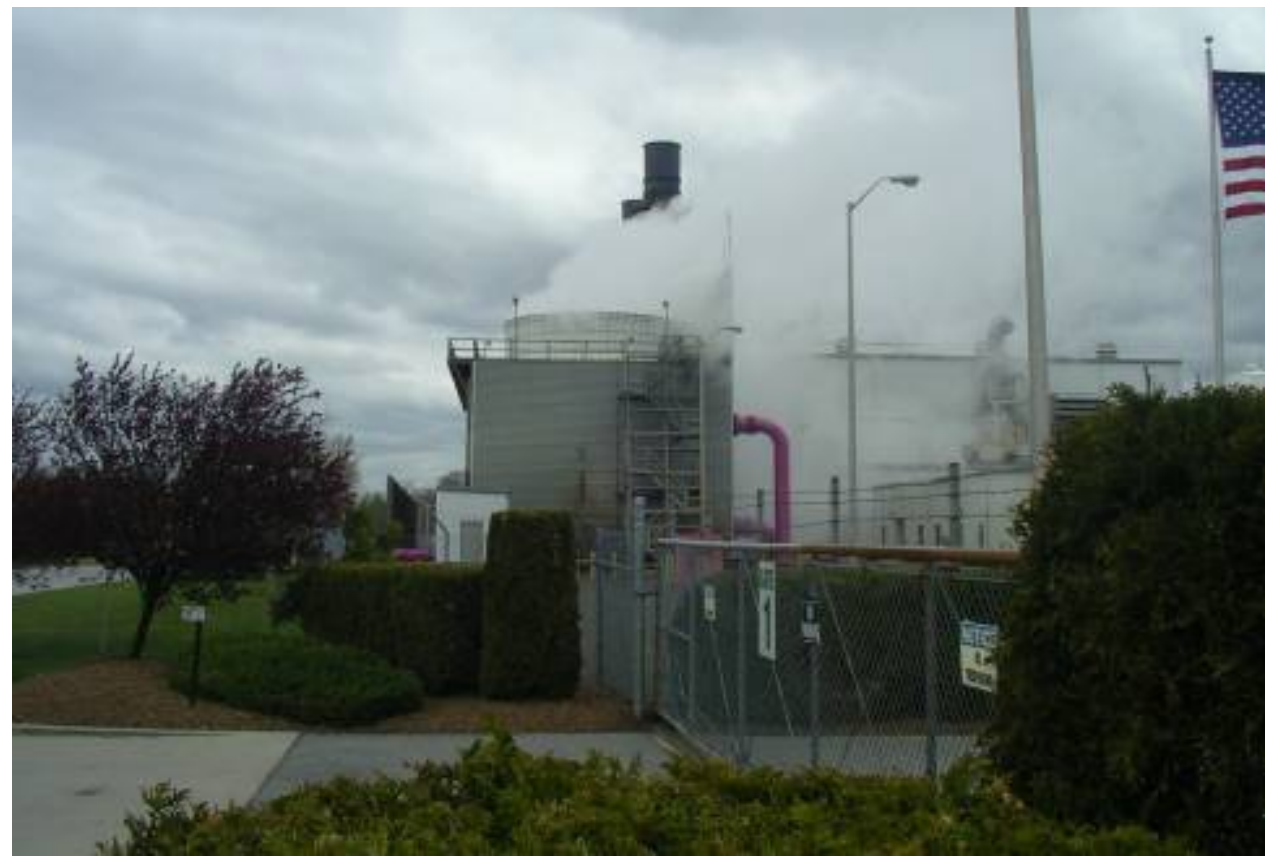

Figure 9 - Reclaimed Water Falling through Cooling Tower and Forming a Mist (Source: Veil 2007)

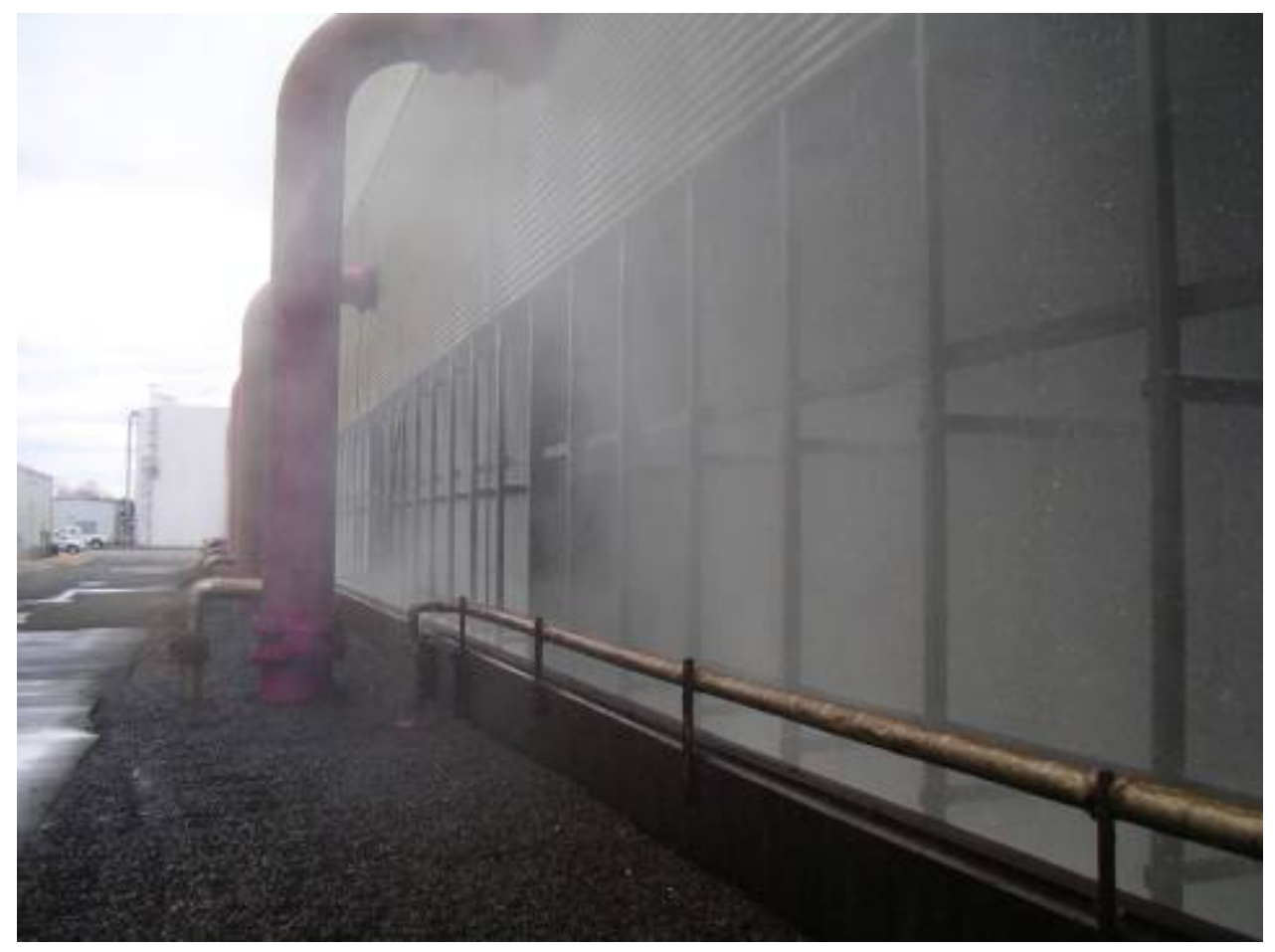




\section{Chapter 6 - Findings and Conclusions}

Reclaimed water represents a valuable water resource with many potential applications. As the power industry sites new plants or expands capacity at existing sites, it must identify sufficient supplies of water to cool the steam. Reclaimed water can help meet that need. About 50 power plants are currently using reclaimed water for cooling. Several of these are also using reclaimed water for air pollution control equipment like scrubbers. As more plants add scrubbers, the need for additional water will rise, too.

This report includes a unique database that identifies and describes power facilities in the United States that are using reclaimed water. Most of the examples are located in Florida, California, and Texas, all of which have dealt with freshwater shortages for many years. Reclaimed water is being used throughout the country, however. Thirteen other states have facilities that are currently using reclaimed water. A few of the power plants have been using reclaimed water since the 1960s, although most began the practice since 1990 .

Nearly all regulatory requirements relating to the use of reclaimed water are found at the state level. The report reviews the reclaimed water reuse regulations from Arizona, California, Florida, and Texas. New Jersey does not have reclaimed water regulations but has published a technical guidance manual.

Reclaimed water must meet at least secondary treatment standards. Often the state agency that authorizes reclaimed water use for cooling will require tertiary treatment or some form of filtration and disinfection. In addition to treating the reclaimed water for public health and environmental reasons, operators often treat for process reasons. Reclaimed water typically contains chemical parameters that may create problems of scaling, corrosion, biofouling, or stress cracking of some metal surfaces. The report provides examples of power plants that are using reclaimed water and the types of treatments they are employing for process control.

Although reuse of reclaimed water is not a new practice, it is likely to become increasingly popular throughout most of the country. This report and its database can serve as resources for companies looking to use reclaimed water in the future. 


\section{References}

Adcock, C., 2007, personal communication between C. Adcock, Bartow Water Reclamation Facility, Bartow, FL, and J. Veil, Argonne National Laboratory, March 21.

Aliseo, R., 2007, personal communication between R. Aliseo, Broward County North Regional Plant, Pompano Beach, FL, and J. Veil, Argonne National Laboratory, March 21.

Arizona Administrative Code, 2007. Available at:

http://www.azsos.gov/public_services/Title_18/18-11.htm.

Babayan, L., 2007, personal communication between L. Babayan, Burbank Water and Power, Burbank, CA, and J. Veil, Argonne National Laboratory, April 4.

Barksdale, S., 2007, personal communication between S. Barksdale, Columbus Light and Water, Columbus, MS, and J. Veil, Argonne National Laboratory, April 9.

Bergen County Utilities Authority, 2006, "Wastewater Effluent Beneficial Reuse Program.” Available at: http://www.bcua.org/WPC_VT_WasteWaterReUse.htm.

Black, D., 2007, personal communication between D. Black, Environmental Services, Largo, FL, and J. Veil, Argonne National Laboratory, March 27.

Burton, T., 2007, personal communication between T. Burton, Kissimmee Department of Water Resources, Kissimmee, FL, and J. Veil, Argonne National Laboratory, March 22.

California Energy Commission, undated, "Power Plant Database.” Available at: http://www.energy.ca.gov/database/POWER_PLANTS.XLS.

Carlson, J., 2007, personal communication between J. Carlson, Sunflower Electric, and J. Veil, Argonne National Laboratory, February 5.

Carney, B., 2007, electronic mail from B. Carney, DOE National Energy Technology Laboratory, Morgantown, WV, to J. Veil, Argonne National Laboratory, March 20. The email transmitted notes made by NETL's Andrea McNemar concerning a March 20 conference call.

Castro, A., 2007, electronic mail from A. Castro, Orange County Utilities, Water Reclamation Division, Orlando, FL, to J. Veil, Argonne National Laboratory, March 22.

City of Denton, Texas, 2003, "Solid Waste - Wastewater - Water," white paper, October 1. Available at: http://www.cityofdenton.com/pages/ mygovewhitepaperssolidwwaterwater.cfm?object=3481\&folderID=258\&action=files.

Cogentrix Energy, Inc., undated, “Caledonia Water Supply Line.” Available at: http://www.willbros.com/_filelib/FileCabinet/Projects/North_America/Caledonia\%20Water.pdf? FileName $=0108$.pdf. 
CSWRCB (California State Water Resources Control Board), 2000, "Municipal Wastewater Reclamation Survey," prepared by the California State Water Resources Control Board, Office of Water Recycling, May 24.

Curiel, M., 2007, personal communication between M. Curiel, Ft. Myers Central Wastewater Treatment Plant, Ft. Myers, FL, and J. Veil, Argonne National Laboratory, March 20.

Delta Diablo Sanitation District, 2001, “Recycled Water Facility Dedication,” June 1. Available at: http://www.ddsd.org/pdfs/RWF_Brochure.pdf.

DeStefano, E. C., 2000, "Panda Perkiomen Power Plant Supply Water Quality Comparisons,” memorandum dated September 13, 2000 (referenced in EPA 2004 as the source of information for a table).

DOE (U.S. Department of Energy), 2006, "Energy Demands on Water Resources, Report to Congress on the Interdependency of Energy and Water," U.S. Department of Energy, December, 80 pp.

Duncan, J., 2007, personal communication between J. Duncan, Hillsborough County Water Resource Services, Tampa, FL, and J. Veil, Argonne National Laboratory, March 23.

EEI (Edison Electric Institute), 1996, “Environmental Directory of U.S. Powerplants,” Edison Electric Institute, Washington, D.C.

EIA (Energy Information Administration), 2005, "EIA 767 Data Files - Annual Steam-Electric Plant Operation and Design Data,” U.S. Department of Energy, Energy Information

Administration. Data available at: http://www.eia.doe.gov/cneaf/electricity/page/eia767.html.

El Paso Water Utilities, 2007, "Wastewater Treatment: Northeast - Fred Hervey Plant.” Available at: http://www.epwu.org/wastewater/fred_hervey_reclaimation.html\#.

EPA (U.S. Environmental Protection Agency), 2004, “Guidelines for Water Reuse,” EPA/625/R04/108, U.S. Environmental Protection Agency and U.S. Agency for International Development, September. Available at: http://www.epa.gov/nrmrl/pubs/625r04108/625r04108.pdf.

EPRI (Electric Power Research Institute), 2003, "Use of Degraded Water Sources as Cooling Water in Power Plants," prepared for the California Energy Commission by the Electric Power Research Institute, EPRI Report No. 1005359, October. Available at: http://www.energy.ca.gov/reports/2004-02-23_500-03-110.PDF.

fc.gov, 2007, “Water Reclamation Facilities,” City of Fort Collins (Colorado). Available at: http://fcgov.com/wastewater/facilities.php. 
Feeley, T.J., III, 2005, "Enhancing the Environmental Performance of Coal-Fired Power Plants DOE’s Innovations for Existing Plants Program,” February. Available at: http://www.netl.doe.gov/technologies/coalpower/ewr/index.html.

Florida Department of Environmental Protection, 2007a, "Industrial Uses of Reclaimed Water.” Available at: http://www.dep.state.fl.us/water/reuse/industry.htm.

Florida Department of Environmental Protection, 2007b, "Water Resource Management Rules in Numerical Order.” Available at: http://www.dep.state.fl.us/water/rulesnum.htm\#62-600.

GRDA (Geothermal Resources Development Account) and California Energy Commission, undated, "Santa Rosa Reclaimed Water Geysers Recharge Project." Available at: http://www.energy.ca.gov/geothermal/fact_sheets/geothermal_projects/SANTA_ROSE_RECLA IMED_H20.PDF.

Grenier, S., 2007, personal communication between S. Grenier, Southbridge Department of Public Works, Southbridge, MA, and J. Veil, Argonne National Laboratory, April 4.

Guerts, G., 2007, personal communication between G. Guerts, Heart of the Valley Metropolitan Sewerage District, Kaukauna, WI, and J. Veil, Argonne National Laboratory, April 18.

Harrell, S., 2007, personal communication between S. Harrell, Vero Beach Wastewater Treatment Plant, Vero Beach, FL, and J. Veil, Argonne National Laboratory, March 20.

Hester, T., 2007, personal communication between T. Hester, Utilities Department, Ennis, TX, and J. Veil, Argonne National Laboratory, April 17.

Hutson, S.S., N.L. Barber, J.F. Kenny, K.S. Linsey, D.S. Lumia, and M.A. Maupin, 2004, "Estimated Use of Water in the United States in 2000," U.S. Geological Survey Circular 1268, 46 pp.

JEA, undated, “How JEA Uses Reclaimed Water to Promote Water Conservation.” Available at: http://www.jea.com/community/reclaim.asp.

Johnson, J., 2007, personal communication between J. Johnson, Heart of the Valley Metropolitan Sewerage District, Kaukauna, WI, and J. Veil, Argonne National Laboratory, April 18.

King, G., 2007, personal communication between G. King, City of Tallahassee - Purdom Generating Station, St. Marks, FL, and J. Veil, Argonne National Laboratory, March 22.

Lake County California, undated, "Effluent Pipeline.” Available at: http://www.co.lake.ca.us/Government/DepartmentDirectory/Special_Districts/Wastewater_Syste ms/Effluent_Pipeline.htm.

Lavery, M., 2007, personal communication between M. Lavery, PNM, and J. Veil, Argonne National Laboratory, February 12. 
LCSWMA (Lancaster County Solid Waste Management Authority), undated, "Resource Recovery Facility.” Available at: http://www.lcswma.org/resourceRecovery.asp.

Longoria et al., 2000, "Rate Setting for Industrial Reuse in San Marco, Texas," WateReuse Conference Proceedings, San Antonio, TX, January 30-February 2.

MDE (Maryland Department of the Environment), 2007, "Facts about Mattawoman Wastewater Treatment Plant.” Available at: http://textonly.mde.state.md.us/assets/document/enr/Mattawoman.pdf, visited on July 23, 2007.

Marrinan, P., 2007, personal communication between P. Marrinan, Wheelabrator, North Andover, MA, and J. Veil, Argonne National Laboratory, April 16.

Mauricio, A., 2007, electronic mail from A. Mauricio, El Paso Electric Company, El Paso, TX, and J. Veil, Argonne National Laboratory, April 16.

Metropolitan Area Planning Council, 2005, "Once Is Not Enough - A Guide to Water Reuse in Massachusetts,” November, 32 pp. Available at: http://www.mapc.org/regional_planning/MAPC_Water_Reuse_Report_2005.pdf.

Miller, S., 2007, personal communication between S. Miller, Las Vegas Water Pollution Control Facility, Las Vegas, NV, and J. Veil, Argonne National Laboratory, April 18.

Morgan, D., 2007, electronic mail from D. Morgan, Clark County Water Reclamation District, Las Vegas, NV, to J. Veil, Argonne National Laboratory, April 26.

Morris, M., 2007, personal communication between M. Morris, Jerry Sellers Water Reclamation Facility, Cocoa, FL, and J. Veil, Argonne National Laboratory, March 20.

MPPRP (Maryland Power Plant Research Program), 1997, "Environmental Review of the Panda-Brandywine Cogeneration Project,” PPSE-PB-1, Maryland Power Plant Research Program, February. Available at: http://esm.versar.com/pprp/bibliography/feb02bib/ppse-pb1.pdf.

Mullins, M., 2007, personal communication between M. Mullins, Arizona Department of Environmental Quality, Phoenix, AZ, and J. Veil, Argonne National Laboratory, May 23.

NH Society of Professional Engineers, 2002, “The Observer,” published by the New Hampshire Society of Professional Engineers, January. Available at: http://www.nhspe.org/pages/observer/Jan02.pdf.

NJDEP (New Jersey Department of Environmental Protection), 2005, “Technical Manual Reclaimed Water for Beneficial Reuse,” New Jersey Department of Environmental Protection, Division of Water Quality, January. Available at: http://www.state.nj.us/dep/dwq/techmans/reuseman.pdf. 
Palo Verde Energy Information Center, undated, “Water Reclamation Facility,” brochure describing the water reclamation at Palo Verde Nuclear Generating Facility.

Platte River Power Authority, 2007, "Rawhide Energy Station History.” Available at: http://prpa.org/energysources/rawhidehistory.htm.

Power Magazine, 2006, "Power Magazine’s Top Plants of 2006 - Linden Generating Station, Linden, New Jersey,” August. Available at:

http://www.powermag.com/ExportedSite/Archives/Archives.htm.

Ritz, D.B., and C. Spurell, 1996, "Reclaimed Water for Cooling Tower Make-up: Concerns, Monitoring, and Proven Treatment," paper 96579, presented at Corrosion 96, the NACE International Annual Conference and Exposition, March 26-31, Houston, TX.

Salt River Project/City of Tempe, 2005, "Reclaimed Water Reuse and Water Exchange Program,” December 5. Available at: http://www.azwater.gov/dwr/Content/Hot_Topics/files/SRP_K7-Tempe_KRF.pdf.

Schumerth, D.J., 2007, "Reclaimed Cooling Water's Impact on Surface Condensers and Heat Exchangers,” Power Magazine, March, pp. 28-34.

Tedder, R., 2007, personal communication between R. Tedder, Arizona Public Service, Phoenix, AZ, and J. Veil, Argonne National Laboratory, April 4.

Texas Administrative Code, undated. Available at: http://info.sos.state.tx.us/pls/pub/readtac\$ext.ViewTAC?tac_view=4\&ti=30\&pt=1\&ch=210.

UF Office of Sustainability, 2006, “Cogeneration Plant.” Available at: http://www.sustainable.ufl.edu/operationdetails.asp?op=9.

Varghes, J., 2007, personal communication between J. Varghes, City of Tampa Wastewater Department, Tampa, FL, and J. Veil, Argonne National Laboratory, February 13.

Veil, J., J. Kupar, and M. Puder, 2003, "Use of Mine Pool Water for Power Plant Cooling,” prepared by Argonne National Laboratory for the U.S. Department of Energy, National Energy Technology Laboratory, September, 62 pp. Available at: http://www.ead.anl.gov/pub/dsp_detail.cfm?PubID=2032.

Veil, J.A., and M.G. Puder, 2006, "Potential Ground Water and Surface Water Impacts from Oil Shale and Tar Sands Energy-Production Operations,” ANL/EVS/R-06/9, prepared for the Ground Water Protection Council, October, 50 pp. Available at: http://www.ead.anl.gov/pub/dsp_detail.cfm?PubID=2027.

Veil, J.A., 2007, Panda Brandywine Power Plant site visit, April 17. 
WEF (Water Environment Federation), 2006, "Plant Profile - Clear Lake (Iowa) Sanitary District Treatment Plant," Water Environment \& Technology, vol 18, no. 10, October. Available at:

http://www.wef.org/ScienceTechnologyResources/Publications/WET/06Oct/06OctPlantProfile.h $\underline{\mathrm{tm}}$.

West Virginia Water Research Institute, 2004, "Strategies for Cooling Electrical Generating Facilities Utilizing Mine Water: Technical and Economic Feasibility,” Semi-annual Technical Progress Report, April, 37 pp. Available at: http://www.netl.doe.gov/technologies/coalpower/ewr/water/pp-mgmt/pubs/WVU.PDF.

Wright, P., 2007, personal communication between P. Wright, Pasco County Master Reuse System, New Port Richey, FL, and J. Veil, Argonne National Laboratory, March 22. Xcel Energy, undated $a$, "Harrington Station." Available at: http://www.xcelenergy.com/XLWEB/CDA/0,3080,1-1-1_1875_4797_4063-3613-0_0_0$\underline{0,00 . h t m l}$.

Xcel Energy, undated $b$, “Jones Station.” Available at: http://www.xcelenergy.com/XLWEB/CDA/0,3080,1-1-1_1875_4797_4063-3614-0_0_00,00.html.

Xcel Energy, undated $c$, "Nichols Station.” Available at: http://www.xcelenergy.com/XLWEB/CDA/0,3080,1-1-1_1875_4797_4063-3615-0_0_0$\underline{0,00 . h t m l}$. 


\section{Appendix A}

\section{Database of Power Plants Using Reclaimed Water (Listed by State)}




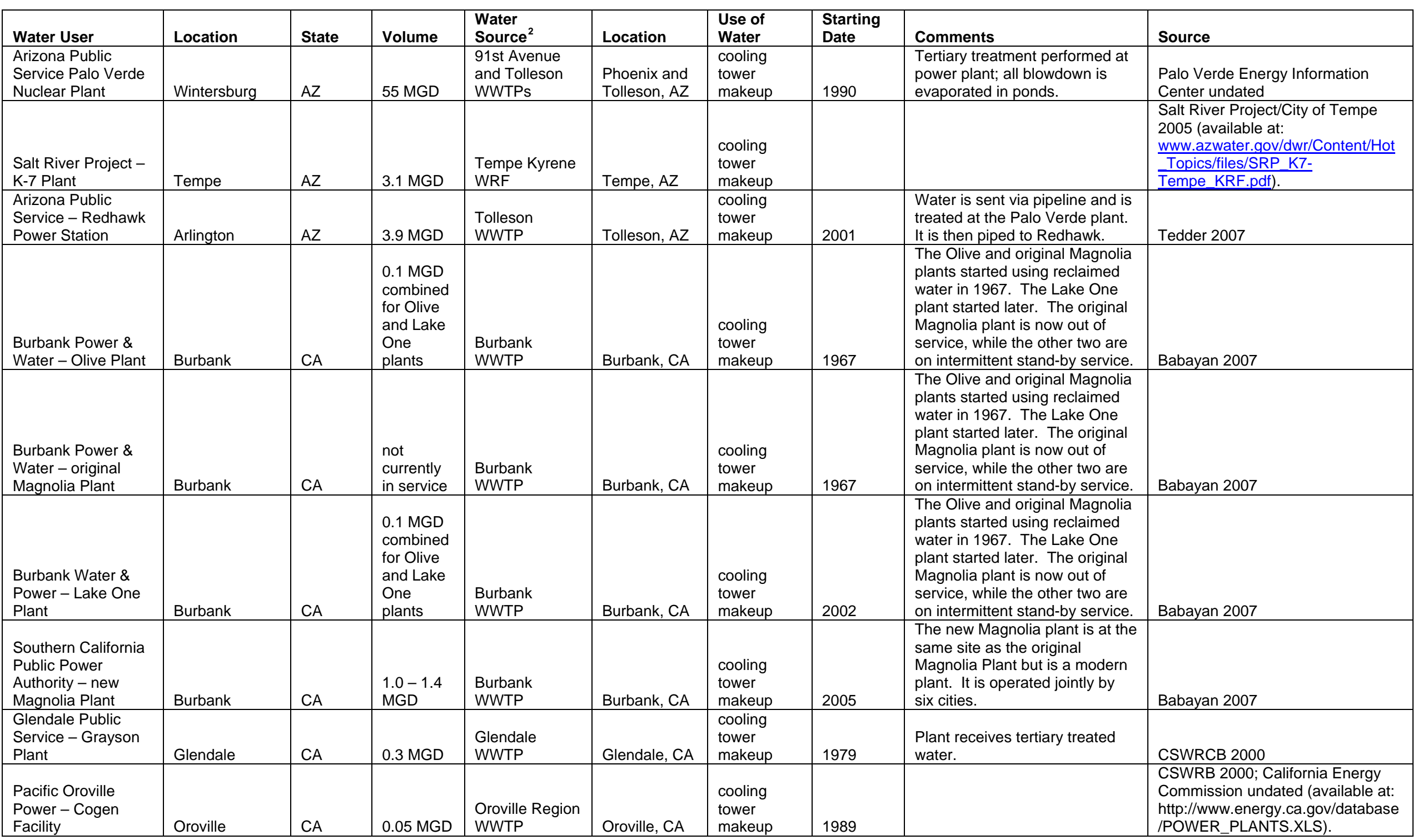

\footnotetext{
${ }^{2} \mathrm{WWTP}=$ wastewater treatment plant, WRF = water reclamation facility, and WPCF = water pollution control facility.
} 


\begin{tabular}{|c|c|c|c|c|c|c|c|c|c|}
\hline Water User & Location & State & Volume & $\begin{array}{l}\text { Water } \\
\text { Source }^{2}\end{array}$ & Location & $\begin{array}{l}\text { Use of } \\
\text { Water }\end{array}$ & $\begin{array}{l}\text { Starting } \\
\text { Date }\end{array}$ & Comments & Source \\
\hline $\begin{array}{l}\text { Spadra Gas-to- } \\
\text { Energy Plant }\end{array}$ & Pomona & $\mathrm{CA}$ & 0.03 MGD & Pomona WRF & Pomona, CA & $\begin{array}{l}\text { cooling } \\
\text { tower } \\
\text { makeup }\end{array}$ & 1991 & $\begin{array}{l}\text { Plant burns gas from a closed } \\
\text { landfill to generate power. }\end{array}$ & $\begin{array}{l}\text { CSWRB 2000; California Energy } \\
\text { Commission undated (available at: } \\
\text { http://www.energy.ca.gov/database } \\
\text { /POWER_PLANTS.XLS). }\end{array}$ \\
\hline $\begin{array}{l}\text { Puente Hills Energy } \\
\text { Recovery Plant }\end{array}$ & Whittier & $\mathrm{CA}$ & 0.5 MGD & $\begin{array}{l}\text { San Jose } \\
\text { Creek WRP }\end{array}$ & $\begin{array}{l}\text { near Whittier, } \\
\text { CA }\end{array}$ & $\begin{array}{l}\text { cooling } \\
\text { tower } \\
\text { makeup }\end{array}$ & 1984 & $\begin{array}{l}\text { Plant burns gas from a closed } \\
\text { landfill to generate power. }\end{array}$ & $\begin{array}{l}\text { CSWRB 2000; California Energy } \\
\text { Commission undated (available at: } \\
\text { http://www.energy.ca.gov/database } \\
\text { /POWER_PLANTS.XLS). }\end{array}$ \\
\hline $\begin{array}{l}\text { Northern CA Power } \\
\text { Agency - CT2 } \\
\text { Project }\end{array}$ & Lodi & $\mathrm{CA}$ & $0.08 \mathrm{MGD}$ & $\begin{array}{l}\text { White Slough } \\
\text { WPCF }\end{array}$ & Lodi, CA & boiler feed & 1996 & & $\begin{array}{l}\text { CSWRB 2000; California Energy } \\
\text { Commission undated (available at: } \\
\text { http://www.energy.ca.gov/database } \\
\text { /POWER_PLANTS.XLS). }\end{array}$ \\
\hline Delta Energy Center & Pittsburg & $\mathrm{CA}$ & $\begin{array}{l}7.7 \text { MGD } \\
\text { - total for } \\
\text { Delta and } \\
\text { Los } \\
\text { Medanos } \\
\text { Energy } \\
\text { Centers }\end{array}$ & $\begin{array}{l}\text { Delta Diablo } \\
\text { Sanitation } \\
\text { District } \\
\text { reclamation } \\
\text { plant }\end{array}$ & Antioch, CA & $\begin{array}{l}\text { cooling } \\
\text { tower } \\
\text { makeup }\end{array}$ & 2001 & & $\begin{array}{l}\text { Delta Diablo Sanitation District } \\
2001 \text { (available at: } \\
\text { http://www.ddsd.org/pdfs/RWF Bro } \\
\text { chure.pdf). }\end{array}$ \\
\hline $\begin{array}{l}\text { Los Medanos } \\
\text { Energy Center }\end{array}$ & Pittsburg & $\mathrm{CA}$ & $\begin{array}{l}7.7 \text { MGD } \\
\text { - total for } \\
\text { Delta and } \\
\text { Los } \\
\text { Medanos } \\
\text { Energy } \\
\text { Centers }\end{array}$ & $\begin{array}{l}\text { Delta Diablo } \\
\text { Sanitation } \\
\text { District } \\
\text { reclamation } \\
\text { plant }\end{array}$ & Antioch, CA & $\begin{array}{l}\text { cooling } \\
\text { tower } \\
\text { makeup }\end{array}$ & 2001 & & $\begin{array}{l}\text { Delta Diablo Sanitation District } \\
2001 \text { (available at: } \\
\text { http://www.ddsd.org/pdfs/RWF Bro } \\
\text { chure.pdf). }\end{array}$ \\
\hline $\begin{array}{l}\text { Geysers geothermal } \\
\text { field - } 19 \text { Calpine } \\
\text { geothermal power } \\
\text { plants and several } \\
\text { others operated by } \\
\text { the Northern } \\
\text { California Power } \\
\text { Agency }\end{array}$ & Santa Rosa & $\mathrm{CA}$ & 11 MGD & $\begin{array}{l}\text { Santa Rosa } \\
\text { WRF }\end{array}$ & $\begin{array}{l}\text { Santa Rosa, } \\
\text { CA }\end{array}$ & $\begin{array}{l}\text { injected to } \\
\text { maintain } \\
\text { geothermal } \\
\text { steam } \\
\text { pressure }\end{array}$ & 2003 & $\begin{array}{l}\text { This project will transport } \\
11 \text { million gallons of tertiary- } \\
\text { treated reclaimed water from the } \\
\text { City of Santa Rosa to the } \\
\text { northwestern part of the } \\
\text { Geysers steam field, where it } \\
\text { will be injected in the } \\
\text { geothermal reservoir. }\end{array}$ & $\begin{array}{l}\text { GRDA and California Energy } \\
\text { Commission undated (available at: } \\
\text { http://www.energy.ca.gov/geotherm } \\
\text { al/fact sheets/geothermal projects/ } \\
\text { SANTA ROSE RECLAIMED H2O. } \\
\text { PDF). }\end{array}$ \\
\hline $\begin{array}{l}\text { Geysers geothermal } \\
\text { field - } 19 \text { Calpine } \\
\text { geothermal power } \\
\text { plants and several } \\
\text { others operated by } \\
\text { the Northern } \\
\text { California Power } \\
\text { Agency }\end{array}$ & Lake County & $\mathrm{CA}$ & $8 \mathrm{MGD}$ & $\begin{array}{l}\text { Middletown, } \\
\text { Southeast } \\
\text { Regional, } \\
\text { Northwest } \\
\text { Regional, and } \\
\text { Clearlake Oaks } \\
\text { WWTPs }\end{array}$ & $\begin{array}{l}\text { Lake County, } \\
\text { CA }\end{array}$ & $\begin{array}{l}\text { injected to } \\
\text { maintain } \\
\text { geothermal } \\
\text { steam } \\
\text { pressure }\end{array}$ & 1997 & $\begin{array}{l}\text { This is a coordinated project to } \\
\text { pipe reclaimed water from } \\
\text { several WWTPs to a reservoir } \\
\text { adjacent to the Geysers } \\
\text { geothermal field. The water is } \\
\text { injected to increase steam } \\
\text { production. }\end{array}$ & $\begin{array}{l}\text { Lake County California undated } \\
\text { (available at: } \\
\text { http://www.co.lake.ca.us/Governme } \\
\text { nt/DepartmentDirectory/Special_Di } \\
\text { stricts/Wastewater_Systems/Efflue } \\
\text { nt Pipeline.htm). }\end{array}$ \\
\hline $\begin{array}{l}\text { Platte River Power } \\
\text { Authority - Rawhide } \\
\text { Energy Station }\end{array}$ & Wellington & $\mathrm{CO}$ & 3.8 MGD & Drake WRF & $\begin{array}{l}\text { Ft. Collins, } \\
\text { CO }\end{array}$ & cooling & 1984 & $\begin{array}{l}\text { The reclaimed water is piped to } \\
\text { a } 500 \text {-acre cooling pond at the } \\
\text { Rawhide site; the cooling pond } \\
\text { operates as a recirculating } \\
\text { cooling system. }\end{array}$ & $\begin{array}{l}\text { EPA 2004; fc.gov } 2007 \text { (available } \\
\text { at: http://fcgov.com/wastewater/ } \\
\text { facilities.php); Platte River Power } \\
\text { Authority 2007 (available at: } \\
\text { http://prpa.org/energysources/rawhi } \\
\text { dehistory.htm). }\end{array}$ \\
\hline
\end{tabular}




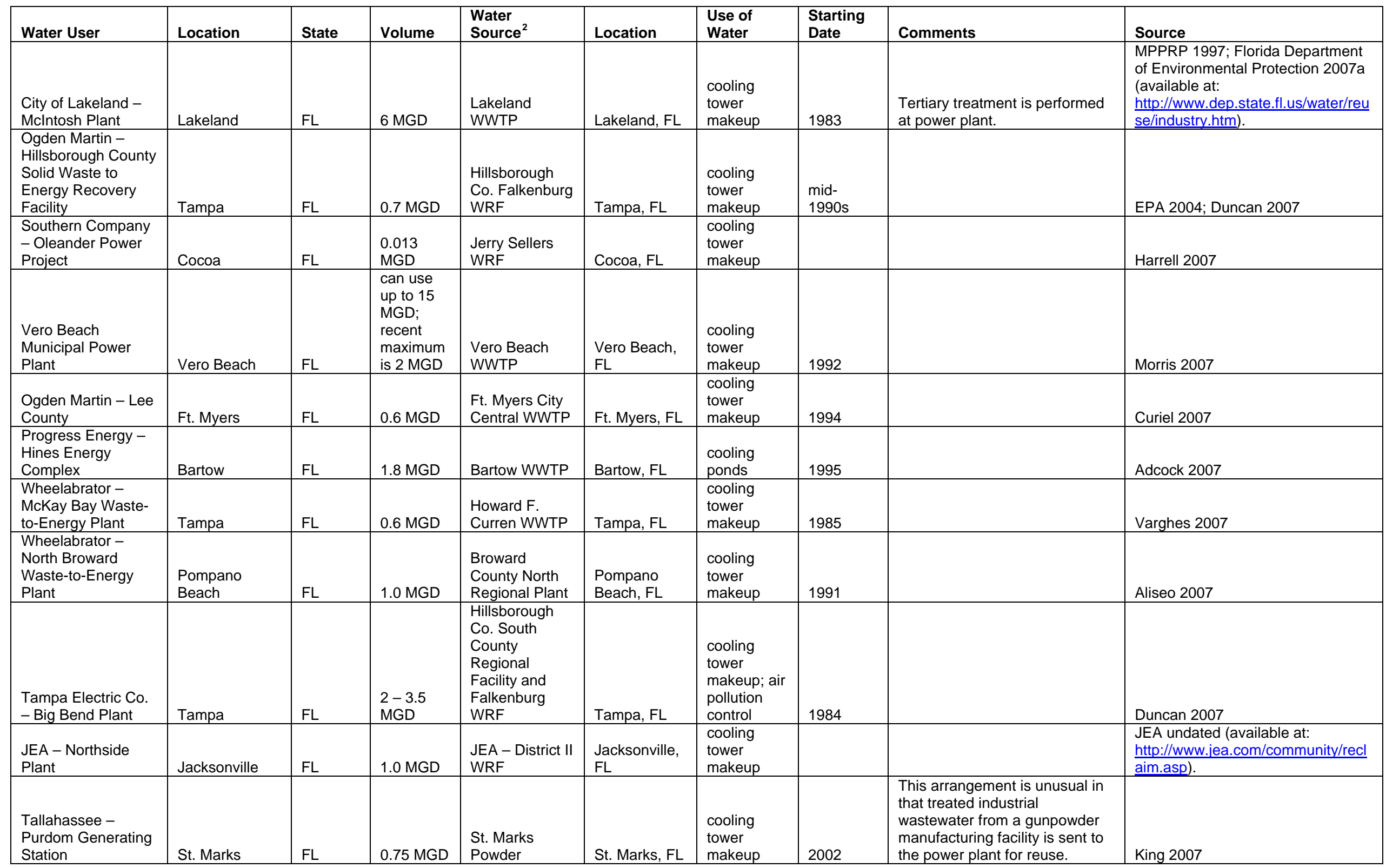




\begin{tabular}{|c|c|c|c|c|c|c|c|c|c|}
\hline Water User & Location & State & Volume & $\begin{array}{l}\text { Water } \\
\text { Source }^{2}\end{array}$ & Location & $\begin{array}{l}\text { Use of } \\
\text { Water }\end{array}$ & $\begin{array}{l}\text { Starting } \\
\text { Date }\end{array}$ & Comments & Source \\
\hline $\begin{array}{l}\text { Pasco County } \\
\text { Resource Recovery } \\
\text { Facility }\end{array}$ & Spring Hill & $\mathrm{FL}$ & $0.2 \mathrm{MGD}$ & $\begin{array}{l}\text { Pasco County } \\
\text { Master Reuse } \\
\text { System }\end{array}$ & $\begin{array}{l}\text { Pasco Co., } \\
\text { FL }\end{array}$ & $\begin{array}{l}\text { cooling } \\
\text { tower } \\
\text { makeup }\end{array}$ & $\begin{array}{l}\text { mid- } \\
1990 s\end{array}$ & $\begin{array}{l}\text { The county combines reclaimed } \\
\text { water from several treatment } \\
\text { plants into a combined county- } \\
\text { wide system. }\end{array}$ & Wright 2007 \\
\hline $\begin{array}{l}\text { Orlando Utilities - } \\
\text { C.H. Stanton Plant }\end{array}$ & Orlando & $\mathrm{FL}$ & $\begin{array}{l}10-11 \\
\text { MGD }\end{array}$ & Eastern WRF & Orlando, FL & $\begin{array}{l}\text { cooling } \\
\text { tower } \\
\text { makeup }\end{array}$ & 1987 & & EPA 2004; Castro 2007 \\
\hline $\begin{array}{l}\text { Kissimmee Utility } \\
\text { Authority - Cane } \\
\text { Island Plant }\end{array}$ & Kissimmee & $\mathrm{FL}$ & $\begin{array}{l}1-2.3 \\
M G D\end{array}$ & $\begin{array}{l}\text { South } \\
\text { Bermuda WRF } \\
\text { and Camelot } \\
\text { WRF }\end{array}$ & $\begin{array}{l}\text { Kissimmee, } \\
\mathrm{FL}\end{array}$ & $\begin{array}{l}\text { cooling } \\
\text { tower } \\
\text { makeup }\end{array}$ & 1990s & $\begin{array}{l}\text { Two water reclamation plants } \\
\text { combine reclaimed water into a } \\
\text { long pipeline. Two separate } \\
\text { power plants use portions of the } \\
\text { water. }\end{array}$ & Burton 2007 \\
\hline $\begin{array}{l}\text { Progress Energy - } \\
\text { Intercession City } \\
\text { Plant }\end{array}$ & Kissimmee & $\mathrm{FL}$ & $\begin{array}{l}0.03-0.2 \\
\text { MGD }\end{array}$ & $\begin{array}{l}\text { South } \\
\text { Bermuda WRF } \\
\text { and Camelot } \\
\text { WRF }\end{array}$ & $\begin{array}{l}\text { Kissimmee, } \\
\text { FL }\end{array}$ & $\begin{array}{l}\text { air pollution } \\
\text { control }\end{array}$ & $1990 \mathrm{~s}$ & $\begin{array}{l}\text { Two water reclamation plants } \\
\text { combine reclaimed water into a } \\
\text { long pipeline. Two separate } \\
\text { power plants use portions of the } \\
\text { water. }\end{array}$ & Burton 2007 \\
\hline $\begin{array}{l}\text { Progress Energy } \\
\text { Cogeneration Plant } \\
\text { - Univ. of Florida }\end{array}$ & Gainesville & $\mathrm{FL}$ & $0.4 \mathrm{MGD}$ & $\begin{array}{l}\text { Univ. of Florida } \\
\text { WWTP }\end{array}$ & $\begin{array}{l}\text { Gainesville, } \\
\text { FL }\end{array}$ & $\begin{array}{l}\text { cooling } \\
\text { tower } \\
\text { makeup }\end{array}$ & 1994 & & $\begin{array}{l}\text { UF Office of Sustainability } 2006 \\
\text { (available at: } \\
\text { http://www.sustainable.ufl.edu/oper } \\
\text { ationdetails.asp?op=9); Florida } \\
\text { Department of Environmental } \\
\text { Protection 2007a (available } \\
\text { at:http://www.dep.state.fl.us/water/r } \\
\text { euse/industry.htm). }\end{array}$ \\
\hline $\begin{array}{l}\text { Pinellas County } \\
\text { Utilities - Waste-to- } \\
\text { Energy Plant }\end{array}$ & St. Petersburg & $\mathrm{FL}$ & 1.7 MGD & $\begin{array}{l}\text { City of Largo } \\
\text { WWTP }\end{array}$ & Largo, FL & $\begin{array}{l}\text { cooling } \\
\text { tower } \\
\text { makeup }\end{array}$ & $\begin{array}{l}\text { early } \\
1990 \text { s }\end{array}$ & & Black 2007 \\
\hline Alliant Energy & Clear Lake & IA & 1.3 MGD & $\begin{array}{l}\text { Clear Lake } \\
\text { Sanitary } \\
\text { District }\end{array}$ & $\begin{array}{l}\text { Clear Lake, } \\
\text { IA }\end{array}$ & $\begin{array}{l}\text { cooling } \\
\text { tower } \\
\text { makeup }\end{array}$ & 2003 & $\begin{array}{l}\text { Company paid for WWTP } \\
\text { upgrades to tertiary quality. 60- } \\
80 \% \text { of the water is evaporated } \\
\text { and the blowdown is sent back } \\
\text { to the WWTP. }\end{array}$ & WEF 2006 \\
\hline $\begin{array}{l}\text { Sunflower Electric - } \\
\text { Garden City Plant }\end{array}$ & Garden City & KS & $0.5 \mathrm{MGD}$ & Garden City & $\mathrm{KS}$ & $\begin{array}{l}\text { cooling } \\
\text { tower } \\
\text { makeup }\end{array}$ & 2007 (?) & $\begin{array}{l}\text { They will use } 90 \% \text { treated } \\
\text { sewage and } 10 \% \text { well water. }\end{array}$ & Carlson 2007 \\
\hline $\begin{array}{l}\text { Wheelabrator - } \\
\text { North Andover } \\
\text { Waste-to-Energy } \\
\text { Plant }\end{array}$ & North Andover & MA & $\begin{array}{l}0.50 .65 \\
M G D\end{array}$ & $\begin{array}{l}\text { Greater } \\
\text { Lawrence } \\
\text { Sanitation } \\
\text { District }\end{array}$ & $\begin{array}{l}\text { North } \\
\text { Andover, MA }\end{array}$ & $\begin{array}{l}\text { cooling } \\
\text { tower } \\
\text { makeup }\end{array}$ & 1985 & & Marrinan 2007 \\
\hline Brayton Point & Somerset & MA & 1.3 MGD & $\begin{array}{l}\text { Somerset } \\
\text { water pollution } \\
\text { control plant }\end{array}$ & $\begin{array}{l}\text { Somerset, } \\
\text { MA }\end{array}$ & scrubber & $\begin{array}{l}2008 \\
\text { estimated }\end{array}$ & & $\begin{array}{l}\text { Metropolitan Area Planning Council } \\
2005\end{array}$ \\
\hline $\begin{array}{l}\text { Millennium Power } \\
\text { Partners }\end{array}$ & Charlton & MA & $0.4 \mathrm{MGD}$ & $\begin{array}{l}\text { Southbridge } \\
\text { WWTP }\end{array}$ & $\begin{array}{l}\text { Southbridge, } \\
\text { MA }\end{array}$ & $\begin{array}{l}\text { cooling } \\
\text { tower } \\
\text { makeup }\end{array}$ & $\sim 2004$ & & $\begin{array}{l}\text { Metropolitan Area Planning Council } \\
\text { 2005; Grenier } 2007\end{array}$ \\
\hline
\end{tabular}




\begin{tabular}{|c|c|c|c|c|c|c|c|c|c|}
\hline Water User & Location & State & Volume & $\begin{array}{l}\text { Water } \\
\text { Source }^{2}\end{array}$ & Location & $\begin{array}{l}\text { Use of } \\
\text { Water }\end{array}$ & $\begin{array}{l}\text { Starting } \\
\text { Date }\end{array}$ & Comments & Source \\
\hline Panda-Brandywine & Brandywine & MD & 1.5 MGD & $\begin{array}{l}\text { Mattawoman } \\
\text { WWTP }\end{array}$ & $\begin{array}{l}\text { Mason } \\
\text { Springs, MD }\end{array}$ & $\begin{array}{l}\text { cooling } \\
\text { tower } \\
\text { makeup }\end{array}$ & 1997 & $\begin{array}{l}\text { The reclaimed water is sent } \\
\text { through a } 17 \text {-mile pipeline. }\end{array}$ & MPPRP 1997 \\
\hline $\begin{array}{l}\text { Bethlehem Steel - } \\
\text { Sparrows Pt. }\end{array}$ & Baltimore & MD & $\begin{array}{l}\text { see } \\
\text { comments }\end{array}$ & $\begin{array}{l}\text { Back River } \\
\text { WWTP }\end{array}$ & $\begin{array}{l}\text { Baltimore, } \\
\text { MD }\end{array}$ & process & $\begin{array}{l}\text { early } \\
1970 \text { s }\end{array}$ & $\begin{array}{l}\text { Bethlehem Steel was sold under } \\
\text { bankruptcy in 2003; the } \\
\text { reclaimed water volume, at one } \\
\text { time } 100 \text { MGD, is greatly } \\
\text { decreased now because of steel } \\
\text { mill downsizing }\end{array}$ & EPA 2004 \\
\hline $\begin{array}{l}\text { Caledonia } \\
\text { Operating Services } \\
\text { - Caledonia Plant } \\
\end{array}$ & Steens & MS & $0.5 \mathrm{MGD}$ & $\begin{array}{l}\text { Columbus } \\
\text { Light and } \\
\text { Water WWTP }\end{array}$ & $\begin{array}{l}\text { Columbus, } \\
\text { MS }\end{array}$ & & $\begin{array}{l}\text { some time } \\
\text { after } 2002\end{array}$ & & $\begin{array}{l}\text { Barksdale 2007; Cogentrix Energy, } \\
\text { Inc., undated (available at: } \\
\text { http://ww.willbros.com/ filelib/FileC } \\
\text { abinet/Projects/North America/Cal } \\
\text { edonia\%20Water.pdf?FileName }=0 \\
\text { 108.pdf). }\end{array}$ \\
\hline $\begin{array}{l}\text { AES - Granite } \\
\text { Ridge Plant }\end{array}$ & Londonderry & $\mathrm{NH}$ & 4 MGD & $\begin{array}{l}\text { Manchester } \\
\text { WWTP }\end{array}$ & $\begin{array}{l}\text { Manchester, } \\
\mathrm{NH}\end{array}$ & $\begin{array}{l}\text { cooling } \\
\text { tower } \\
\text { makeup }\end{array}$ & 2002 & & $\begin{array}{l}\text { NH Society of Professional } \\
\text { Engineers } 2002\end{array}$ \\
\hline $\begin{array}{l}\text { PSEG - Linden } \\
\text { Station }\end{array}$ & Linden & $\mathrm{NJ}$ & $12 \mathrm{MGD}$ & $\begin{array}{l}\text { Linden/Roselle } \\
\text { Sewage } \\
\text { Authority }\end{array}$ & Linden, $\mathrm{NJ}$ & $\begin{array}{l}\text { cooling } \\
\text { tower } \\
\text { makeup }\end{array}$ & 2006 & $\begin{array}{l}\text { Plant provides additional } \\
\text { treatment before using. Any } \\
\text { unused water is returned to the } \\
\text { WWTP. }\end{array}$ & EIA 2005; Power Magazine 2006 \\
\hline $\begin{array}{l}\text { PSEG - Bergen } \\
\text { Station }\end{array}$ & Ridgefield & NJ & $0.6 \mathrm{MGD}$ & $\begin{array}{l}\text { Bergen County } \\
\text { Utilities } \\
\text { Authority } \\
\text { WWTP }\end{array}$ & $\begin{array}{l}\text { Little Ferry, } \\
\text { NJ }\end{array}$ & $\begin{array}{l}\text { cooling } \\
\text { tower } \\
\text { makeup }\end{array}$ & 2002 & & $\begin{array}{l}\text { Bergen County Utilities Authority } \\
2006 \text { (available at: } \\
\text { http://www.bcua.org/WPC VT Wa } \\
\text { steWaterReUse.htm). }\end{array}$ \\
\hline $\begin{array}{l}\text { PNM - Luna Energy } \\
\text { Facility }\end{array}$ & Deming & NM & $1 \mathrm{MGD}$ & Deming WWTP & Deming, NM & $\begin{array}{l}\text { cooling } \\
\text { tower } \\
\text { makeup }\end{array}$ & 2007 & $\begin{array}{l}\text { Plant commissioned in } 4 / 06 \text { but } \\
\text { filtration system failed. The } \\
\text { company's plan was to } \\
\text { recommission in the spring of } \\
2007 \text {. }\end{array}$ & Lavery 2007 \\
\hline $\begin{array}{l}\text { Nevada Power } \\
\text { Company - Clark } \\
\text { Station }\end{array}$ & Henderson & NV & $\begin{array}{l}\text { varies } \\
\text { monthly - } \\
0.15 \text { to } \\
2.7 \text { MGD }\end{array}$ & $\begin{array}{l}\text { Clark County } \\
\text { Water } \\
\text { Reclamation } \\
\text { District }\end{array}$ & $\begin{array}{l}\text { Las Vegas, } \\
\text { NV }\end{array}$ & $\begin{array}{l}\text { cooling } \\
\text { tower } \\
\text { makeup }\end{array}$ & & $\begin{array}{l}\text { The power company provides } \\
\text { additional treatment before use. }\end{array}$ & Morgan 2007 \\
\hline $\begin{array}{l}\text { Nevada Power } \\
\text { Company - Sunrise } \\
\text { Station }\end{array}$ & Las Vegas & NV & $\begin{array}{l}0.09-0.3 \\
M G D\end{array}$ & $\begin{array}{l}\text { Las Vegas } \\
\text { WPCF }\end{array}$ & $\begin{array}{l}\text { Las Vegas, } \\
\text { NV }\end{array}$ & $\begin{array}{l}\text { cooling } \\
\text { tower } \\
\text { makeup }\end{array}$ & $\begin{array}{l}\text { early } \\
1990 \text { s }\end{array}$ & & Miller 2007 \\
\hline $\begin{array}{l}\text { Lancaster County } \\
\text { Resource Recovery } \\
\text { Facility }\end{array}$ & Bainbridge & PA & $0.6 \mathrm{MGD}$ & $\begin{array}{l}\text { Elizabethtown } \\
\text { WWTP }\end{array}$ & $\begin{array}{l}\text { Elizabeth- } \\
\text { town, PA }\end{array}$ & $\begin{array}{l}\text { cooling } \\
\text { tower } \\
\text { makeup }\end{array}$ & 1991 & $\begin{array}{l}\text { The facility has holding ponds } \\
\text { with a } 2.5 \text { million gallon } \\
\text { capacity. }\end{array}$ & $\begin{array}{l}\text { LCSWMA undated (available at: } \\
\text { http://www.Icswma.org/resourceRe } \\
\text { covery.asp); EPA } 2004 .\end{array}$ \\
\hline $\begin{array}{l}\text { American National } \\
\text { Power - Hays } \\
\text { Energy Project }\end{array}$ & San Marcos & TX & $0.3 \mathrm{MGD}$ & San Marcos & $\begin{array}{l}\text { San Marcos, } \\
\text { TX }\end{array}$ & $\begin{array}{l}\text { cooling } \\
\text { tower } \\
\text { makeup }\end{array}$ & 2002 & & EPA 2004; Longoria et al. 2000 \\
\hline
\end{tabular}




\begin{tabular}{|c|c|c|c|c|c|c|c|c|c|}
\hline Water User & Location & State & Volume & $\begin{array}{l}\text { Water } \\
\text { Source }^{2}\end{array}$ & Location & $\begin{array}{l}\text { Use of } \\
\text { Water }\end{array}$ & $\begin{array}{l}\text { Starting } \\
\text { Date }\end{array}$ & Comments & Source \\
\hline $\begin{array}{l}\text { Garland Power \& } \\
\text { Light - Spencer } \\
\text { Road Power Plant }\end{array}$ & Denton & $\mathrm{TX}$ & 1.0 MGD & $\begin{array}{l}\text { Pecan Creek } \\
\text { WRF }\end{array}$ & Denton, $\mathrm{TX}$ & $\begin{array}{l}\text { cooling } \\
\text { tower } \\
\text { makeup }\end{array}$ & $\begin{array}{l}\text { mid- } \\
1970 \text { s }\end{array}$ & $\begin{array}{l}\text { Facility may have been shut } \\
\text { down in } 2002 \text {. }\end{array}$ & $\begin{array}{l}\text { City of Denton, Texas } 2003 \\
\text { (available at: } \\
\text { http://www.cityofdenton.com/pages/ } \\
\text { mygovewhitepaperssolidwwaterwat } \\
\text { er.cfm?object=3481\&folderlD=258 } \\
\text { \&action=files). }\end{array}$ \\
\hline $\begin{array}{l}\text { Xcel Energy - } \\
\text { Harrington Plant }\end{array}$ & Amarillo & $\mathrm{TX}$ & $\begin{array}{l}15 \text { MGD } \\
\text { split } \\
\text { between } \\
\text { Nichols } \\
\text { and } \\
\text { Harring- } \\
\text { ton }\end{array}$ & $\begin{array}{l}\text { Amarillo } \\
\text { WWTP }\end{array}$ & Amarillo, TX & $\begin{array}{l}\text { cooling } \\
\text { tower } \\
\text { makeup }\end{array}$ & & & 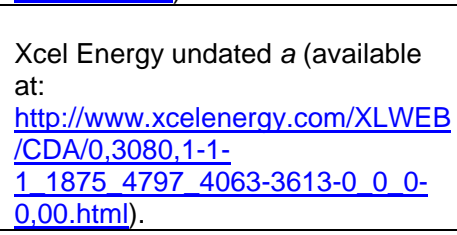 \\
\hline $\begin{array}{l}\text { Xcel Energy - } \\
\text { Jones Plant }\end{array}$ & Lubbock & $\mathrm{TX}$ & $\begin{array}{l}3-5 \\
M G D\end{array}$ & $\begin{array}{l}\text { Lubbock } \\
\text { WWTP }\end{array}$ & Lubbock, TX & $\begin{array}{l}\text { cooling } \\
\text { tower } \\
\text { makeup }\end{array}$ & & & 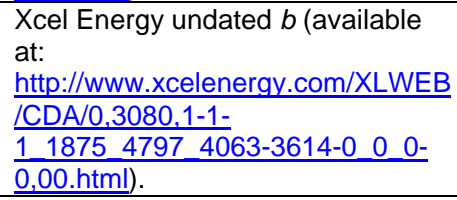 \\
\hline $\begin{array}{l}\text { Xcel Energy - } \\
\text { Nichols Plant }\end{array}$ & Amarillo & $\mathrm{TX}$ & $\begin{array}{l}15 \text { MGD } \\
\text { split } \\
\text { between } \\
\text { Nichols } \\
\text { and } \\
\text { Harring- } \\
\text { ton } \\
\end{array}$ & $\begin{array}{l}\text { Amarillo } \\
\text { WWTP }\end{array}$ & Amarillo, TX & $\begin{array}{l}\text { cooling } \\
\text { tower } \\
\text { makeup }\end{array}$ & & & 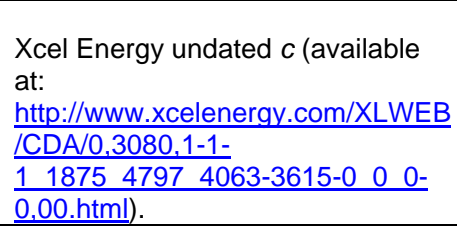 \\
\hline $\begin{array}{l}\text { El Paso Electric - } \\
\text { Newman Plant }\end{array}$ & El Paso & $\mathrm{TX}$ & 2.4 MGD & $\begin{array}{l}\text { El Paso Water } \\
\text { Utilities - Fred } \\
\text { Hervey WWTP }\end{array}$ & El Paso, TX & $\begin{array}{l}\text { cooling } \\
\text { tower } \\
\text { makeup }\end{array}$ & 1991 & & $\begin{array}{l}\text { Mauricio 2007; El Paso Water } \\
\text { Utilities } 2007 \text { (available at: } \\
\text { http://www.epwu.org/wastewater/fr } \\
\text { ed hervey reclaimation.html\#). }\end{array}$ \\
\hline $\begin{array}{l}\text { Suez Energy } \\
\text { Resources - Ennis- } \\
\text { Tractebel Plant } \\
\end{array}$ & Ennis & $\mathrm{TX}$ & $\begin{array}{l}1-1.5 \\
M G D\end{array}$ & $\begin{array}{l}\text { Oak Grove } \\
\text { WWTP }\end{array}$ & Ennis, TX & $\begin{array}{l}\text { cooling } \\
\text { tower } \\
\text { makeup }\end{array}$ & 2001 & & Hester 2007 \\
\hline $\begin{array}{l}\text { GE Energy - Fox } \\
\text { Energy Center }\end{array}$ & Kaukauna & WI & $0.8 \mathrm{MGD}$ & $\begin{array}{l}\text { Heart of the } \\
\text { Valley } \\
\text { Metropolitan } \\
\text { Sewerage } \\
\text { District }\end{array}$ & $\begin{array}{l}\text { Kaukauna, } \\
\text { WI }\end{array}$ & $\begin{array}{l}\text { cooling } \\
\text { tower } \\
\text { makeup }\end{array}$ & 2005 & $\begin{array}{l}\text { Use is intermittent - this is a } \\
\text { peaking plant with most use in } \\
\text { the summer. }\end{array}$ & Guerts 2007; Johnson 2007 \\
\hline
\end{tabular}




\section{Appendix B - Reclaimed Water Regulations for Arizona (Arizona Administrative Code 2007, available at: http://www.azsos.gov/public_services/Title_18/18- 11.htm)}

The Arizona Department of Environmental Quality has two separate sets of regulations relating to reclaimed water: Chapter 9 - Water Pollution Control, Article 7 and Chapter 11 - Water Quality Standards, Article 3. Selected portions of the text of both Articles follows.

\section{ARTICLE 7. DIRECT REUSE OF RECLAIMED WATER}

\section{R18-9-701. Definitions}

Unless provided otherwise, the definitions provided in A.R.S. § 49-201, A.A.C. R18-9-101, R18-9-601, R18-11301, and the following terms apply to this Article:

1. "Direct reuse" means the beneficial use of reclaimed water for a purpose allowed by this Article. The following is not a direct reuse of reclaimed water:

a. The use of water subsequent to its discharge under the conditions of a National Pollutant Discharge Elimination System permit;

b. The use of water subsequent to discharge under the conditions of an Aquifer Protection Permit issued under 18 A.A.C. 9, Articles 1 through 3; or

c. The use of industrial wastewater or reclaimed water, or both, in a workplace subject to a federal program that protects workers from workplace exposures.

2. "Direct reuse site" means an area permitted for the application or impoundment of reclaimed water. An impoundment operated for disposal under an Aquifer Protection Permit is not a direct reuse site.

3. "End user" means a person who directly reuses reclaimed water meeting the standards for Classes A+, A, B+, B, and C, established under 18 A.A.C. 11, Article 3.

4. "Gray water" means wastewater collected separately from a sewage flow that originates from a clothes washer, bathtub, shower, and sink, but does not include wastewater from a kitchen sink, dishwasher, or toilet.

5. "Industrial wastewater" means wastewater generated from an industrial process.

6. "Irrigation" means the beneficial use of water or reclaimed water, or both, for growing crops, turf, or silviculture, or for landscaping.

7. "Open access" means that access to reclaimed water by the general public is uncontrolled.

8. "Reclaimed water" means water that has been treated or processed by a wastewater treatment plant or an onsite wastewater treatment facility. A.R.S. § 49-201(31).

9. "Reclaimed water agent" means a person who holds a permit to distribute reclaimed water to more than one end user.

10. "Reclaimed water blending facility" means an installation or method of operation that receives reclaimed water from a sewage treatment facility or other reclaimed water blending facility classified to produce Class $\mathrm{C}$ or better reclaimed water and blends it with other water so that the produced water may be used for a higher-class purpose listed in 18 A.A.C. 11, Article 3, Appendix A.

11. "Restricted access" means that access to reclaimed water by the general public is controlled.

\section{R18-9-702. Applicability and Standards for Reclaimed Water Classes}

A. This Article applies to:

1. An owner or operator of a sewage treatment facility that generates reclaimed water for direct reuse,

2. An owner or operator of a reclaimed water blending facility,

3. A reclaimed water agent,

4. An end user,

5. A person who uses gray water,

6. A person who directly reuses reclaimed water from a sewage treatment facility combined with industrial wastewater or combined with reclaimed water from an industrial wastewater treatment facility, and

7. A person who directly reuses reclaimed water from an industrial wastewater treatment facility in the production or processing of a crop or substance that may be used as human or animal food.

B. Reclaimed water classes A+, A, B+, B, and C specified in this Article shall meet the standards established in 18 A.A.C. 11, Article 3.

C. Nothing in this Article exempts the disposal of reclaimed water from the Aquifer Protection Permit requirements under A.R.S. Title 49, Chapter 2, Articles 1, 2, and 3. 


\section{R18-9-704. General Requirements}

A. Sewage treatment facility. Except for permits continued under R18-9-703(A), a sewage treatment facility owner or operator shall provide reclaimed water for direct reuse only under an individual Aquifer Protection Permit amended under R18-9-703(C)(2).

B. Additional treatment. If an owner or operator of a facility accepts reclaimed water and provides additional treatment for a higher quality direct reuse, the facility is considered a sewage treatment facility and shall operate under the requirements of an individual Aquifer Protection Permit amended under R18-9-703(C)(2).

C. Reclaimed water blending facility. An owner or operator of a reclaimed water blending facility shall not conduct blending operations without obtaining a Reclaimed Water Individual Permit or Reclaimed Water General Permit.

D. Reclaimed water agent. A person shall not operate as a reclaimed water agent without obtaining a Reclaimed Water Individual Permit or a Reclaimed Water General Permit.

E. End user. A person shall not directly reuse reclaimed water unless permitted under this Article.

F. Irrigating with reclaimed water. A permittee irrigating with reclaimed water shall:

1. Use application methods that reasonably preclude human contact with reclaimed water;

2. Prevent reclaimed water from standing on open access areas during normal periods of use;

3. Prevent reclaimed water from coming into contact with drinking fountains, water coolers, or eating areas; and

4. Secure hose bibbs discharging reclaimed water to prevent use by the public.

G. Prohibited activities.

1. Irrigating with untreated sewage;

2. Providing or using reclaimed water for any of the following activities:

a. Direct reuse for human consumption;

b. Direct reuse for swimming, wind surfing, water skiing, or other full-immersion water activity with a potential of ingestion; or

c. Direct reuse for evaporative cooling or misting.

3. Misapplying reclaimed water for any of the following reasons:

a. Application of a stated class of reclaimed water that is of lesser quality than allowed by this Article for the type of direct reuse application;

b. Application of reclaimed water to any area other than a direct reuse site; or

c. Allowing runoff of reclaimed water or reclaimed water mixed with stormwater from a direct reuse site, except for agricultural return flow that is directed onto an adjacent field or returned to an open water conveyance.

H. A permittee shall place and maintain signage at locations specified in Table 1 so the public is informed that reclaimed water is in use and that no one should drink from the system.

\section{R18-9-705. Reclaimed Water Individual Permit Application}

A. Pre-application conference. Upon request of an applicant, the Department shall schedule and hold a preapplication conference with the applicant to discuss any requirements in this Article.

B. To apply for a Reclaimed Water Individual Permit, a person shall provide the Department with:

1. The following information on a form provided by the Department:

a. The name and mailing address of the owner or operator of the facility or the reclaimed water agent;

b. The social security number of the applicant, if the applicant is an individual;

c. The legal description of the direct reuse site, including latitude and longitude coordinates;

d. Any other federal or state environmental permits issued to the applicant;

e. Source of reclaimed water to be directly reused;

f. Volume of reclaimed water to be directly reused on an annual basis;

g. Class of reclaimed water to be directly reused;

h. Description of the direct reuse activity; and

i. The applicant's signature certifying that the information submitted in the application is true and accurate to the best of the applicant's knowledge.

2. A copy of the certificate of disclosure of violations required under A.R.S. § 49-109; and

3. The applicable permit fee specified under 18 A.A.C. 14.

C. Administrative completeness review. Upon receipt, the Department shall review the Reclaimed Water Individual Permit application to determine its administrative completeness under A.R.S. § 41-1074 and A.A.C. R18-1-503.

D. Substantive review. Upon receipt of a complete Reclaimed Water Individual Permit application, the Department shall review the application to determine its substantive adequacy under A.R.S. § 41-1075 and A.A.C. R18-1504. 
E. Draft permit. The Department shall provide the applicant a copy of a draft of the Reclaimed Water Individual Permit before the notice specified in subsection (F) is published.

F. Public participation.

1. Notice of Preliminary Decision.

a. The Department shall publish a Notice of Preliminary Decision to issue or deny a Reclaimed Water Individual Permit within a period of time that allows the Department to meet the licensing time-frame requirements under 18 A.A.C. 5.

b. The Department shall publish the Notice of Preliminary Decision regarding the issuance or denial of a final permit determination in one or more newspapers of general circulation where the facility is located.

c. The Department shall accept written comments from the public before a Reclaimed Water Individual Permit is issued or denied.

d. The written public comment period begins on the publication date of the Notice of Preliminary Decision and extends for 30 calendar days.

2. After publishing the notice specified in subsection (F)(1)(a), the Department shall hold a public hearing to address the Notice of Preliminary Decision if the Department determines that:

a. Public interest in a public hearing exists, or

b. Issues or information have been brought to the attention of the Department that are relevant to the permitting decision and have not been considered previously in the permitting process.

3. If the Department determines that a public hearing is necessary and a public hearing has not already been noticed under subsection (F)(1)(a), the Department shall schedule a public hearing and republish the Notice of Preliminary Decision as a legal notice at least once, in one or more newspapers of general circulation where the facility is located.

4. The Department shall accept written public comment until the close of the hearing record as specified by the person presiding at the public hearing.

G. Final permit issuance or denial.

1. The Department shall give the applicant written notification of its final decision to issue or deny the permit application within the overall licensing time-frame requirements in 18 A.A.C. 5.

2. The Department may deny a Reclaimed Water Individual Permit if the Department determines upon completion of the application process that the applicant has:

a. Failed or refused to correct a deficiency in the permit application;

b. Failed to demonstrate that the facility and the operation will protect public health and water quality. This determination shall be based on:

i. The information submitted in the permit application,

ii. Any information submitted to the Department as written public comment or following a public hearing; or

iii. Any information relevant to the demonstration that is developed or acquired by the Department, or c. Provided false or misleading information.

3. If the Department denies a Reclaimed Water Individual Permit the Department shall provide the applicant with written notification that explains the following:

a. The reasons for the denial with references to the statutes or rules on which the denial is based.

b. The applicant's right to appeal the denial, including the number of days the applicant has to file a notice of appeal, and the name and telephone number of the Department contact person who can answer questions regarding the appeals process.

c. The applicant's right to request an informal settlement conference under A.R.S. §§ 41-1092.03(A) and 41-1092.06.

R18-9-706. Reclaimed Water Individual Permit General Provisions

A. A Reclaimed Water Individual Permit obtained under R18-9-705:

1. Is valid for five years;

2. May be amended, transferred, reissued, or revoked by the Director based on whether the permittee meets the terms of the individual permit and the requirements of this Article; and

3. Continues, pending the issuance of a new permit, with the same terms following its expiration if the following are met:

a. The permittee submits an application for a new permit at least 120 days before the expiration of the existing permit; and

b. The permitted activity is of a continuing nature.

B. A Reclaimed Water Individual Permit shall contain, if applicable:

1 . The class of reclaimed water to be applied for direct reuse; 
2. Specific reuse applications or limitations on reuse;

3. Requirements for monitoring reclaimed water quality and flow to demonstrate compliance with this Article and 18 A.A.C. 11, Article 3;

4. Requirements for reporting the following data to demonstrate compliance with this Article and 18 A.A.C. 11, Article 3:

a. Water quality test results demonstrating that the reclaimed water meets the applicable standards for the class of water identified in subsection (B)(1), and

b. The total volume of reclaimed water generated for direct reuse.

5. Requirements for maintaining records of all monitoring information and monitoring activities that include:

a. The date, description of sampling location, and time of sampling or measurement;

b. The name of the person who performed the sampling or measurement;

c. The date the analyses were performed;

d. The name of the person who performed the analyses;

e. The analytical techniques or methods used;

$\mathrm{f}$. The results of the analyses; and

g. Documentation of sampling technique, sample preservation, and transportation, including chain-ofcustody forms.

6. Requirements to retain all monitoring activity records and results, including all original strip chart recordings for continuous monitoring instrumentation, and calibration and maintenance records for five years from the date of sampling or analysis. The Director shall extend the five-year retention period:

a. During the course of an unresolved litigation regarding compliance with the permit conditions, or

b. For any other justifiable cause.

7. A requirement to allow all end users access to the records of physical, chemical, and biological quality of the reclaimed water.

C. Permit transfer. A permittee may transfer a Reclaimed Water Individual Permit to another person if the following conditions are met:

1. The permittee notifies the Director of the proposed transfer.

2. The permittee submits a written agreement containing a specific date for the transfer of permit responsibility and coverage between the current permittee and the proposed new permittee, including an acknowledgment that the existing permittee is liable for violations up to the date of transfer and that the proposed new permittee will be liable for violations from that date forward.

3. The notice specified in subsection (C)(1) contains any information for the proposed new permittee that is changed from the information submitted under R18-9-705(B).

4. The Director, within 30 days of receiving a transfer notice from the permittee, does not notify both the current permittee and proposed new permittee of the intent to amend, revoke, or reissue the permit or require the proposed new permittee to file an application for a new permit rather than agreeing to transfer the current permit.

R18-9-707. Reclaimed Water Individual Permit Where Industrial Wastewater Influences the Characteristics of Reclaimed Water

A. The following activities are prohibited unless a Reclaimed Water Individual Permit is obtained under R18-9-705:

1. Direct reuse of reclaimed water from a sewage treatment facility that is combined with industrial wastewater or that is combined with reclaimed water from an industrial wastewater treatment facility.

2. Direct reuse of reclaimed water from an industrial wastewater treatment facility for production or processing of a crop or substance that may be used as human or animal food.

B. In addition to the requirements in R18-9-705(B), an application for a Reclaimed Water Individual Permit shall include:

1. Each source of the industrial wastewater with Standard Industrial Code, and the projected rates and volumes from each source;

2. The chemical, biological, and physical characteristics of the industrial wastewater from each source; and

3. If reclaimed water will be used in the processing of any crop or substance that may be used as human or animal food, the information regarding food safety and any potential adverse health effects of this direct reuse.

\section{R18-9-708. Reusing Reclaimed Water Under a General Permit}

A. Type 1 Reclaimed Water General Permit. A person may directly reuse reclaimed water without notice to the

Department if:

1. The direct reuse is specifically authorized by and meets the requirements of this Article, and

2. Complies with the requirements of the Type 1 Reclaimed Water General Permit under R18-9-711.

B. Type 2 Reclaimed Water General Permit. 
1. A person may directly reuse reclaimed water under a Type 2 Reclaimed Water General Permit if:

a. The direct reuse is authorized by and meets the requirements of this Article;

b. The direct reuse meets all the conditions of the applicable Type 2 Reclaimed Water General Permit under R18-9-712 through R18-9-716;

c. The person files a Notice of Intent for Direct Reuse of Reclaimed Water under subsection (B)(2); and

d. The person submits the applicable fee established in 18 A.A.C. 14.

2. Notice of Intent for Direct Reuse of Reclaimed Water.

a. A person shall submit, by certified mail, in person, or by another method approved by the Department, the Notice of Intent for Direct Reuse of Reclaimed Water on a form provided by the Department.

b. The Notice of Intent for Direct Reuse of Reclaimed Water shall include;

i. The name, address, and telephone number of the applicant;

ii. The social security number of the applicant, if the applicant is an individual;

iii. The name, address, and telephone number of the contact person;

iv. The source, volume, and class of reclaimed water to be directly reused;

v. A legal description of the direct reuse site, including latitude and longitude coordinates;

vi. The description of the direct reuse activity, including a description of acreage and the type of

vegetation to be irrigated, if applicable to the type of direct reuse activity; and

vii. The permittee's signature certifying that the permittee agrees to comply with all requirements of

this Article, including specific terms of the applicable Reclaimed Water General Permit.

C. Type 3 Reclaimed Water General Permit. A person may operate under a Type 3 Reclaimed Water General Permit after filing an applicable Notice of Intent to Operate with the Department and receiving a written Verification of General Permit Conformance for the operation.

1. Application submittal. The applicant shall submit, either by certified mail, in person at the Department, or by another method approved by the Department:

a. The Notice of Intent to Operate on a form provided by the Department containing the information

specified in the applicable Type 3 Reclaimed Water General Permit under R18-9-717(B), R18-9-

718(C), or R18-9-719(B), and

b. The applicable fee established in 18 A.A.C. 14.

2. Verification issuance. If, after reviewing the Notice of Intent to Operate, the Department determines that the direct reuse conforms with the conditions of a Type 3 Reclaimed Water General Permit and all other applicable requirements of this Article, the Department shall issue the Verification of General Permit Conformance.

3. Verification denial.

a. If the Department determines on the basis of its review or an inspection that the direct reuse does not conform to the conditions of the applicable Type 3 Reclaimed Water General Permit or other applicable requirements of this Article, the Department shall notify the applicant of its decision not to issue the Verification of General Permit Conformance.

b. If an application is denied, the applicant shall not operate under a Type 3 Reclaimed Water General Permit.

c. The applicant may appeal the decision not to issue a Verification of General Permit Conformance under A.R.S. §§ 41-1092 through 41-1092.12.

4. Automatic issuance. If the Department does not issue the Verification of General Permit Conformance within the time-frame specified under 18 A.A.C. 1, Article 5, and does not notify the applicant that it will not issue the verification, the verification automatically becomes effective upon expiration of the overall time-frame.

\section{R18-9-709. Reclaimed Water General Permit Renewal and Transfer}

A. General permit renewal. A permittee shall renew a Reclaimed Water General Permit at least 90 days before the permit expires by following the procedure described in either R18-9-708(B) or (C) and include the applicable fee established in 18 A.A.C. 14.

1. A Type 1 Reclaimed Water General Permit is valid as long as the conditions of the general permit and the requirements of this Article are met. No renewal is required;

2. A Type 2 Reclaimed Water General Permit is valid for five years from the date the Department receives the Notice of Intent for Direct Reuse of Reclaimed Water;

3. A Type 3 Reclaimed Water General Permit is valid for five years from the date the Verification of General Permit Conformance becomes effective.

B. General permit transfer. A permittee shall provide notice to the Department by certified mail within 15 days following the transfer of a Type 2 or Type 3 Reclaimed Water General Permit. The Notice of Transfer shall: 
1. Contain any information that has changed from the original Notice of Intent for Direct Reuse of Reclaimed Water or the Notice of Intent to Operate, including all information on the proposed new permittee, and 2. Include the applicable fee established in 18 A.A.C. 14.

\section{R18-9-710. Reclaimed Water General Permit Revocation}

A. The Director may revoke a Reclaimed Water General Permit if the permittee fails to comply with any requirement in this Article, including a condition specified in the applicable Reclaimed Water General Permit. The Director shall make the determination based on the risk to public health and safety or a threat to waters of the state.

1. Before revoking a general permit, the Department shall provide notice to the permittee by certified mail of the Department's intent to revoke the Reclaimed Water General Permit. The notice of intent to revoke the general permit shall provide the permittee a reasonable opportunity to correct any noncompliance and specify a time-frame within which the permittee shall achieve compliance.

2. If the permittee fails to correct the noncompliance within the specified time-frame, the Department shall notify the permittee, by certified mail, of the Director's decision to revoke the Reclaimed Water General Permit.

B. The Director shall revoke a Reclaimed Water General Permit for any or all facilities located within a specific geographic area, if, due to a geologic or hydrologic condition, the cumulative effect of the facilities subject to the Reclaimed Water General Permit has violated or will violate a Water Quality Standard established under A.R.S. §§ 49-221 and 49-223.

\section{R18-9-713. Type 2 Reclaimed Water General Permit for Direct Reuse of Class A Reclaimed Water}

A. A Type 2 Reclaimed Water General Permit for the Direct Reuse of Class A Reclaimed Water allows any direct reuse application of reclaimed water listed in 18 A.A.C. 11, Article 3, Appendix A, if the conditions in this Article are met.

B. Records and reporting. A permittee shall:

1. Maintain records containing the following information for five years, and make them available to the Department upon request:

a. The direct reuse site,

b. The volume of reclaimed water applied monthly for each category of direct reuse activity listed in 18 A.A.C. 11, Article 3, Appendix A,

c. The total nitrogen concentration of the reclaimed water applied, and

$\mathrm{d}$. The acreage and type of vegetation to which the reclaimed water is applied.

2. Report annually to the Department on or before the anniversary date of the Notice of Intent:

a. The volume of reclaimed water received,

b. The type of reclaimed water application, and

c. If used for irrigation, the vegetation and acreage irrigated.

C. Nitrogen management. A permittee shall ensure that:

1. Impoundments storing reclaimed water allowed by the general permit are lined using a low-hydraulic conductivity artificial or site-specific liner material achieving a calculated discharge rate less than 550 gallons per acre per day; and

2. The application rates of the reclaimed water are based on one of the following:

a. The water allotment assigned by the Arizona Department of Water Resources;

b. A water balance that considers consumptive use of water by the crop, turf, or landscape vegetation; or c. An alternative method approved by the Department.

D. In addition to the Notice of Intent for Direct Reuse of Reclaimed Water specified in R18-9-708(B)(2), the applicant shall provide a list of impoundments and the liner characteristics and the method chosen from the list in subsection $(\mathrm{C})(2)$.

E. The permittee shall post signs as specified in R18-9-704(H).

\section{R18-9-714. Type 2 Reclaimed Water General Permit for Direct Reuse of Class B+ Reclaimed Water}

A. A Type 2 Reclaimed Water General Permit for Direct Reuse of Class B+ Reclaimed Water allows any direct reuse application of Class B and Class $C$ reclaimed water listed in 18 A.A.C. 11, Article 3, Appendix A, if the conditions in this Article are met.

B. A permittee shall comply with the record maintenance and posting requirements established under R18-9-712 and make records available to the Department upon request.

C. No lining is required for an impoundment storing Class B+ reclaimed water. 
R18-9-715. Type 2 Reclaimed Water General Permit for Direct Reuse of Class B Reclaimed Water

A. A Type 2 Reclaimed Water General Permit for the Direct Reuse of Class B Reclaimed Water allows the direct reuse application of Class B and Class $\mathrm{C}$ reclaimed water listed in 18 A.A.C. 11, Article 3, Appendix A, if conditions in this Article are met.

B. A permittee shall comply with the requirements established under R18-9-713(B), (C), (D), and (E).

R18-9-716. Type 2 Reclaimed Water General Permit for Direct Reuse of Class $C$ Reclaimed Water

A. A Type 2 Reclaimed Water General Permit for the Direct Reuse of Class C Reclaimed Water allows the direct reuse application of Class $\mathrm{C}$ reclaimed water listed in 18 A.A.C. 11, Article 3, Appendix A, if conditions in this Article are met.

B. A permittee shall comply with the requirements established under R18-9-713(B), (C), (D), and (E).

\section{R18-9-720. Enforcement and Penalties}

Any person who violates a condition specified in a permit issued under this Article, falsifies data or information submitted to the Department as required under Articles 6 or 7 of this Chapter, or violates a provision of Article 6 or 7 of this Chapter, is subject to the enforcement actions prescribed under A.R.S. §§ 49-261 and 49-262.

\section{ARTICLE 3. RECLAIMED WATER QUALITY STANDARDS}

\section{R18-11-301. Definitions}

The terms in this Article have the following meanings:

"Direct reuse" has the meaning prescribed in R18-9-701(1).

"Disinfection" means a treatment process that uses oxidants, ultraviolet light, or other agents to kill or inactivate pathogenic organisms in wastewater.

"Filtration" means a treatment process that removes particulate matter from wastewater by passage through porous media.

"Gray water" means wastewater, collected separately from a sewage flow, that originates from a clothes washer, bathtub, shower, or sink, but it does not include wastewater from a kitchen sink, dishwasher, or a toilet.

"Industrial wastewater" means wastewater generated from an industrial process.

"Landscape impoundment" means a manmade lake, pond, or impoundment of reclaimed water where swimming, wading, boating, fishing, and other water-based recreational activities are prohibited. A landscape impoundment is created for storage, landscaping, or for aesthetic purposes only.

"NTU" means nepholometric turbidity unit.

"On-site wastewater treatment facility" has the meaning prescribed in A.R.S. § 49-201(24).

"Open access" means that access to reclaimed water by the general public is uncontrolled.

"Reclaimed water" has the meaning prescribed in A.R.S. § 49-201(31).

"Recreational impoundment" means a manmade lake, pond, or impoundment of reclaimed water where boating or fishing is an intended use of the impoundment. Swimming and other full-body recreation activities (for example, water-skiing) are prohibited in a recreational impoundment.

"Restricted access" means that access to reclaimed water by the general public is controlled.

"Secondary treatment" means a biological treatment process that achieves the minimum level of effluent quality defined by the federal secondary treatment regulation at 40 CFR § 133.102.

"Sewage" means untreated wastes from toilets, baths, sinks, lavatories, laundries, and other plumbing fixtures in places of human habitation, employment, or recreation.

\section{R18-11-302. Applicability}

This Article applies to the direct reuse of reclaimed water, except for:

1. The direct reuse of gray water, or

2. The direct reuse of reclaimed water from an onsite wastewater treatment facility regulated by a general Aquifer Protection Permit under 18 A.A.C. 9, Article 3.

R18-11-303. Class A+ Reclaimed Water

A. Class A+ reclaimed water is wastewater that has undergone secondary treatment, filtration, nitrogen removal treatment, and disinfection. Chemical feed facilities to add coagulants or polymers are required to ensure that filtered effluent before disinfection complies with the 24-hour average turbidity criterion prescribed in subsection (B)(1). Chemical feed facilities may remain idle if the 24-hour average turbidity criterion in (B)(1) is achieved without chemical addition.

B. An owner of a facility shall ensure that:

1. The turbidity of Class A+ reclaimed water at a point in the wastewater treatment process after filtration and immediately before disinfection complies with the following: 


\section{Use of Reclaimed Water for Power Plant Cooling Page 49 of 60}

a. The 24-hour average turbidity of filtered effluent is two NTUs or less, and

b. The turbidity of filtered effluent does not exceed five NTUs at any time.

2. Class A+ reclaimed water meets the following criteria after disinfection treatment and before discharge to a reclaimed water distribution system:

a. There are no detectable fecal coliform organisms in four of the last seven daily reclaimed water samples taken, and

b. The single sample maximum concentration of fecal coliform organisms in a reclaimed water sample is less than 23 / $100 \mathrm{ml}$.

c. If alternative treatment processes or alternative turbidity criteria are used, or reclaimed water is blended with other water to produce Class A+ reclaimed water under subsection (C), there are no detectable enteric virus in four of the last seven monthly reclaimed water samples taken.

3. The 5-sample geometric mean concentration of total nitrogen in a reclaimed water sample is less than 10 $\mathrm{mg} / \mathrm{L}$.

C. An owner of a facility may use alternative treatment methods other than those required by subsection (A), or comply with alternative turbidity criteria other than those required by subsection (B)(1), or blend reclaimed water with other water to produce Class A+ reclaimed water provided the owner demonstrates through pilot plant testing, existing water quality data, or other means that the alternative treatment methods, alternative turbidity criteria, or blending reliably produces a reclaimed water that meets the disinfection criteria in subsection (B)(2) and the total nitrogen criteria in subsection (B)(3) before discharge to a reclaimed water distribution system.

D. Class A+reclaimed water is not required for any type of direct reuse. A person may use Class A+ reclaimed water for any type of direct reuse listed in Table A.

\section{R18-11-304. Class A Reclaimed Water}

A. Class A reclaimed water is wastewater that has undergone secondary treatment, filtration, and disinfection. Chemical feed facilities to add coagulants or polymers are required to ensure that filtered effluent before disinfection complies with the 24-hour average turbidity criterion prescribed in subsection (B)(1). Chemical feed facilities may remain idle if the 24-hour average turbidity criterion in subsection (B)(1) is achieved without chemical addition.

B. An owner of a facility shall ensure that:

1. The turbidity of Class A reclaimed water at a point in the wastewater treatment process after filtration and immediately before disinfection complies with the following:

a. The 24-hour average turbidity of filtered effluent is two NTUs or less, and

b. The turbidity of filtered effluent does not exceed five NTUs at any time.

2. Class A reclaimed water meets the following criteria after disinfection treatment and before discharge to a reclaimed water distribution system:

a. There are no detectable fecal coliform organisms in four of the last seven daily reclaimed water samples taken, and

b. The single sample maximum concentration of fecal coliform organisms in a reclaimed water sample is less than 23 / $100 \mathrm{ml}$.

c. If alternative treatment processes or alternative turbidity criteria are used, or reclaimed water is blended with other water to produce Class A reclaimed water under subsection (C), there are no detectable enteric virus in four of the last seven monthly reclaimed water samples taken.

C. An owner of a facility may use alternative treatment methods other than those required by subsection (A), or comply with alternative turbidity criteria other than those required by subsection (B)(1), or blend reclaimed water with other water to produce Class A reclaimed water provided the owner demonstrates through pilot plant testing, existing water quality data, or other means that the alternative treatment methods, alternative turbidity criteria, or blending reliably produces a reclaimed water that meets the disinfection criteria in subsection (B)(2) before discharge to a reclaimed water distribution system.

D. A person shall use Class A reclaimed water for a type of direct reuse listed as Class A in Table A. A person may use Class A reclaimed water for a type of direct reuse listed as Class B or Class C in Table A.

\section{R18-11-305. Class B+ Reclaimed Water}

A. Class B+ reclaimed water is wastewater that has undergone secondary treatment, nitrogen removal treatment, and disinfection.

B. An owner of a facility shall ensure that:

1. Class $\mathrm{B}+$ reclaimed water meets the following criteria after disinfection treatment and before discharge to a reclaimed water distribution system:

a. The concentration of fecal coliform organisms in four of the last seven daily reclaimed water samples is less than 200 / $100 \mathrm{ml}$. 
b. The single sample maximum concentration of fecal coliform organisms in a reclaimed water sample is less than $800 / 100 \mathrm{ml}$.

2. The 5-sample geometric mean concentration of total nitrogen in a reclaimed water sample is less than $10 \mathrm{mg} /$ L.

C. Class B+ reclaimed water is not required for a type of direct reuse. A person may use Class B+ reclaimed water for a type of direct reuse listed as Class B or Class C in Table A. A person shall not use Class B+ reclaimed water for a type of direct reuse listed as Class A in Table A.

\section{R18-11-306. Class B Reclaimed Water}

A. Class B reclaimed water is wastewater that has undergone secondary treatment and disinfection.

B. An owner of a facility shall ensure that Class B reclaimed water meets the following criteria after disinfection treatment and before discharge to a reclaimed water distribution system:

1. The concentration of fecal coliform organisms in four of the last seven daily reclaimed water samples is less than $200 / 100 \mathrm{ml}$.

2. The single sample maximum concentration of fecal coliform organisms in a reclaimed water sample is less than $800 / 100 \mathrm{ml}$.

C. A person shall use a minimum of Class B reclaimed water for a type of direct reuse listed as Class B in Table A. A person may use Class B reclaimed water for a type of direct reuse listed as Class $C$ in Table A. A person shall not use Class B reclaimed water for a type of direct reuse listed as Class A in Table A.

\section{R18-11-307. Class C Reclaimed Water}

A. Class $\mathrm{C}$ reclaimed water is wastewater that has undergone secondary treatment in a series of wastewater stabilization ponds, including aeration, with or without disinfection.

B. The owner of a facility shall ensure that:

1. The total retention time of Class $C$ reclaimed water in wastewater stabilization ponds is at least 20 days.

2. Class $C$ reclaimed water meets the following criteria after treatment and before discharge to a reclaimed water distribution system:

a. The concentration of fecal coliform organisms in four of the last seven reclaimed water samples taken is less than $1000 / 100 \mathrm{ml}$.

b. The single sample maximum concentration of fecal coliform organisms in a reclaimed water sample is less than 4000 / $100 \mathrm{ml}$.

C. A person shall use a minimum of Class $C$ reclaimed water for a type of direct reuse listed as Class $C$ in Table A. A person shall not use Class $\mathrm{C}$ reclaimed water for a type of direct reuse listed as Class A or Class B in Table A.

R18-11-308. Industrial Reuse

A. The reclaimed water quality requirements for the following direct reuse applications are industry-specific and shall be determined by the Department on a case-by-case basis in a reclaimed water permit issued by the Department under 18 A.A.C. 9, Article 7:

1. Direct reuse of industrial wastewater containing sewage.

2. Direct reuse of industrial wastewater for the production or processing of any crop used as human or animal food.

B. The Department shall use best professional judgment to determine the reclaimed water quality requirements needed to protect public health and the environment for a type of direct reuse specified in subsection (A).

\section{R18-11-309. Reclaimed Water Quality Standards for an Unlisted Type of Direct Reuse}

A. The Department may prescribe in an individual reclaimed water permit issued under 18 A.A.C. 9, Article 7, reclaimed water quality requirements for a type of direct reuse not listed in Table A. Before permitting a direct reuse of reclaimed water not listed in Table A, the Department shall, using its best professional judgment, determine and require compliance with reclaimed water quality requirements needed to protect public health and the environment.

B. Department may determine that Class $\mathrm{A}+, \mathrm{A}, \mathrm{B}+, \mathrm{B}$, or $\mathrm{C}$ reclaimed water is appropriate for a new type of direct reuse.

C. The Department shall consider the following factors when prescribing reclaimed water quality requirements for a new type of direct reuse:

1. The risk to public health;

2. The degree of public access to the site where the reclaimed water is reused and human exposure to the reclaimed water;

3. The level of treatment necessary to ensure that the reclaimed water is aesthetically acceptable;

4. The level of treatment necessary to prevent nuisance conditions; 
5. Specific water quality requirements for the intended type of direct reuse;

6. The means of application of the reclaimed water;

7. The degree of treatment necessary to avoid a violation of surface water quality standards or aquifer water quality standards;

8. The potential for improper or unintended use of the reclaimed water;

9. The reuse guidelines, criteria, or standards adopted or recommended by the U.S. Environmental Protection Agency or other federal or state agencies that apply to the new type of direct reuse; and

10. Similar wastewater reclamation experience of reclaimed water providers in the United States.

Table A. Minimum Reclaimed Water Quality Requirements for Direct Reuse

\begin{tabular}{|c|c|}
\hline Type of Direct Reuse & $\begin{array}{l}\text { Minimum Class of Reclaimed Water } \\
\text { Required }\end{array}$ \\
\hline Irrigation of food crops & $\mathrm{A}$ \\
\hline Recreational impoundments & A \\
\hline Residential landscape irrigation & $\mathrm{A}$ \\
\hline School ground landscape irrigation & A \\
\hline Open access landscape irrigation & A \\
\hline Toilet and urinal flushing & A \\
\hline Fire protection systems & A \\
\hline Spray irrigation of an orchard or vineyard & A \\
\hline Commercial closed loop air conditioning systems & A \\
\hline $\begin{array}{l}\text { Vehicle and equipment washing (does not include self-service vehicle } \\
\text { washes) }\end{array}$ & A \\
\hline Snowmaking & A \\
\hline Surface irrigation of an orchard or vineyard & B \\
\hline Golf course irrigation & B \\
\hline Restricted access landscape irrigation & B \\
\hline Landscape impoundment & B \\
\hline Dust control & B \\
\hline Soil compaction and similar construction activities & B \\
\hline Pasture for milking animals & B \\
\hline Livestock watering (dairy animals) & B \\
\hline Concrete and cement mixing & B \\
\hline Materials washing and sieving & B \\
\hline Street cleaning & B \\
\hline Pasture for non-dairy animals & C \\
\hline Livestock watering (non-dairy animals) & C \\
\hline Irrigation of sod farms & C \\
\hline Irrigation of fiber, seed, forage, and similar crops & C \\
\hline Silviculture & C \\
\hline
\end{tabular}

Note: Nothing in this Article prevents a wastewater treatment plant from using a higher quality reclaimed water for a type of direct reuse than the minimum class of reclaimed water listed in Table A. For example, a wastewater treatment plant may provide Class A reclaimed water for a type of direct reuse where Class B or Class C reclaimed water is acceptable. 


\title{
Appendix C - Reclaimed Water Regulations for California
}

\author{
TITLE 22. SOCIAL SECURITY \\ DIVISION 4. ENVIRONMENTAL HEALTH \\ CHAPTER 3. WATER RECYCLING CRITERIA \\ ARTICLE 3. USES OF RECYCLED WATER (selected sections)
}

\author{
60306. Use of Recycled Water for Cooling
}

(a) Recycled water used for industrial or commercial cooling or air conditioning that involves the use of a cooling tower, evaporative condenser, spraying or any mechanism that creates a mist shall be a disinfected tertiary recycled water.

(b) Use of recycled water for industrial or commercial cooling or air conditioning that does not involve the use of a cooling tower, evaporative condenser, spraying, or any mechanism that creates a mist shall be at least disinfected secondary-23 recycled water.

(c) Whenever a cooling system, using recycled water in conjunction with an air conditioning facility, utilizes a cooling tower or otherwise creates a mist that could come into contact with employees or members of the public, the cooling system shall comply with the following:

(1) A drift eliminator shall be used whenever the cooling system is in operation.

(2) A chlorine, or other, biocide shall be used to treat the cooling system recirculating water to minimize the growth of Legionella and other micro-organisms

\subsection{Disinfected Tertiary Recycled Water}

"Disinfected tertiary recycled water" means a filtered and subsequently disinfected wastewater that meets the following criteria:

(a) The filtered wastewater has been disinfected by either:

(1) A chlorine disinfection process following filtration that provides a CT (the product of total chlorine residual and modal contact time measured at the same point) value of not less than 450 milligram-minutes per liter at all times with a modal contact time of at least 90 minutes, based on peak dry weather design flow; or

(2) A disinfection process that, when combined with the filtration process, has been demonstrated to inactivate and/or remove 99.999 percent of the plaque-forming units of F-specific bacteriophage MS2, or polio virus in the wastewater. A virus that is at least as resistant to disinfection as polio virus may be used for purposes of the demonstration.

(b) The median concentration of total coliform bacteria measured in the disinfected effluent does not exceed an MPN of 2.2 per 100 milliliters utilizing the bacteriological results of the last seven days for which analyses have been completed and the number of total coliform bacteria does not exceed an MPN of 23 per 100 milliliters in more than one sample in any 30 day period. No sample shall exceed an MPN of 240 total coliform bacteria per 100 milliliters.

\section{Sampling and Analysis}

(a) Disinfected secondary-23, disinfected secondary-2.2, and disinfected tertiary recycled water shall be sampled at least once daily for total coliform bacteria. The samples shall be taken from the disinfected effluent and shall be analyzed by an approved laboratory.

(b) Disinfected tertiary recycled water shall be continuously sampled for turbidity using a continuous turbidity meter and recorder following filtration. Compliance with the daily average operating filter effluent turbidity shall be determined by averaging the levels of recorded turbidity taken at four-hour intervals over a 24-hour period. 
Compliance with turbidity pursuant to section 60301.320(a)(2)(B) and (b)(1) shall be determined using the levels of recorded turbidity taken at intervals of no more than 1.2-hours over a 24-hour period. Should the continuous turbidity meter and recorder fail, grab sampling at a minimum frequency of 1.2-hours may be substituted for a period of up to 24- hours. The results of the daily average turbidity determinations shall be reported quarterly to the regulatory agency.

(c) The producer or supplier of the recycled water shall conduct the sampling required in subsections (a) and (b).

\section{Engineering Report}

(a) No person shall produce or supply reclaimed water for direct reuse from a proposed water reclamation plant unless he files an engineering report.

(b) The report shall be prepared by a properly qualified engineer registered in California and experienced in the field of wastewater treatment, and shall contain a description of the design of the proposed reclamation system. The report shall clearly indicate the means for compliance with these regulations and any other features specified by the regulatory agency.

(c) The report shall contain a contingency plan which will assure that no untreated or inadequately-treated wastewater will be delivered to the use area.

60341. Emergency Storage or Disposal

(a) Where short-term retention or disposal provisions are used as a reliability feature, these shall consist of facilities reserved for the purpose of storing or disposing of untreated or partially treated wastewater for at least a 24-hour period. The facilities shall include all the necessary diversion devices, provisions for odor control, conduits, and pumping and pump back equipment. All of the equipment other than the pump back equipment shall be either independent of the normal power supply or provided with a standby power source.

(b) Where long-term storage or disposal provisions are used as a reliability feature, these shall consist of ponds, reservoirs, percolation areas, downstream sewers leading to other treatment or disposal facilities or any other facilities reserved for the purpose of emergency storage or disposal of untreated or partially treated wastewater. These facilities shall be of sufficient capacity to provide disposal or storage of wastewater for at least 20 days, and shall include all the necessary diversion works, provisions for odor and nuisance control, conduits, and pumping and pump back equipment. All of the equipment other than the pump back equipment shall be either independent of the normal power supply or provided with a standby power source.

(c) Diversion to a less demanding reuse is an acceptable alternative to emergency disposal of partially treated wastewater provided that the quality of the partially treated wastewater is suitable for the less demanding reuse.

(d) Subject to prior approval by the regulatory agency, diversion to a discharge point which requires lesser quality of wastewater is an acceptable alternative to emergency disposal of partially treated wastewater.

(e) Automatically actuated short-term retention or disposal provisions and automatically actuated long-term storage or disposal provisions shall include, in addition to provisions of (a), (b), (c), or

(d) of this section, all the necessary sensors, instruments, valves and other devices to enable fully automatic diversion of untreated or partially treated wastewater to approved emergency storage or disposal in the event of failure of a treatment process and a manual reset to prevent automatic restart until the failure is corrected. 


\section{Appendix D - Reclaimed Water Regulations for Florida - selected portions \\ (Florida Department of Environmental Protection 2007b, available at: http://www.dep.state.fl.us/water/rulesnum.htm\#62-600)}

\section{PART VII INDUSTRIAL USES OF RECLAIMED WATER 62-610.650 Description of System.}

(1) This type of reuse system involves the use of reclaimed water from domestic wastewater sources for cooling water, wash water, or process water at industrial facilities.

(2) Use of treated industrial wastewaters for land application, recycling within the industrial facility, or other reuse or disposal methods is not governed by Chapter 62-610, F.A.C. Reuse or disposal of industrial wastewaters is regulated by the Department's industrial wastewater rules.

(3) The reclaimed water flowing out of the industrial process shall be considered as an industrial wastewater and shall be subject to regulation under Chapters 62-4, 62-302, 62-520, 62-521, 62-522, 62-620, 62-621, 62-650, 62660, 62-670, 62-671, 62-672, and 62-673, F.A.C., except as provided in Rule 62-610.668, F.A.C.

(4) Food Processing. Reclaimed water shall not be used in the manufacture or processing of food or beverage for human consumption where the reclaimed water will be incorporated into or come in contact with the food or beverage product.

Specific Authority 403.051, 403.061, 403.087 FS. Law Implemented 403.021, 403.051, 403.061, 403.062, 403.085, 403.086, 403.087, 403.088 FS.

History-New 4-4-89, Amended 4-2-90, Formerly 17-610.650, Amended 1-9-96.

62-610.652 Waste Treatment, Disinfection, and Monitoring.

(1) Preapplication waste treatment shall result in a reclaimed water that meets secondary treatment and basic disinfection. If required by subsection 62-610.652(5), F.A.C., additional treatment and disinfection shall be provided.

(2) Individual industrial activities or users may have water quality needs which may necessitate treatment beyond the minimum requirements established in this part. The Department shall not regulate these additional treatment and disinfection requirements. These additional treatment and disinfection requirements shall be subject to negotiation between the industry and the supplier of the reclaimed water.

(3) Except as provided in paragraph 62-610.668(2)(d), F.A.C., domestic wastewater treatment or disinfection provided at the industrial facility before reuse of the reclaimed water at the industrial facility shall be subject to domestic wastewater permitting if the treatment or disinfection at the industrial site is needed to meet the minimum treatment and disinfection requirements imposed by this part of Chapter 62-610, F.A.C.

(4) If additional treatment or disinfection is provided at the industrial facility before reuse of the reclaimed water at the industrial facility, and the additional treatment or disinfection is provided only to meet water quality needs of the industry which are more stringent than the minimum requirements imposed by this part, domestic wastewater permitting shall not be needed for the additional treatment or disinfection facilities located at the industrial facility. (5) All requirements of Part III of Chapter 62-610, F.A.C., including minimum system size requirements, shall be met if reclaimed water will be used in open cooling tower applications, except as provided in paragraphs 62610.668(2)(c) or (d), F.A.C.

(6) Monitoring.

(a) Waste treatment limitations shall be met after disinfection and before discharge to system storage or the reuse system.

(b) If high-level disinfection is provided, the total suspended solids limitation shall be met after filtration and before application of the disinfectant.

(c) For facilities that provide reclaimed water for use in open cooling towers, the permittee shall sample the reclaimed water for Cryptosporidium and Giardia. The following requirements shall be met:

1. Sampling shall be conducted at one time during each two-year period. Intervals between sampling shall not exceed two years. This sampling frequency is independent of the treatment plant's capacity.

2. Samples shall be taken from at a point immediately following the disinfection process.

Specific Authority 403.051, 403.061, 403.087 FS. Law Implemented 403.021, 403.051, 403.061, 403.062, 403.085, 403.086, 403.087, 403.088 FS.

History-New 1-9-96, Amended 8-8-99.

62-610.656 Storage Requirements.

(1) System storage ponds shall not be required. 
(2) If system storage facilities are provided at the domestic wastewater treatment facility, the following requirements apply:

(a) Except as provided in paragraph (b) below, requirements for design and operation of system storage facilities shall be as contained in Rule 62-610.414, F.A.C.

(b) If all requirements of Part III of Chapter 62-610, F.A.C., are met, requirements for design and operation of system storage facilities shall be as contained in Rule 62-610.464, F.A.C.

(3) If system storage facilities are provided at the industrial facility, these storage facilities are subject to regulation under the facility's industrial wastewater permit. These system storage facilities located at the industrial facility will not be regulated under Chapter 62-610, F.A.C.

Specific Authority 403.051, 403.061, 403.087 FS. Law Implemented 403.021, 403.051, 403.061, 403.062, 403.085, 403.086, 403.087, 403.088 FS.

History-New 1-9-96, Amended 8-8-99.

62-610.658 Access Control and Advisory Signs.

(1) For all systems, advisory signs shall be posted around the portions of the industrial site in which reclaimed water is used and at the main entrances to the industrial site to notify employees at the industrial site and the public of the nature of the reclaimed water use.

(2) Access control beyond what is normally provided by the industry is not required.

Specific Authority 403.051, 403.061, 403.087 FS. Law Implemented 403.021, 403.051, 403.061, 403.062, 403.085, 403.086, 403.087, 403.088 FS.

History-New 1-9-96.

62-610.660 Cross-Connection Control and Protection of the Reclaimed Water Supply.

(1) No cross-connections to potable water systems shall be allowed.

(2) For all systems, there shall be readily identifiable "non-potable" or "do not drink" notices, marking, or coding on application/distribution facilities and appurtenances.

(3) Protection of Reclaimed Water Supply.

(a) The return of reclaimed water to the reclaimed water distribution system after the reclaimed water has been delivered to an industrial facility is prohibited. This prohibition shall not apply to industrial sites which were using reclaimed water before January 1, 1996, or which were identified as future users of reclaimed water in a complete permit application received by the Department before January 1, 1996.

(b) The permittee shall conduct an evaluation of the potential for cross-connections and backflow to the reclaimed water distribution system. This analysis shall include an evaluation of the types of substances present at the industrial site which could potentially backflow into the reclaimed water system and the risk associated with possible backflow. The applicant shall evaluate the need for backflow prevention devices on the reclaimed water connection to the industrial facility. This analysis shall be included in the engineering report. A backflow prevention device shall be provided on the reclaimed water service connection to the industrial site, unless the evaluation in the engineering report provides reasonable assurances that there is minimal risk of cross-connection or backflow with contamination of the reclaimed water supply. This requirement for backflow prevention devices shall not apply to industrial sites which were using reclaimed water before January 1, 1996 or which were identified as future users of reclaimed water in a complete permit application received by the Department before January 1, 1996.

Specific Authority 403.051, 403.061, 403.087 FS. Law Implemented 403.021, 403.051, 403.061, 403.062, 403.085, 403.086, 403.087, 403.088 FS.

History-New 4-4-89, Amended 4-2-90, Formerly 17-610.660, Amended 1-9-96.

\section{2-610.662 Setback Distances.}

(1) Except as provided in subsections 62-610.662(2), (3), or (4), F.A.C., setback distances from the industrial process or activity to the site property line are not required.

(2) If reclaimed water which meets the requirements of Part II of Chapter 62-610, F.A.C., is used to irrigate landscaped areas on the industrial site, the setback distance requirements in Rule 62-610.421, F.A.C., shall apply. (3) If reclaimed water which meets the requirements of Part III of Chapter 62-610, F.A.C., is used to irrigate landscaped areas on the industrial site, the setback distance requirements in Rule 62-610.471, F.A.C., shall apply. (4) A 300-foot setback distance shall be provided from an open cooling tower that receives reclaimed water to the site property line. If the full requirements of Part III of Chapter 62-610, F.A.C., or of paragraph 62-610.668(2)(d), F.A.C., are met, no setback distance from the cooling tower to the site property line shall be required.

(5) Unless specifically stated otherwise, all setback distances shall be measured horizontally. Specific Authority 403.051, 403.061, 403.087 FS. Law Implemented 403.021, 403.051, 403.061, 403.062, 403.085, 403.086, 403.087, 403.088 FS. 
History-New 1-9-96, Amended 8-8-99.

62-610.668 Cooling Water Applications.

(1) Once-through cooling.

(a) Reclaimed water may be used for once-through cooling.

(b) Setback distances shall be as established in Rule 62-610.662, F.A.C.

(c) Reclaimed water, upon flowing out of the once-through, non-contact, cooling system, that is returned to the domestic wastewater facilities for additional treatment or disposal or reuse, shall be defined to be a "domestic wastewater." This definition is made solely for the purposes of classifying wastewater treatment, reuse, and effluent disposal facilities associated with the domestic wastewater facilities. This definition shall apply only if the sole change to the quality of the reclaimed water during the once-through, non-contact, cooling process is a temperature increase, and conditioning chemicals, other than chlorine and other chemicals accepted by the Department, have not been added to the reclaimed water.

(d) Reclaimed water which has not been disinfected may be used for once-through cooling purposes at industrial facilities if the following conditions are met:

1. The reclaimed water has received at least secondary treatment as defined in subparagraph 62-600.420(1)(b)2., F.A.C.

2. The reclaimed water is conveyed and used in closed systems which are not open to the atmosphere.

3. The reclaimed water is returned to the domestic wastewater treatment facility.

(e) Water used for once-through cooling under the provisions of paragraph 62-610.668(1)(d), F.A.C., shall be considered "reclaimed water" and the use of this water shall be considered "reuse."

(2) Open cooling towers.

(a) Reclaimed water may be used in open cooling towers, if the requirements in paragraphs 62-610.668(2)(b), (c), or

(d), F.A.C., are met.

(b) All requirements of Part III of Chapter 62-610, F.A.C., including minimum system size requirements, shall be met.

(c) As an alternative to the requirements in paragraph 62-610.668(2)(b), F.A.C., all of the following requirements shall apply:

1. Preapplication waste treatment shall result in a reclaimed water that meets secondary treatment and basic disinfection.

2. A 300-foot setback distance shall be provided from the cooling tower that receives reclaimed water to the site property line.

3. The cooling tower shall be designed and operated to minimize aerosol drift to areas beyond the site property line that are accessible to the public.

4. The cooling tower shall be designed, operated, and maintained utilizing best engineering practices to control biological growth.

(d) As an alternative to the requirements in paragraph 62-610.668(2)(b), F.A.C., all of the following requirements shall be met in the facility's industrial wastewater permit:

1. The high-level disinfection requirements of subsection 62-600.440(5), F.A.C.

2. The filtration requirements of subsection 62-610.460(3), F.A.C.

3. The continuous monitoring requirements of subsection 62-610.463(2), F.A.C.

4. In lieu of the operation, staffing, and reliability provisions in Rule 62-610.462, F.A.C., operation, maintenance, staffing and reliability requirements shall be addressed in the facility's industrial wastewater permit in accordance with applicable industrial wastewater rules.

5. The cooling tower shall be designed, operated, and maintained utilizing best engineering practices to control biological growth.

Specific Authority 403.051, 403.061, 403.087 FS. Law Implemented 403.021, 403.051, 403.061, 403.062, 403.085, 403.086, 403.087, 403.088 FS.

History-New 1-9-96, Amended 8-8-99.

\section{2-610.669 Use of Reclaimed Water at Wastewater Treatment Plants.}

(1) For purposes of this rule, a domestic wastewater treatment plant shall be considered a type of "industrial site." Reclaimed water or partially treated wastewater used for various useful purposes at a domestic wastewater treatment plant shall retain its identity as a domestic reclaimed water or domestic wastewater.

(2) Reclaimed water may be used to irrigate landscaped areas at the wastewater treatment plant.

(a) If the reclaimed water has received secondary treatment and basic disinfection, the requirements of Part II of this

chapter, including setback distance requirements, shall be met. Reclaimed water meeting the secondary treatment 
definition contained in subparagraph 62-600.420(1)(b)2., F.A.C., may be used for this irrigation. Storage shall not be required.

(b) If the reclaimed water meets the treatment and disinfection requirements in Part III of this chapter, the irrigation shall be regulated under Part III.

(3) Reclaimed water may be used for process, wash down, or other purposes at the wastewater treatment plant.

(4) Reclaimed water may be used for toilet flushing or fire protection purposes at the wastewater treatment plant.

(5) Uses of reclaimed water described in subsection 62-610.669(2) through (4), F.A.C., shall be considered as reuse.

(6) Partially treated or undisinfected wastewater may be used for process water or other purposes at the wastewater treatment plant if the wastewater is collected after use and returned to the wastewater treatment plant for additional treatment or disinfection. Use of partially treated wastewater shall not be classified as reuse, unless the water has received a minimum of secondary treatment as defined in subparagraph 62-600.420(1)(b)2., F.A.C. Water that has received a minimum of secondary treatment as defined in subparagraph 62-600.420(1)(b)2., F.A.C. (with or without disinfection), which is used for a beneficial purpose under this paragraph shall be considered "reclaimed water" and the use shall be considered "reuse." Partially treated wastewater which does not meet the minimum treatment and disinfection criteria established in Chapter 62-600 and 62-610, F.A.C., shall not be released to the environment. Specific Authority 403.051, 403.061, 403.087 FS. Law Implemented 403.021, 403.051, 403.061, 403.062, 403.085, 403.086, 403.087, 403.088 FS.

History-New 1-9-96.

62-610.670 Industrial Discharge Limitations.

(1) Disposal or reuse of industrial wastewater resulting from the use of reclaimed water or other water sources in industrial processes shall be subject to Department regulation under the industrial wastewater program. Chapter 62650, F.A.C., and Department rules governing industrial wastewater, as contained in Chapters 62-4, 62-302, 62-520, 62-521, 62-522, 62-620, 62-621, 62-650, 62-660, 62-670, 62-671, 62-672, and 62-673, F.A.C., shall apply.

(2) Reclaimed water used for once-through cooling shall have effluent discharge limitations for surface water discharge established by Section 403.086(4), F.S., if all the following conditions are met:

(a) The reclaimed water delivered to the industrial site meets the requirements contained in Section 403.086(4), F.S.

(b) The discharge to surface water is located within the geographic area defined in Section 403.086(1)(c), F.S.

(c) The only change to the quality of the reclaimed water during the once-through, non-contact, cooling process is a temperature increase.

(d) Conditioning chemicals, other than chlorine and other chemicals accepted by the Department, have not been added.

(e) Department rules governing thermal discharges in Rule 62-302.520 and paragraph 62-620.106(1)(f), F.A.C., will apply at the discharge point.

Specific Authority 403.051, 403.061, 403.087 FS. Law Implemented 403.021, 403.051, 403.061, 403.062, 403.085, 403.086, 403.087, 403.088 FS.

History-New 4-4-89, Formerly 17-610.670, Amended 1-9-96. 


\section{Appendix E - Reclaimed Water Regulations for Texas - selected portions \\ (Texas Administrative Code undated, available at: \\ http://info.sos.state.tx.us/pls/pub/readtac\$ext.ViewTAC?tac_view=4\&ti=30\&pt=1\&ch=210)}

Rule 210.22 - General Requirements

(a) Reuse of untreated wastewater is prohibited.

(b) Food crops that may be consumed raw by humans shall not be spray irrigated. Food crops including orchard crops that will be substantially processed prior to human consumption may be spray irrigated. Other types of irrigation that avoid contact of reclaimed water with edible portions of food crops are acceptable.

(c) There shall be no nuisance conditions resulting from the distribution, the use, and/or storage of reclaimed water.

(d) Reclaimed water shall not be utilized in a way that degrades ground water quality to a degree adversely affecting its actual or potential uses.

(e) Reclaimed water managed in ponds for storage must be prevented from discharge into waters in the state, except for discharges directly resulting from rainfall events or in accordance with a permit issued by the commission. All other discharges are unauthorized. If any unauthorized overflow of a holding pond occurs causing discharge into or adjacent to waters in the state, the user or provider, as appropriate, shall report the noncompliance. A written submission of such information shall also be provided to the TNRCC regional office and to the Austin Office, Water Enforcement Section (MC-149), within five working days of becoming aware of the overflow. The written submission shall contain a description of the noncompliance and its cause; the potential danger to human health or safety, or the environment; the period of noncompliance, including exact dates and times; if the noncompliance has not been corrected, the anticipated time it is expected to continue; and steps taken or planned to reduce, eliminate, and prevent recurrence of the noncompliance, and to mitigate its adverse effects.

Rule 210.32 - Specific Uses of Reclaimed Water

Numerical parameter limits pertaining to specific reclaimed water use categories are contained in $\S 210.33$ of this title (relating to Quality Standards for Using Reclaimed Water). These limits apply to reclaimed water before discharge to initial holding ponds or a reclaimed water distribution system. It shall be the responsibility of the reclaimed water producer to establish that the reclaimed water meets the quality limits at the sample point for the intended use in accordance with the monitoring requirements identified in §210.34 of this title (relating to Sampling and Analysis).

(1) Type I Reclaimed Water Use. This type of use includes irrigation or other uses in areas where the public may be present during the time when irrigation takes place or other uses where the public may come in contact with the reclaimed water. The following types of uses would be considered Type I uses:

(A) Residential irrigation, including landscape irrigation at individual homes.

(B) Urban uses, including irrigation of public parks, golf courses with unrestricted public access, school yards, or athletic fields.

(C) Use of reclaimed water for fire protection, either in internal sprinkler systems or external fire hydrants.

(D) Irrigation of food crops where the applied reclaimed water may have direct contact with the edible part of the crop, unless the food crop undergoes a pasteurization process.

(E) Irrigation of pastures for milking animals.

(F) Maintenance of impoundments or natural water bodies where recreational activities, such as wading or

fishing, are anticipated even though the water body was not specifically designed for such a use.

(G) Toilet or urinal flush water.

(H) Other similar activities where the potential for unintentional human exposure may occur.

(2) Type II Reclaimed Water Use. This type of use includes irrigation or other uses in areas where the public is not present during the time when irrigation activities occur or other uses where the public would not come in contact with the reclaimed water. The following are examples of uses that would be considered Type II uses.

(A) Irrigation of sod farms, silviculture, limited access highway rights of way, and other areas where human access is restricted or unlikely to occur. The restriction of access to areas under irrigation with reclaimed water could include the following:

(i) The irrigation site is considered to be remote.

(ii) The irrigation site is bordered by walls or fences and access to the site is controlled by the owner/operator of the irrigation site. 
(iii) The irrigation site is not used by the public during the times when irrigation operations are in progress. Such sites may include golf courses, cemeteries, and landscaped areas surrounding commercial or industrial complexes. The "syringing" or "wetting" of greens and tees on golf courses shall be allowable under Type II so long as the "syringing" is done with hand-held hoses as opposed to automatic irrigation equipment. The public need not be excluded from areas where irrigation is not taking place. For example, irrigation of golf course fairways at night would not prohibit the use of club house or other facilities located a sufficient distance from the irrigation.

(iv) The irrigation site is restricted from public access by local ordinance or law with specific standards to achieve such a purpose.

(B) Irrigation of food crops where the reclaimed water is not likely to have direct contact with the edible part of the crop, or where the food crop undergoes pasteurization prior to distribution for consumption.

(C) Irrigation of animal feed crops other than pasture for milking animals.

(D) Maintenance of impoundments or natural water bodies where direct human contact is not likely.

(E) Soil compaction or dust control in construction areas where application procedures minimize aerosol drift to public areas.

(F) Cooling tower makeup water. Use for cooling towers which produce significant aerosols adjacent to public access areas may have special requirements.

(G) Irrigation or other non-potable uses of reclaimed water at a wastewater treatment facility.

(3) Any Type I reclaimed water may also be utilized for any of the Type II uses identified in subsection (b) of this section.

\section{Rule 210.33 - Quality Standards for Using Reclaimed Water}

The following conditions apply to the types of uses of reclaimed water. At a minimum, the reclaimed water producer shall only transfer reclaimed water of the following quality as described for each type of specific use:

(1) for Type I reclaimed water uses, reclaimed water on a 30-day average shall have a quality of:

BOD or CBOD - $5 \mathrm{mg} / \mathrm{l}$;

Turbidity - 3 NTU;

Fecal coliform - $20 \mathrm{CFU} / 100 \mathrm{ml}$ geometric mean and $75 \mathrm{CFU} / 100 \mathrm{ml}$ in any grab sample

(2) for Type II reclaimed water use, reclaimed water on a 30-day average shall have a quality of:

(A) for a system other than pond system:

BOD - $20 \mathrm{mg} / \mathrm{l}$ or CBOD - $15 \mathrm{mg} / \mathrm{l}$;

Fecal coliform - $200 \mathrm{CFU} / 100 \mathrm{ml}$ geometric mean and $800 \mathrm{CFU} / 100 \mathrm{ml}$ in any grab sample

(B) for a pond system:

BOD - $30 \mathrm{mg} / \mathrm{l}$;

Fecal coliform - $200 \mathrm{CFU} / 100 \mathrm{ml}$ geometric mean and $800 \mathrm{CFU} / 100 \mathrm{ml}$ in any grab sample

Rule 210.34 - Sampling and Analysis

The reclaimed water producer shall sample the reclaimed water prior to distribution to a user to assure that the water quality is in accord with the intended contracted use. Analytical methods shall be in accord with those specified in Chapter 319 of this title (relating to Monitoring and Reporting). The minimum sampling and analysis frequency for reclaimed water for the applicable parameters identified in §210.33 of this title (relating to Quality Standards for the Use of Reclaimed Water) is as follows:

(1) Type I Reclaimed Water Uses twice per week.

(2) Type II Reclaimed Water Uses once per week. 
Argonne

Environmental Science Division

Argonne National Laboratory

9700 South Cass Avenue, Bldg. 900

Argonne, IL 60439-4832

www.anl.gov

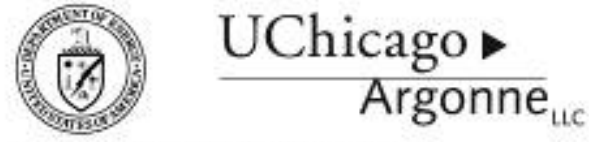

A U.S. Department of Energy laboratory managed by UChicago Argonne, LLC 